



\section{TERRESTRIAL VERTEBRATE BIODIVERSITY IN PROTECTED AREAS AND INDIGENOUS TERRITORIES OF THE AMAZON BASIN}

Final Report

October 2020

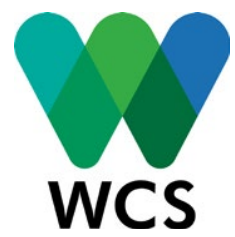


TITLE: TERRESTRIALVERTEBRATE BIODIVERSITY IN PROTECTED AREAS AND INDIGENOUS TERRITORIES OF THE AMAZON BASIN

First Edition: October 2020

Wildlife Conservation Society (WCS)

Authors: Robert Wallace, Omar Torrico, Zulia Porcel \& Enrique Domic

Editor: Robert Wallace

Technical writing:

PhD. Robert Wallace -Director of the Greater Madidi-Tambopata Landscape Conservation Program, WCS Bolivia

MSc. Omar Torrico - Head of Biodiversity Monitoring, WCS Bolivia

MSc. Zulia Porcel - Responsible for Biodiversity Monitoring, WCS Bolivia

Lic. Enrique Domic - Responsible for Biodiversity Monitoring, WCS Bolivia

Cover Photograph: Omar Torrico/WCS

Photograph credits by page:

Rob Wallace/WCS: 1, 2-3, 5,6,16,18-19, 23, 24-25, 27, 32, 35, 41, 44-45, 50, 55, 61, 64-65

Omar Torrico/WCS: 8, 10-11, 12-13, 14, 28, 31, 36-37, 38, 52, 59, 62-63, 66-67

Design: Omar Torrico

For the production of these analyses we are especially grateful for the kind provision of species distribution data from the International Union for the Conservation of Nature (IUCN) Red List Data (Version 2019-1) for amphibians and mammals, BirdLife International for birds, and the Tel Aviv University (Department of Geography) for use of global reptile distributions. We would also like to acknowledge AmphibiaWeb, Reptile Database and the South American Classification Committee for additional information on amphibians, reptiles and birds, respectively.

Suggested citation: Wallace, R., Torrico, 0., Porcel, Z. \& Domic, E. 2020. Terrestrial Vertebrate Biodiversity in Protected Areas and Indigenous Territories of the Amazon Basin. WCS. La Paz, Bolivia.

ISBN: 978-99974-925-9-3

Printed in Bolivia 


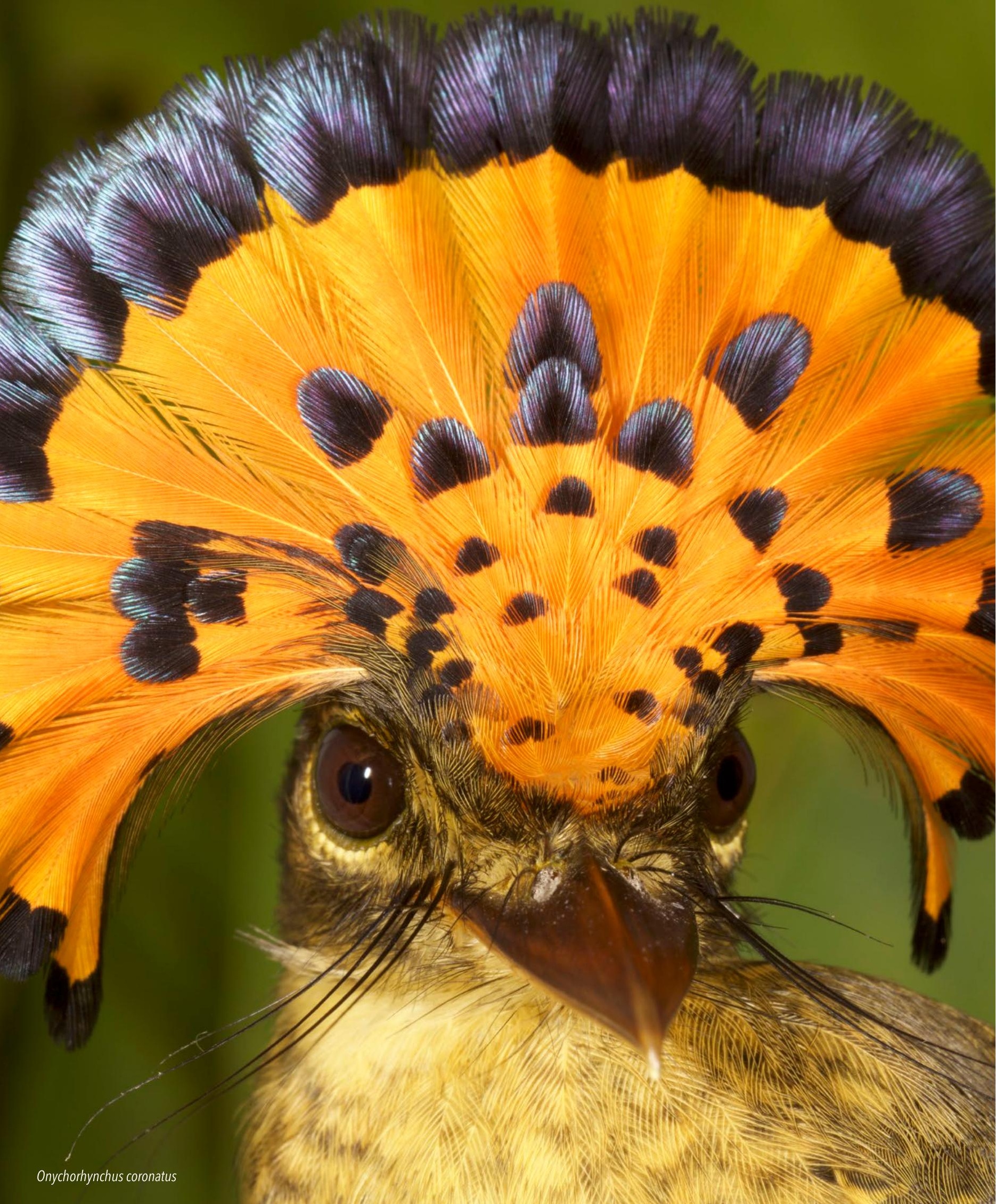




\section{Contents}

ABSTRACT.

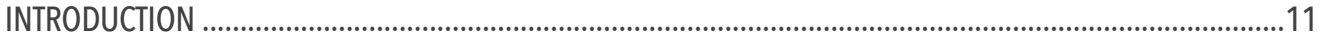

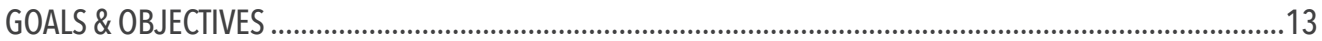

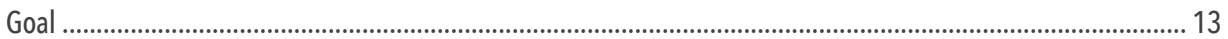

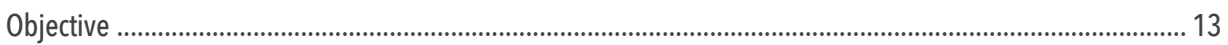

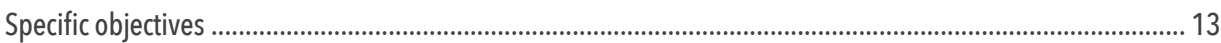

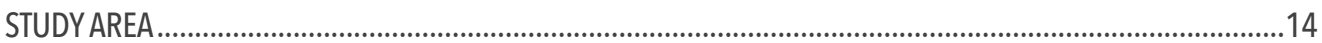

METHODS

Taxonomic revision and update for amphibians, reptiles, birds and mammals............................................. 16

Identification and taxonomic update of terrestrial vertebrate species in the Amazon basin and creation of

distribution polygons for additional amphibians, reptiles and mammals...................................................... 17

Analysis of alpha, beta, gamma diversity in the Amazon basin ......................................................................... 17

i. Alpha-diversity species preliminary analysis for South America and Amazon basin ................................. 17

ii. Analysis of beta and gamma diversity at the level of the Amazon basin ……........................................ 20

Contributions of Protected Areas and Indigenous Territories towards vertebrate biodiversity conservation in

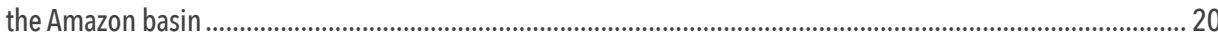

Complementarity analysis for species diversity in the Amazon ....................................................................... 23

RESULTS

Identification and taxonomic update of terrestrial vertebrate species in the Amazon basin and creation of distribution polygons for additional amphibians, reptiles and mammals......................................................... 24

Alpha, beta and gamma diversity analyses for the Amazon basin .................................................................. 24

i. Alpha-diversity species analysis for the Amazon basin ........................................................................ 24

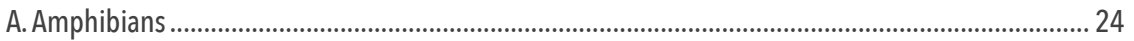

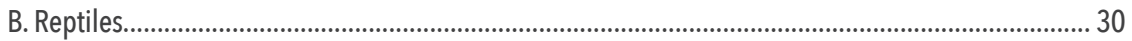


C. Birds

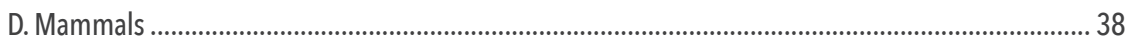

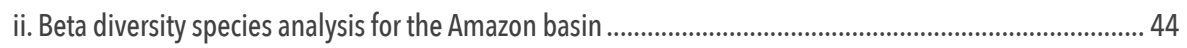

Contribution of protected areas and indigenous territories in the conservation of vertebrates in the Amazon basin

i. Number of expected species for four vertebrate groups in the protected areas and indigenous

territories of the Amazon basin

ii. Representativeness of vertebrate species in Protected Areas and Indigenous Territories in the

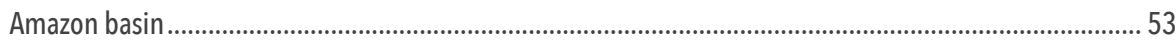

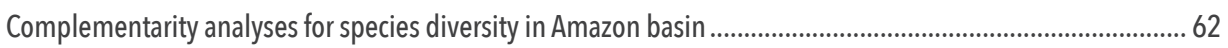

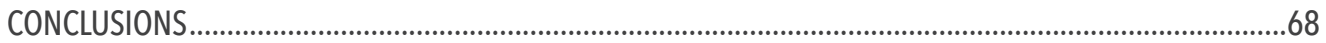

RECOMMENDATIONS FOR FUTURE STUDIES ..........................................................................................

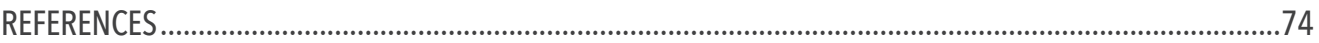

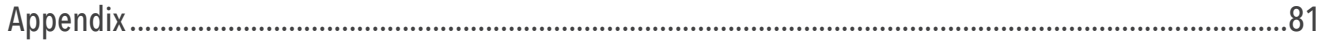




\section{ABSTRACT}

The Amazon is the largest tropical forest in the world, the greatest and most complex freshwater system, and is renowned for extraordinary biodiversity concentrations and significant endemism for different taxonomic groups. The Amazon basin is home to more than 350 indigenous peoples whose rights to land have gradually been recognized by the Amazonian nations over the last 40 years. Indigenous territories and protected areas play an important role in the protection of the Amazon, a hugely important global contribution given that the critical ecosystem services of the Amazon benefit millions of people worldwide.

This study aims to demonstrate the incredible value of the Amazon basin in terms of biodiversity and the contribution of Protected Areas and Indigenous Territories, with emphasis on four groups of terrestrial vertebrates: amphibians, reptiles, birds and mammals. Based on geospatial information on the distribution of amphibian and mammalian species from IUCN and other sources, reptiles from Roll et al. (2017) and birds from BirdLife International, in this second report we estimate the number of expected species in the Amazon basin, and within existing Indigenous Territories and Protected Areas. To determine vertebrate diversity in South America and the Amazon basin, alpha-diversity was analyzed at a $1 \mathrm{~km}^{2}$ scale. Additionally, to assess changes in species composition between sites, beta-diversity was analyzed at different scales within the Amazon basin. Finally, a complementary analysis was performed to determine the degree of similarity and representativeness in vertebrate species composition for the region.

Alpha-diversity analyses revealed a high concentration of amphibian species in the western Amazon (up to 138 species per $\mathrm{km}^{2}$ ), and this group has the lowest representation levels in indigenous territories and protected areas as compared to other terrestrial groups. For reptiles, species concentrations reach up to 184 species per $\mathrm{km}^{2}$ in the Amazon, especially the central north and northwest of the basin. The areas of high concentration of birds in South America are mainly found in the Amazon basin reaching up to 596 species per $\mathrm{km}^{2}$. For mammals, most of the sites with the highest concentration of species are found in the western Amazon, reaching up to 203 species per $\mathrm{km}^{2}$. In all cases many of the species concentrations significantly overlap with the location of the conservation mosaics supported by the Gordon and Betty Moore Foundation. The Gordon and Betty Moore Foundation defines a conservation mosaic as a large landscape composed of protected areas, indigenous territories, and other land use types. This concept is based on an integrated landscape approach adopted by many conservation organizations. Meanwhile, geographic patterns of beta-diversity for amphibians, reptiles, birds and mammals show similar trends at all scales studied, with higher values towards the Andes and intermediate levels in the lowlands.

Collectively, the Protected Areas and Indigenous Territories contribute immensely to the conservation of the four vertebrate groups in the Amazon basin, since these conservation units are expected to harbor 1,188 species of amphibians, 947 species of reptiles, 2,454 species birds and 860 species of mammals: $94.67 \%$ of terrestrial vertebrates 
of the Amazon, $53.91 \%$ of terrestrial vertebrates in South America and $14.92 \%$ of terrestrial vertebrates worldwide. National and Subnational Protected Areas alone are expected to harbor 5,183 species of terrestrial vertebrates $(90.05 \%$ of terrestrial vertebrates in the Amazon, $51.28 \%$ of terrestrial vertebrates in South America and $14.19 \%$ of terrestrial vertebrates worldwide), including 1,058 amphibian species, 893 reptile species, 2,386 bird species and 846 mammal species. Whereas Indigenous Territories are expected to harbor 4,921 terrestrial vertebrate species (85.49\% of terrestrial vertebrates of the Amazon, $48.68 \%$ of terrestrial vertebrates of South America and $13.48 \%$ of terrestrial vertebrates worldwide), including 939 amphibian species, 848 reptile species, 2,334 species of birds and 800 mammal species.

These analyses demonstrate that together Protected Areas and Indigenous Territories are expected to host the majority of terrestrial vertebrates of the Amazon basin, stressing the importance of their management through territorial planning, control and surveillance and effective management. Indeed, to date deforestation levels and environmental degradation rates are significantly lower in Protected Areas and Indigenous Territories than elsewhere in the Amazon. The analysis of representativeness at the country level also reveals that Protected Areas and Indigenous Territories in most Amazonian nations would house more than $70 \%$ of vertebrate species diversity, further underlining that the collective of Protected Areas and Indigenous Territories are located in strategic and efficient conservation sites. However, for amphibians and reptiles there are lower levels of species representativeness in Brazil, Colombia and Ecuador, compared to French Guiana, Peru, Suriname and Bolivia where levels are higher.

The vertebrate complementarity analysis for the Amazon basin shows that of the 254 cells covering this region, an estimated 112 cells would need to be protected to include all $100 \%$ of amphibian species, 87 cells for all reptile species, 66 cellsfor all birds and 46 cellsfor all mammal species. A comparison of the selected complementarity cells for the four vertebrate groups with the National Protected Areas, Subnational Protected Areas and Indigenous Territories in each country, demonstrated that independently the differing management unit categories fail to fully protect these cells, but when combined they manage to protect almost all of the cells, further highlighting their complementarity towards biodiversity conservation in the Amazon. Overall these analyses underline the commitment that Amazonian nations have already made towards biodiversity conservation in the Amazon through the formal designation of Protected Areas across the basin, and the recognition of large areas as Indigenous Territories. Together these conservation friendly management units amount to almost $50 \%$ of the basin and this study demonstrates that most terrestrial vertebrate biodiversity, almost $95 \%$, is expected to occur within at least one of Protected Area or Indigenous Territory.

Key Words: Protected Areas, Indigenous Territories, amphibians, reptiles, mammals, birds, Gordon and Betty Moore Foundation 

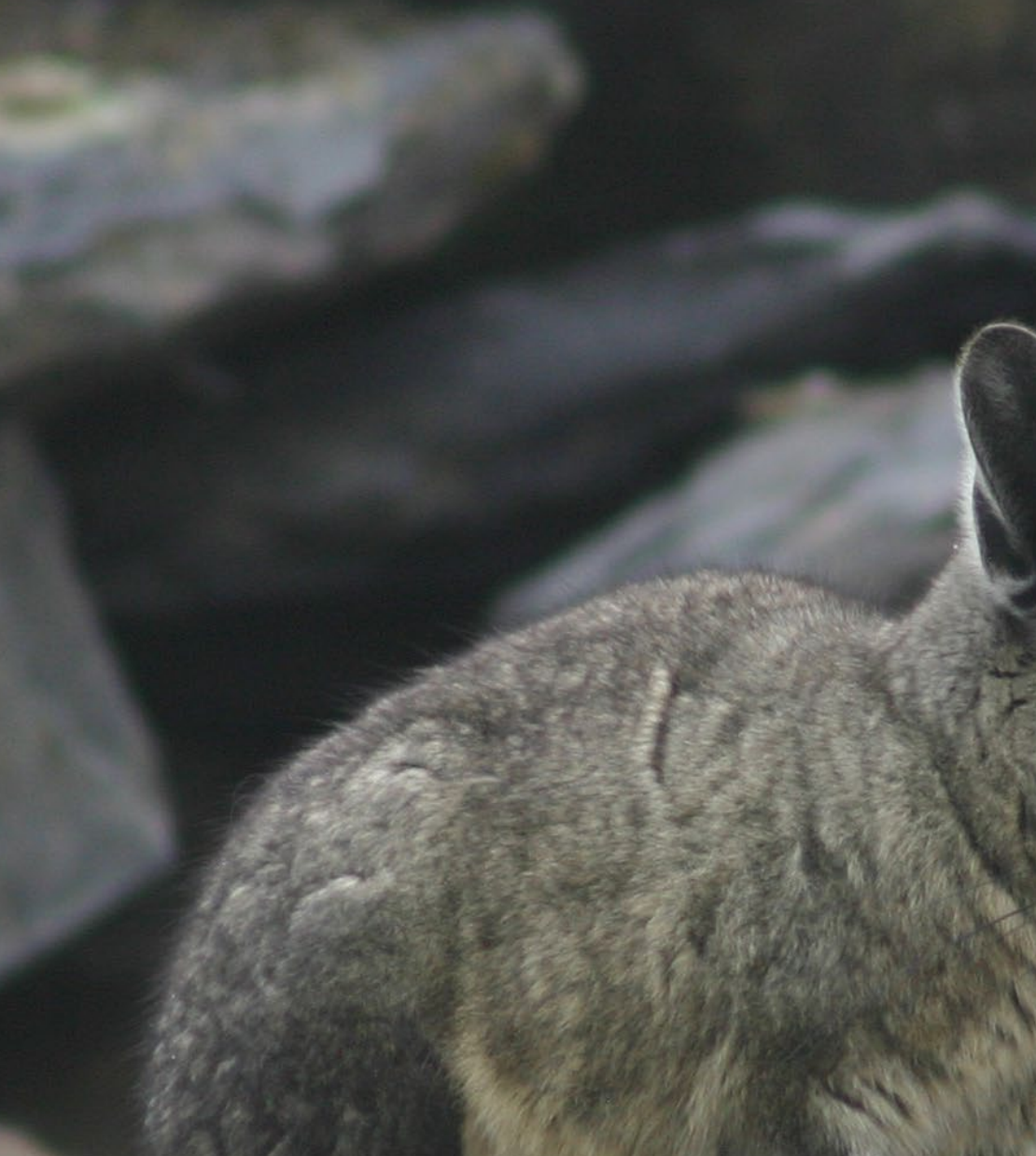

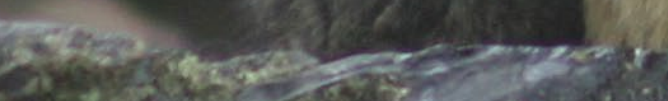

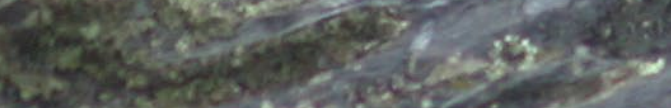

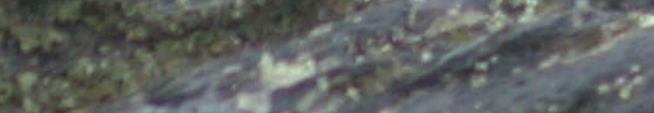
SCE: any 4.

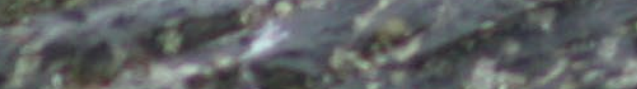

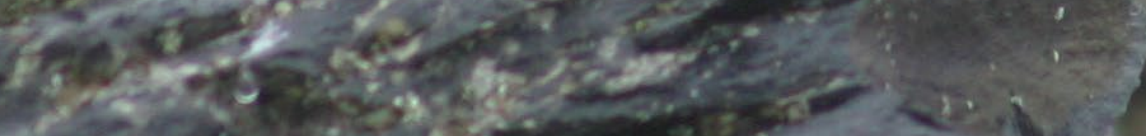

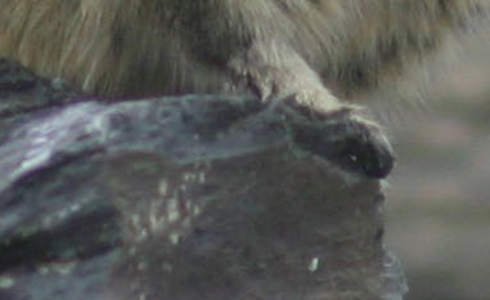

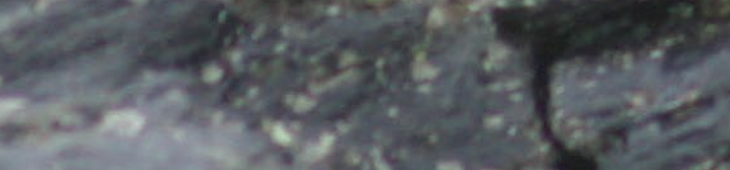
cosinges

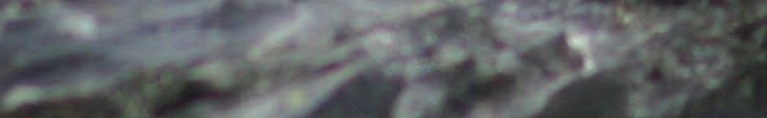
M. 


\section{INTRODUCTION}

Biodiversity or biological diversity are terms that define the variation in all the forms of life on planet earth (Gaston \& Spicer 2004; Colwell 2009). This comprises the appearance, structure and function of genes, species and ecosystems, which are organized in spatial and temporal patterns (Gregorius et al. 2003; Colwell 2009; Minteer et al. 2018). Species diversity, or the number of biological elements coexisting in a given area, is the most commonly used element for conservation purposes (Moreno 2001; Moreno et al. 2011; Socolar et al. 2015).

From a global perspective the tropics harbor the greatest biological diversity and endemism (Myers et al. 2000; Hoorn et al. 2010; Jenkins et al. 2013). The tropics cover just $10 \%$ of land, butharbor $91 \%$ of the world's birds, $83.2 \%$ of amphibians, $77 \%$ of mammals and $75 \%$ of plants and insects (PNUMA 2010; Barlow et al. 2018). The Amazon in the Neotropics has an enormous variety of habitats and aquatic and terrestrial species (Latrubesse et al. 2017). Unique characteristics such as the geographical barrier of the Andes and the variety of forests, wetlands and other habitats have resulted in extremely high levels of biodiversity and endemism in the Amazon (Valencia et al. 1994; Dirzo \& Raven et al. 2003; Hutter et al. 2013; De Oliveira et al. 2016; Kolář et al. 2016).
The extraordinary concentration of species in the Amazon basin is mirrored by a diversity of crucial ecosystem senvices, such as timber, food, water, energy, nutrient recycling, and others (Foley et al. 2007; Tilman et al. 2011; Sobral et al. 2017; Horn et al. 2018), which benefit millions of people (Horn et al. 2018; Minteer et al. 2018; Vieira et al. 2018), providing environmental services not only for the Neotropical region, but also for the world (Castro \& Riega-Campos 2014).

The Amazon basin is also home to approximately 350 indigenous groups whose territories cover $28 \%$ of the basin in Bolivia, Brazil, Colombia, Ecuador, Peru and Venezuela (Prüssmann et al. 2017; Strelneck \& Vilela 2017, RAISG 2019). High human cultural diversity within the indigenous territories (ITs) is associated with high biodiversity concentrations, and together with protected areas (PAs), play an important role in protecting the Amazon biome and the planet (RAISG 2016; Prüssmann et al. 2017; Strelneck \& Vilela 2017). Together, we expect Protected Areas and Indigenous Territories to harbor high levels of biodiversity in the Amazon, given that globally Indigenous Territories (Jonas et al 2014; Schleicher et al. 2017) and Protected Areas (Gray et al. 2016) contain significantly higher levels of biodiversity than areas outside those management units. Nevertheless, comprehensive studies regarding the representativeness and 
effectiveness of ecosystems and biodiversity within Protected Areas or Indigenous Territories are missing (Chape et al. 2006;

González-Maya et al. 2015), especially for the Amazon.

Anthropogenic activities outside conservation units in the Amazon are responsible for the loss of biodiversity at an unprecedented rate (Peres 1990, 2007; Foley et al. 2007; Hoorn et al. 2010; Canale et al. 2012; Laurance et al. 2014; Purvis et al. 2018). In the face of imminent and ongoing changes to Amazon forests and waterways, the need to identify priority biodiversity consenvation is paramount. One approach is to identify areas with high concentration of species and endemism. For example, the "hotspots" proposed by Myers et al. (2000) have become a global conservation reference (Sloan et al. 2014; Roll et al. 2017), encouraging donors such as the Gordon and Betty Moore Foundation to implement conservation efforts in areas of high biodiversity and endemism, in particular with landscape and mosaic conservation strategies in the Amazon and beyond (Myers et al. 2000).

The Gordon and Betty Moore Foundation has implemented an Andes-Amazon Initiative, supporting biodiversity conservation efforts by communities, governmental authorities and nongovernmental institutions for more than fifteen years (Gullison \& Hardner 2018), implementing twelve conservation mosaics distributed in Bolivia, Brazil, Colombia, Ecuador and Peru in areas with hypothesized high biodiversity concentrations (Castro \& Riega-Campos 2014; Strelneck \& Thais Vilela 2017)

For the design of informative scenarios regarding global biodiversity it is important to recognize that biodiversity varies across habitat types, as well as between different taxonomic groups such as amphibians, mammals, insects or plants (Wolters et al. 2006). It is therefore crucial to evaluate multiple taxonomic groups when considering spatial variations in biological diversity, especially when identifying priority conservation areas (Wolters et al. 2006; Quan et al. 2018). Similarly, for the Amazon basin it is crucial to understand to what extent existing conservation units (protected areas and indigenous territories) protect different taxonomic groups to complement our recognition of their global importance towards the mitigation of global climate change.

This study aims to demonstrate the incredible biodiversity value of the Amazon basin and the contribution of twelve conservation mosaics supported by the Gordon and Betty Moore Foundation (Wallace et al. 2020), as well as the effectiveness of existing conservation units (protected areas and indigenous territories) in consenving biodiversity, with an emphasis on the four terrestrial vertebrate groups: amphibians, reptiles, birds and mammals. In so doing, this 
analysis intends to demonstrate the relevance of existing

conservation efforts in the Amazon, as well as influence future

decisions and actions in the conservation mosaics.

The added value of this assessment is that it attempts to project the overall biodiversity presence across the entire Amazon using a consistent approach and dataset. There is also an underlying premise by the conservation community that a protected area is the appropriate management and geographic unit to ensure biodiversity conservation. This assessment is one way of measuring how effective that management can be for biodiversity conservation.

\section{GOALS \& OBJECTIVES}

\section{Goal}

Demonstrate the extraordinary value of the Amazon basin towards biodiversity conservation through analyses of four terrestrial vertebrate groups: amphibians, reptiles, birds and mammals.

\section{Objective}

Demonstrate the contribution of the conservation mosaics in the Amazon basin supported by the Gordon and Betty Moore Foundation, as well as the general importance of the effective management of protected areas and indigenous territories for biodiversity conservation in the Amazon.

\section{Specific objectives}

- Identify the vertebrate species expected to occur within existing protected areas and indigenous territories.

- Identify the most important geographical gaps in biodiversity protection in the Amazon basin.

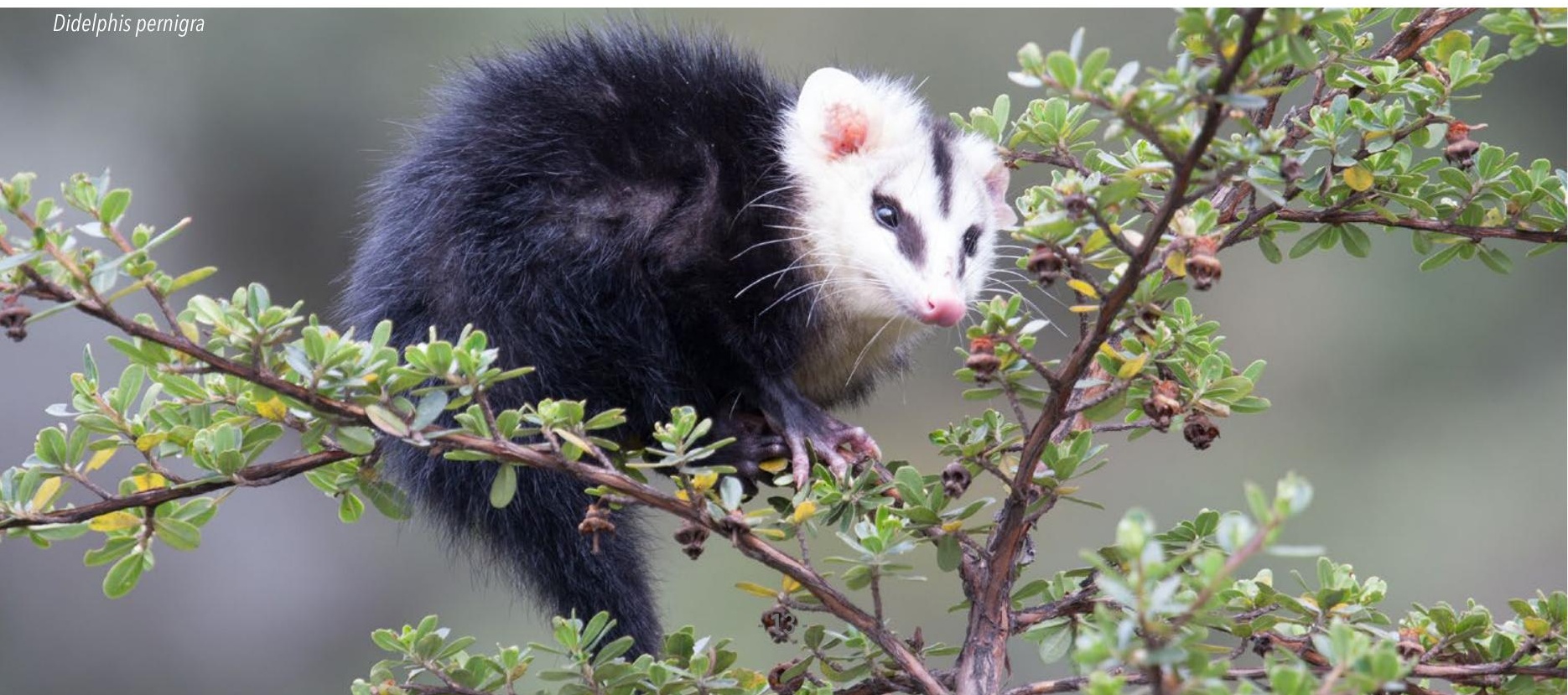




\section{STUDYAREA}

The study area is the Amazon basin, the most extensive tropical

forest and the largest freshwater hydrological system in the

world, with particular emphasis on the conservation mosaics

supported by the Gordon and Betty Moore Foundation (Table

1; Figure 1; Appendix). The Amazon basin is shared by nine

countries (Brazil, Bolivia, Peru, Ecuador, Colombia, Venezuela,

French Guiana, Guyana, and Suriname) and is inhabited by 33

million people including 350 indigenous groups (Prüssmann

et al. 2017). These nine countries hold a total of 610 National

Protected Areas covering $1,984,569 \mathrm{~km}^{2}$ in the Amazon,

with Indigenous Territories covering another 2,368,936 km²

(Walker et al. 2014; RAISG 2019).
Table 1. Conservation Mosaics supported by the Gordon and Betty Moore Foundation in the Amazon Basin

\begin{tabular}{|c|c|}
\hline Mosaic & Countries \\
\hline Chiribiquete-Caqueta & Colombia \\
\hline Yasuni-Pastaza & Ecuador, Peru \\
\hline Yavari-Samiria & Peru \\
\hline Ampiyacu & Peru \\
\hline Upper Purus & Brazil, Peru \\
\hline Madidi-Tambopata & Bolivia, Peru \\
\hline Itenez-Rondonia & Bolivia, Brazil \\
\hline Calha Norte & Brazil \\
\hline Xingu & Brazil \\
\hline Lower Rio Negro & Brazil \\
\hline Upper Rio Negro & Colombia, Brazil \\
\hline Madeira & Brazil \\
\hline
\end{tabular}

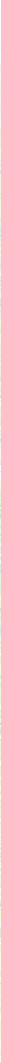




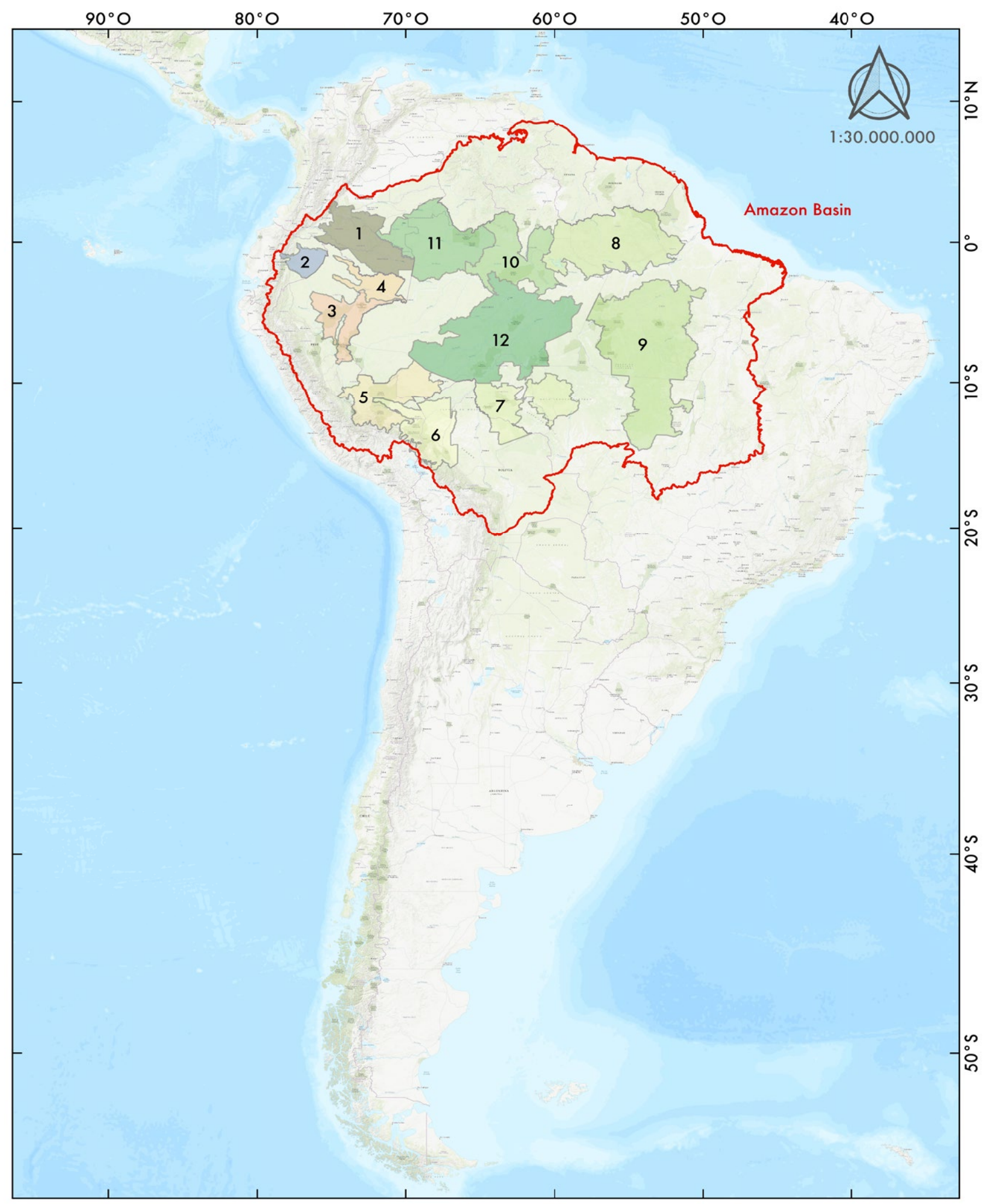

Figure 1: Location of the Conservation Mosaics supported by the Gordon and Betty Moore Foundation in the Amazon Basin. 1. Chiribiquete-Caqueta; 2. Yasuni-Pastaza; 3. Yavari-Samiria; 4. Ampiyacu; 5. Upper Purus; 6. Madidi-Tambopata; 7. Itenez-Rondonia; 8. Calha Norte; 9. Xingu; 10. Lower Rio Negro; 11. Upper Rio Negro; 12. Madeira 
To generate expected species lists for amphibians, reptiles, birds and mammals for the Amazon basin, we performed the following three steps: 1) taxonomic revision and update for terrestrial vertebrate species present in South America and the Amazon basin, 2) taxonomic species update according to the IUCN and Roll et al. (2017) and creation of new distribution polygons for amphibian, reptile and mammal species not evaluated by the IUCN, and 3) identification of expected species for the Amazon basin. This analysis is a fine-scale $1 \mathrm{~km}^{2}$ effort which uses a standardized and updated dataset for all four terrestrial vertebrate groups across the Amazon. It cannot and should not replace on-the-ground field work to improve knowledge for individual protected areas and indigenous territories, but in the meantime, it does provide the best theoretical species lists available for each management unit.

\section{Taxonomic revision and update for amphibians,}

\section{reptiles, birds and mammals}

In order to compare the number of species present in South America and the Amazon basin, we first standardized taxonomic species lists for each terrestrial vertebrate group. For taxonomic updates we used official taxonomic platforms for each vertebrate group: AmphibiaWeb (https://amphibiaweb. org), The Reptile Database (http://www.reptile-database.org), IUCN-BirdLife (http://datazone.birdlife.org/species/requestdis) and South American Classification Committee (http://www. museum.Isu.edu/ Remsen/SACCBaseline.htm) for birds, and Mammal Diversity Database (https://mammaldiversity. org) and specific sources for mammals, as well as a global taxonomic source: the Taxonomic Information System IT IS (https://www.itis.gov). With the exception of mammals, these websites constantly update taxonomy, providing species lists for each country.

Additionally, to determine the taxonomy for amphibians and reptiles we consulted scientific articles and previously cited websites. For mammals firstly we constructed a species list for South America using recent species lists for Ecuador (Tirira 2018; Ron et al. 2019), Colombia (Ramírez-Chaves et al. 2016), Venezuela (Sánchez \& Lew 2012), Argentina (Teta et al. 2018), French Guiana, Guyana, and Suriname (Lim 2016), Brazil (Paglia et al. 2012), and Bolivia (Aguirre et al. 2019) and the IUCN South America species list. We then complemented and updated taxonomies using the Mammal Diversity Database (2019), and Patton et al. (2015) for rodents, Rowe \& Myers (2019) for primates and scientific articles published until December 2018 regarding newly described species. 
Identification and taxonomic update of terrestrial vertebrate species in the Amazon basin and creation of distribution polygons for additional amphibians, reptiles and mammals

Geospatial information on amphibian, reptile and mammal species distributions was downloaded from the IUCN (IUCN 2018, https://www.iucnredlist.org) in November 2018, (reptiles in January 2019 from Roll et al. (2017)), and bird distributions were downloaded from BirdLife International, through the IUCN portal. Scientific names were updated using the updated taxonomic lists.

For amphibian, reptile and mammal species from the Amazon basin that were either not evaluated by the IUCN or were not considered in a threatened category, using scientific literature and webpages, we produced distribution polygons using Quantum GIS. Similarly, for newly described species we created distribution polygons with the geospatial Quantum GIS tool Concave Polygons, creating a $10 \mathrm{~km}$ buffer for species with only 1 or 2 records.
Nevertheless, in some cases, species and even genera, remain in taxonomic revision or require major research to confirm taxonomies, and therefore are lacking distributional polygons, underlining that this analysis will need to be updated into the future.

To finalize geospatial information for amphibians, reptiles and mammals, the new polygons were united with the geospatial information in Table 2, using the Quantum GIS tool Merge.

Analysis of alpha, beta, gamma diversity in the Amazon basin

i. Alpha-diversity species preliminary analysis for South America and Amazon basin

To determine the areas of greatest vertebrate diversity in South America and the Amazon basin we analyzed alpha-diversity. To date global efforts to determine species concentrations have used pixels of $10 \mathrm{~km}^{2}$ or greater (Myers et al. 2000; Jenkins et al. 2013; Roll et al. 2017). Here we use a finer pixel size of $1 \mathrm{~km}^{2}$.

Table 2. Number of Vertebrate Species in South America

\begin{tabular}{|c|c|c|}
\hline Vertebrate Group & Geospatial Source & Number of Species \\
\hline Amphibians & AmphibiaWeb & 2,921 \\
\hline Reptiles & IUCN & 2,474 \\
\hline Birds & Roll et al. (2017) & 1,977 \\
\hline Mammals & BirdLife & 3,564 \\
\hline & IUCN - Birdlife & 3,625 \\
\hline
\end{tabular}


Geospatial information on IUCN species distributions (using the geospatial information in Table 2) was projected on WGS 84/ World Mercator (EPSG:3395). Using the SAGA geoprocessing rasterize tool (Conrad et al. 2015), we generated raster data for each terrestrial vertebrate species using $1 \times 1 \mathrm{~km}$ sized pixels, reclassifying values, where a value of 1 was assigned to pixels with presence, and 0 to those without presence.

Finally, using the geoprocessing raster calculator, we analyzed species distributions as a function of IUCN conservation state: Extinct (EX),

Critically Endangered(CR), Critically Endangered \& Possibly Extinct(CR

PE), Critically Endangered \& Extinct in the Wild (CR EW), Endangered

(EN), Vulnerable (VU), Near Threatened (NT), Least Concern (LC), Data

Deficient (DD) and Not Evaluated. For the alpha-diversity analyses we summed the different conservation status raster's, with the exception of the Extinct and Extinct in the Wild categories. Additionally, using the geospatial information in Table 5 (new polygons) and the Quantum GIS tools Spatial Join and Calculator, we generated the same information in Vector format. The alpha-diversity analysis was only performed in vector format for the Amazon basin, as the amount of information for South America was prohibitive for analysis within this report. 
nom

\section{$+x^{2}$} j. $\stackrel{2}{2}=$

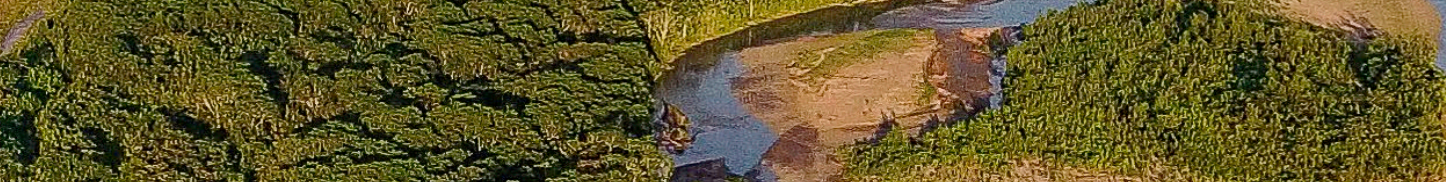

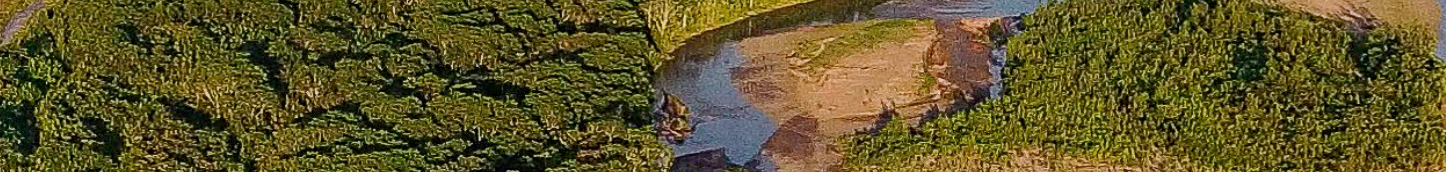
1. 1. 1. कh 党

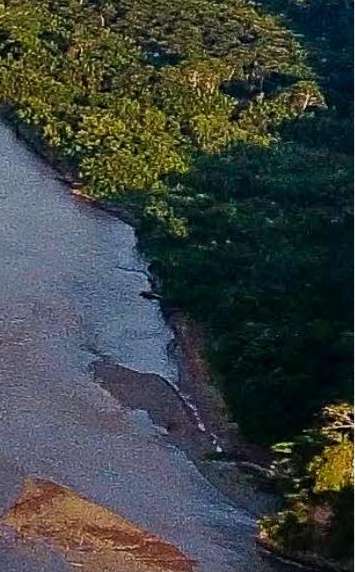

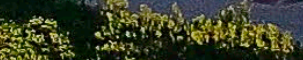

W.

2.

(n)

(1) (2) V. 14t 14.5. 1.1. 1. 6 3.

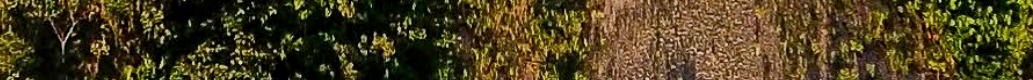
C. (n) 
ii. Analysis of beta and gamma diversity at the level of the

Amazon basin

To demonstrate changes in species composition between sites, we analyzed beta-diversity $(\beta)$ at different spatial scales, using the geospatial data on the distribution of species from the four terrestrial vertebrate groups, following methods proposed by Rodríguez et al. (2019), defining the finest unit of analysis at 1 $\mathrm{km}^{2}$, similar to that of our alpha-diversity analysis. Subsequently, to calculate beta-diversity ( $\beta$ ), we divided the Amazon basin into four different sized grid cells: $2^{\circ} \times 2^{\circ}(\sim 200 \times 200 \mathrm{~km}), 1^{\circ} \times 1(\sim 100 \times$ $100 \mathrm{~km}), 0.5^{\circ} \times 0.5^{\circ}(\sim 50 \times 50 \mathrm{~km})$ and $0.25^{\circ} \times 0.25^{\circ}(\sim 25 \times 25 \mathrm{~km})$.

To estimate beta-diversity ( $\beta$ ), we used the formula $\beta=\gamma /$ mean $\boldsymbol{\alpha}$, where $\gamma$ is gamma-diversity, or, the number of species in the region, and $\alpha$ is alpha-diversity, or, the average number of species at the sites that make up the region. For this study, a region is one of the largest sized cells used to subdivide the Amazon basin. We used beta-diversity $(\beta)$ because it is methodologically independent of alpha and gamma diversity (Baselga 2010; Rodriguez et al. 2019), allowing the comparison between taxa with a different number of species. Beta-diversity ( $\beta$ ) was estimated for each vertebrate group at each spatial scale. Beta-diversity ( $\beta$ ) includes values from 1 , where every species is present in every cell (low beta-diversity). When beta-diversity $(\beta)$ is equal to gamma-diversity $(\gamma)$, every species in the region is only present at one site (greater beta-diversity).
From a comparative perspective, methodologically we considered eliminating cells that were partially outside the limits of the basin. However, this step left only 89 cells and so we elected to retain all 254 cells and consider those on the periphery as cells subject to border effects.

Contributions of Protected Areas and Indigenous Territories towards vertebrate biodiversity conservation in the Amazon basin

Geospatial data for the Amazon basin was downloaded from the SNAPP Western Amazon Group (Venticinque et al. 2016), and international limits from the Global Administrative Areas (GADM 2018) and updated geospatial data on National Protected Areas, Subnational Protected Areas and Indigenous Territories from the Amazon Network of Georeferenced Socio-environmental Information (Red Amazónica de Información Socioambiental Georreferenciada - RAISG) downloaded in May 2019 (Tables 3 \&4).

For each taxonomic group the analysis of expected species in the different conservation units was conducted by combining the Amazon basin limits and the distribution information for possible species (Table 2, from IUCN data), together with new information generated for amphibians, reptiles and mammals (new polygons), using the Quantum GIS tool Intersection. 
Table 3. Protected Area sources for each country as considered by RAISG 2018.

\begin{tabular}{|c|c|c|c|}
\hline Conservation Areas & Country & Source & Year \\
\hline \multirow{12}{*}{ National Protected Areas } & Bolivia & Servicio Nacional de Áreas Protegidas & 2016 \\
\hline & Brazil & Instituto Socioambiental & 2016 \\
\hline & \multirow{3}{*}{ Colombia } & IDEAM & 2012 \\
\hline & & UAESPNN DTAO & 2013 \\
\hline & & UAESPNN DTSA & 2012 \\
\hline & Ecuador & Ministerio del Ambiente (MAE) & 2016 \\
\hline & French Guiana & Direction Régionale de l'Environnement de Guyane & 2010 \\
\hline & Guyana & Ivrokrama;Digital Chart World (DCW) & \\
\hline & Peru & Ministerio del Ambiente & 2016 \\
\hline & Suriname & Amazon Conservation Team (ACT) & 2009 \\
\hline & \multirow{2}{*}{ Venezuela } & Rodriguez et al. & 2014 \\
\hline & & Provita & 2015 \\
\hline \multirow{8}{*}{ Subnational Protected Areas } & \multirow{5}{*}{ Bolivia } & Gobierno Autónomo Departamental de Beni & 2014 \\
\hline & & Gobierno Autónomo Departamental de SCZ & 2013 \\
\hline & & Gobierno Municipal de Ixiamas & 2009 \\
\hline & & Gobierno Autónomo Departamental de Pando & 2013 \\
\hline & & Ministerio de Medio Ambiente y Agua & 2012 \\
\hline & Brazil & Instituto Socioambiental & 2016 \\
\hline & Ecuador & Ministerio del Ambiente (MAE) & 2016 \\
\hline & Peru & Ministerio del Ambiente & 2016 \\
\hline
\end{tabular}

Table 4. Indigenous Territories sources for each country, as considered by RAISG 2018.

\begin{tabular}{|c|c|c|}
\hline Country & Source & Year \\
\hline Bolivia & Sistema Nacional de Información para el Desarollo - SNID & \\
\hline Brazil & Instituto Socioambiental & 2016 \\
\hline Colombia & SIGOT & 2015 \\
\hline Ecuador & MAE & 2012 \\
\hline French Guiana & Direction Régionale de l'Environnement de Guyane & 2007 \\
\hline Guyana & Indigenous Affair/Governo da Guyana & 2009 \\
\hline Peru & Cultura-2016 & 2016 \\
\hline \multirow{7}{*}{ Venezuela } & Ministerio del Poder Popular para la Salud, mapa, & 2007 \\
\hline & OIPUS-OPIJKA-CIAG-UNEG & 2008 \\
\hline & OIPUS-WATANIBA & 2011 \\
\hline & HORONAMI & 2014 \\
\hline & OIPUS-OPUHC-Wataniba-Provita & $2014-2015$ \\
\hline & Proyecto BABA & $2014-2015$ \\
\hline & ISA, HUTUKARA, WATANIBA, Comunidades, Tierra y Hábitat Yanomami Brasil-Venezuela; KUYUJANI, KUYUJANI ORIGINARIO, KUYUNU, WATANIBA, PROVITA & \\
\hline
\end{tabular}



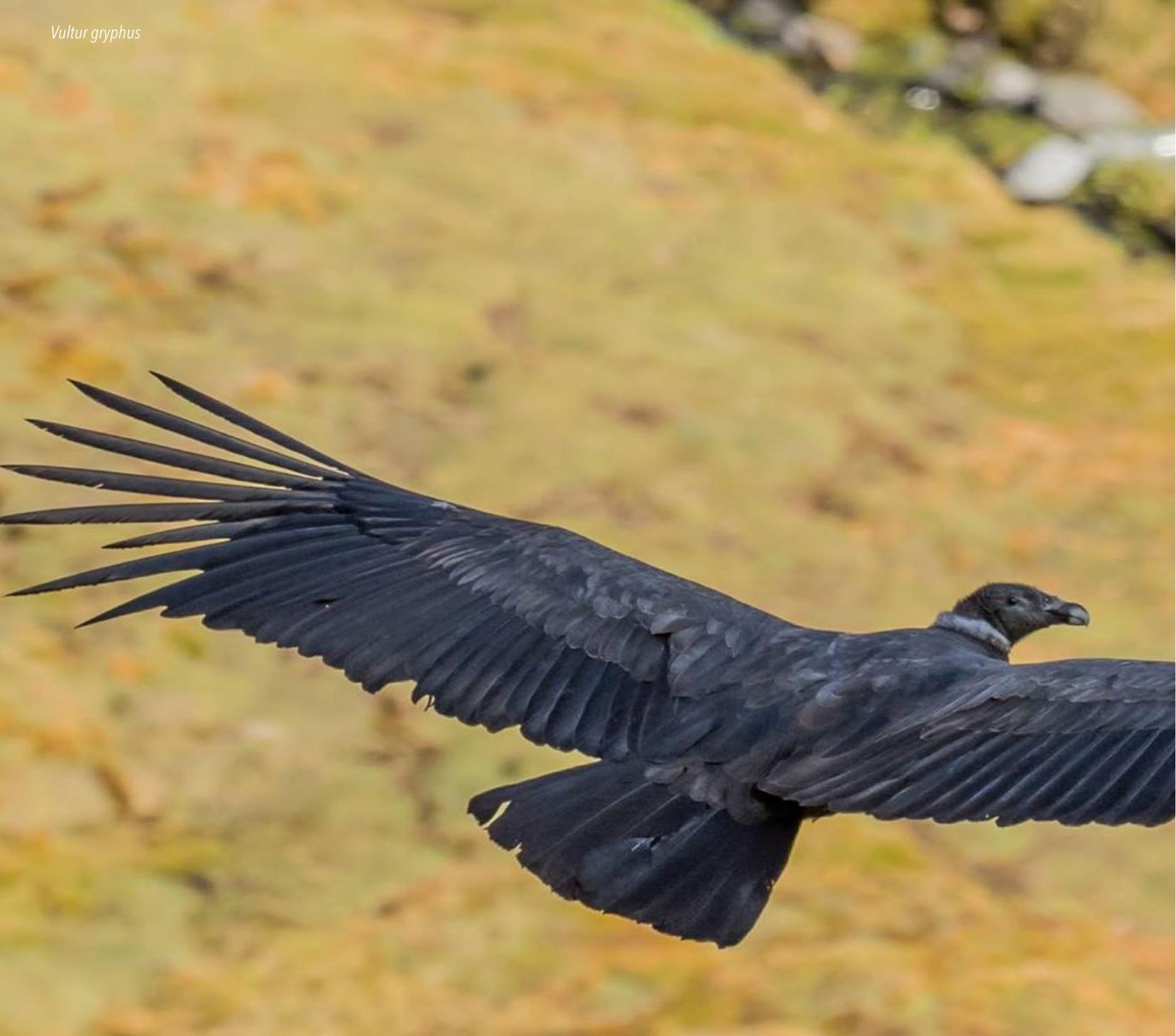

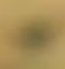
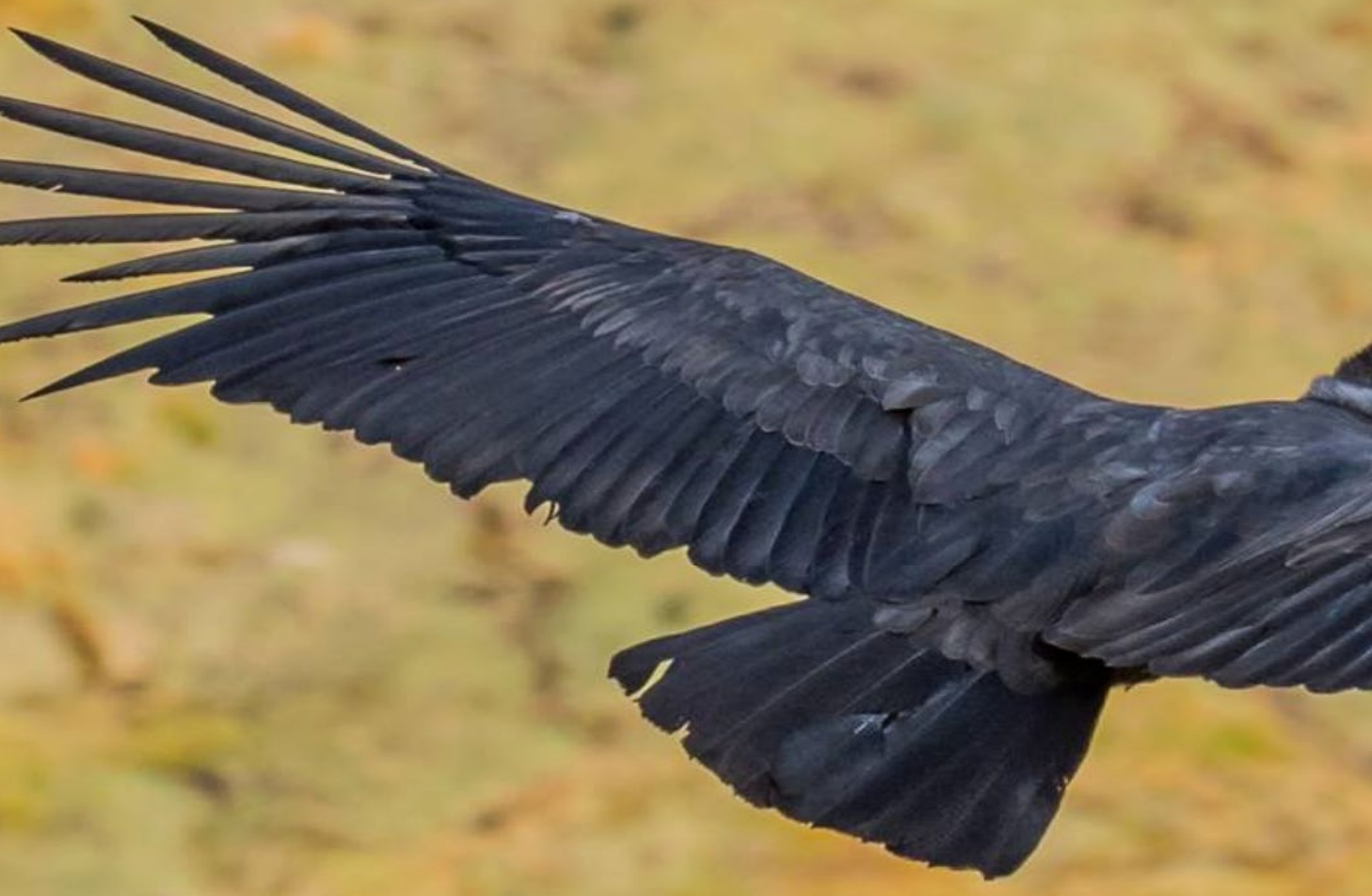

\section{ins:}

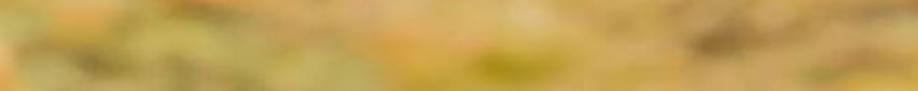

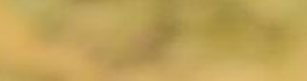

s.
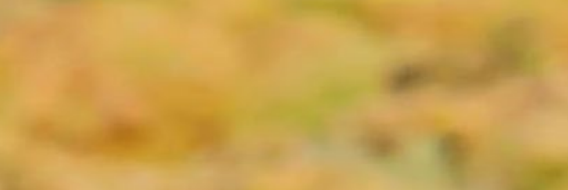

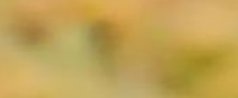

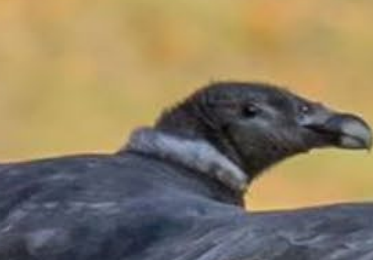


The concept of complementarity analyses refers to the degree of similarity in species composition between sites using an algorithm that iteratively selects maximum biological diversity in the minimum number of areas, with the objective of achieving representativeness of one or several populations of all species in the most efficient manner for conservation purposes (Pressey et al. 1997; Gil \& Moreno 2007). For the complementarity analysis of each vertebrate group we used a grid cell size of $2^{\circ} \times 2^{\circ}(\sim 200 \times 200 \mathrm{~km})$, which for the Amazon basin amounts to 254 cells. In the complementarity analysis, similarly to the beta-diversity analyses, methodologically we considered eliminating cells that were partially outside the limits of the basin. However, this step left only 89 cells and so we elected to retain all 254 cells and consider those on the periphery as cells subject to border effects.

Using the Quantum GIS tool Spatial Attributes Union, we calculated whether each species was present or not in each $2^{\circ} \times 2^{\circ}$ cell. Subsequently, we calculated a matrix of cells versus species, allowing us to calculate total species in each cell. Using the total values for each cell, we selected the cell with the highest species richness and then eliminated the species present in that cell from the matrix, selecting in turn the cell with highest diversity. This process was repeated until all species in basin were included in the selection. 


\section{Identification and taxonomic update of terrestrial}

vertebrate species in the Amazon basin and creation

of distribution polygons for additional amphibians,

reptiles and mammals

Following consultation with the major data sources detailed above and considering additional amphibian, reptile and mammal species for which we generated new digitalized distribution polygons, we determined the total number of amphibian, reptile, bird and mammal species in South America as detailed in Table 5.

Alpha, beta and gamma diversity analyses for the Amazon basin

\section{i. Alpha-diversity species analysis for the Amazon basin}

Due to time constraints and the sheer number of $1 \mathrm{~km}^{2}$ cells in South America, we conducted alpha-diversity species analysis at the scale of the Amazon basin, which do not differ significantly from maps included in previous reports although these analyses include new information for species of amphibians, reptiles and mammals without previous distribution data (for comparison purposes, here we present both versions of each map).

\section{A. Amphibians}

Amphibian species richness for South America (Figures 2 \& 3) highlights species concentrations per $\mathrm{km}^{2}$ in the Amazon basin, especially the western Amazon where concentrations reach up to 138 species per $\mathrm{km}^{2}$ (Figure 3). Due to their smaller range distributions, amphibians are the vertebrate group with the lowest level of representativeness within Protected Areas and Indigenous territories, and the twelve conservation mosaics supported by the Gordon and Betty Moore Foundation.

Our analysis highlights that the conservation mosaics are placed within the highest species concentrations of amphibian diversity per $\mathrm{km}^{2}$ in South America, for example, Yasuni-Pastaza, Ampiyacu, Yavari-Samiria, and part of Upper Purus, Itenez-Rondonia and Madeira.

Table 5. Number of Vertebrate Species in South America (with new geospatial information)

\begin{tabular}{|c|c|c|c|}
\hline Vertebrate Group & Source & $\begin{array}{c}\text { New Digitalized } \\
\text { Polygons }\end{array}$ & $\begin{array}{c}\text { Total Number of Species with } \\
\text { Geospatial Information }\end{array}$ \\
\hline Amphibians & Amphibian Species of the World & 388 & 2,807 \\
\hline Reptiles & Roll et al. (2017) \& IUCN & 154 & 2,138 \\
\hline Birds & IUCN-BirdLife & - & 3,607 \\
\hline Mammals & IUCN \& other sources & 270 & $1,329^{\star}$ \\
\hline
\end{tabular}




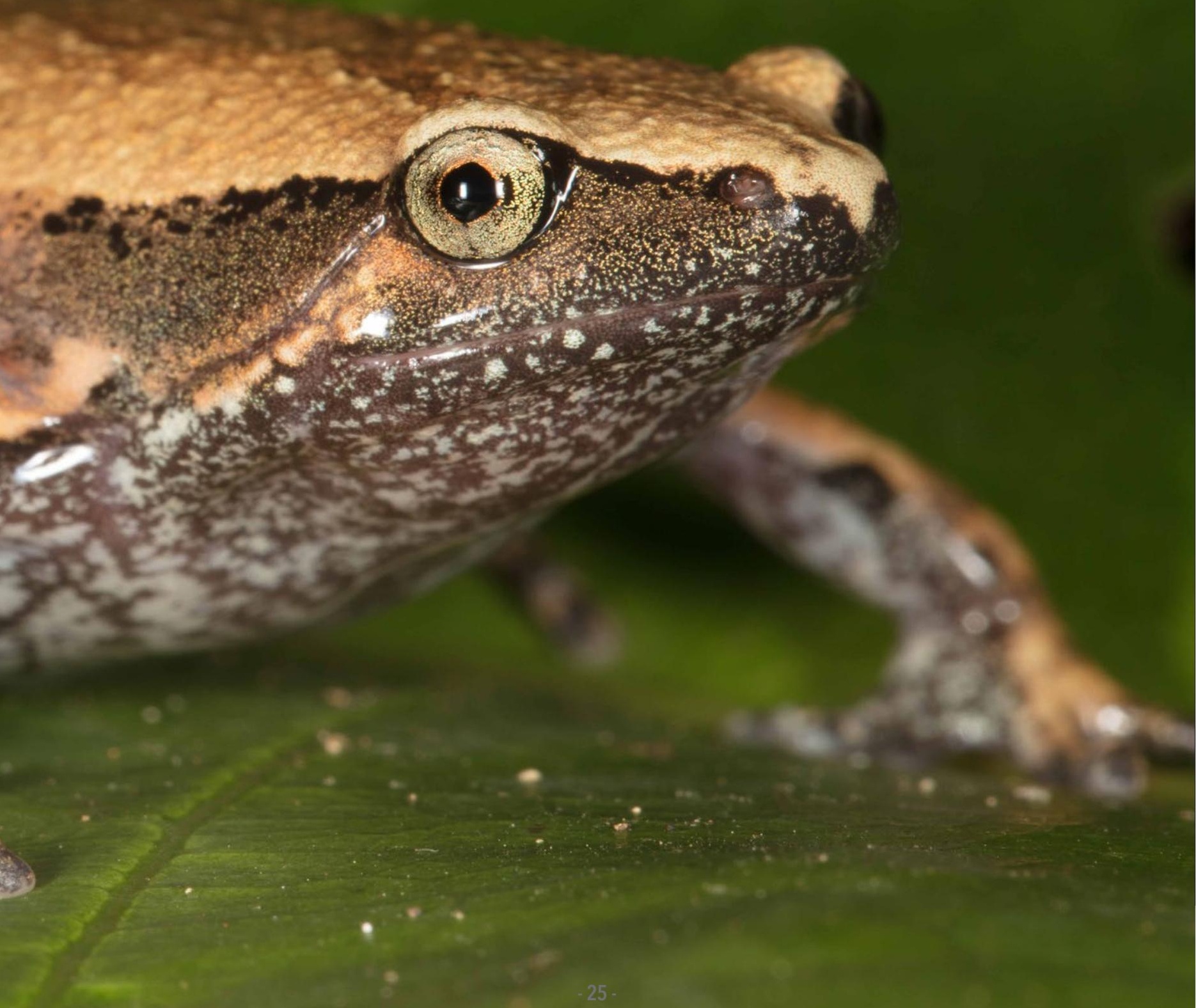


Several studies reported the western Amazon as an area with especially high amphibian species concentrations in South America (Duellman 1999; Finer et al. 2008; Jenkins et al. 2013; Roll et al. 2017). The origin of amphibian species diversification across the Amazon, and species diversification in general, has been the subject of several hypotheses (Hoorn \& Wesselingh, 2010; Hoorn et al. 2010; Defler 2019). The Andes uplift was the crucial event leading to the evolution of Amazonian ecosystems and landscapes, and inevitably much of amphibian diversity. The Andes have nutrient-rich soils linked to high diversities of amphibians and mammals in the western Amazon, as new lineages formed along the length of the Andes each of which moving into the Amazon and contributing to lowland diversity (Antonelli et al. 2010; Hoorn et al. 2010), for example, the wide expansion of the dendrobatids (Santos et al. 2009; Antonelli et al. 2010). Nevertheless, vertebrate alpha-diversity has been influenced by a number of factors in the Amazon, and apparently these vary in importance for each family in each vertebrate group (Antonelli et al. 2010).

Another important factor for amphibian diversity, and perhaps diversification in the western Amazon, is the relatively stable climate in terms of humidity and seasonality as compared to the eastern Amazon (Hoorn et al. 2010). These factors, in combination with the small home ranges typical of amphibians may explain the restricted amphibian distributions in the western Amazon (Antonelli et al 2010; Hoorn et al. 2010).
Vertebrate diversity is also evidenced by the large number of endemic species in the Amazon (Da Silva et al. 2005), principally Ecuador (150 species), northern Peru and Colombia (Olson et al. 1998; Duellman, 1999; Bass et al. 2010; González et al. 2018). Da Silva et al. (2005) defined eight areas of endemism importance for biodiversity in general, separated by the major rivers of the Amazon basin, again highlighting the western Amazon as especially important.

The areas with the highest concentration of threatened amphibians according to the IUCN also highlight the importance of the conservation mosaics supported by the Gordon and Betty Moore Foundation (Figure 4). Yasuni-Pastaza and Upper Purus protect areas with between 1 and 4 Critically Endangered (CR) species per km². Yavari-Samiria, Ampiyacu and part of Yasuni-Pastaza, Madidi-Tambopata and Upper Purus include areas with concentrations of Endangered (EN) species. Other conservation mosaics have concentrations of Vulnerable (VU) species, between 1 and 8 species per km² in Ampiyacu, Yavari-Samiria, YasuniPastaza, Madidi-Tambopata and a small portion of Upper Purus, Lower Rio Negro, Calha Norte, Chiribiquete-Caqueta, Upper Rio Negro and Xingu. Given the overall importance of the Amazon for amphibian diversity, this analysis underlines the importance of the conservation mosaics supported by the Gordon and Betty Moore Foundation for amphibian conservation, including threatened species, especially considering that amphibians are globally particularly threatened (Young et al. 2004). 


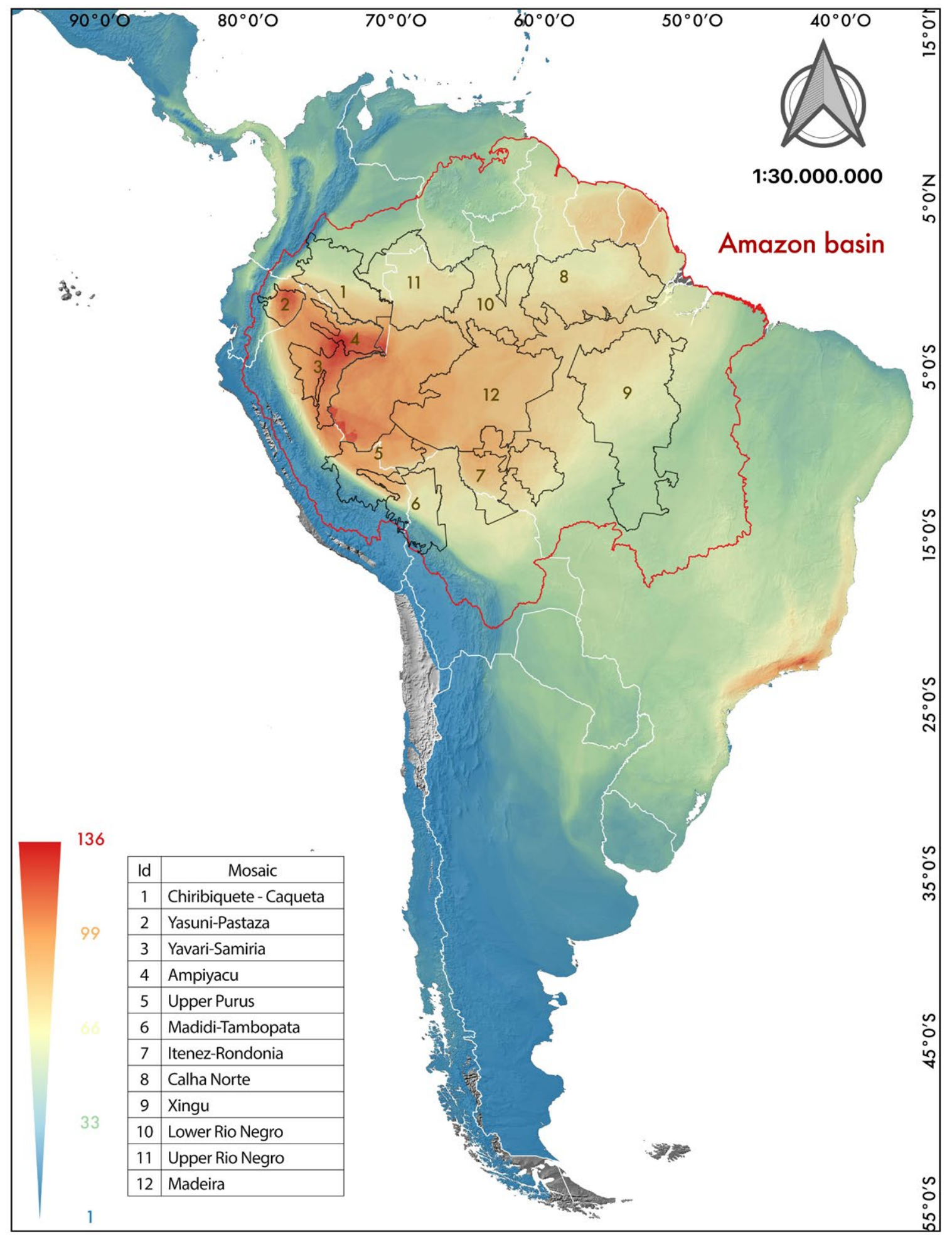

Figure 2: Amphibian Species Richness per km² in South America 


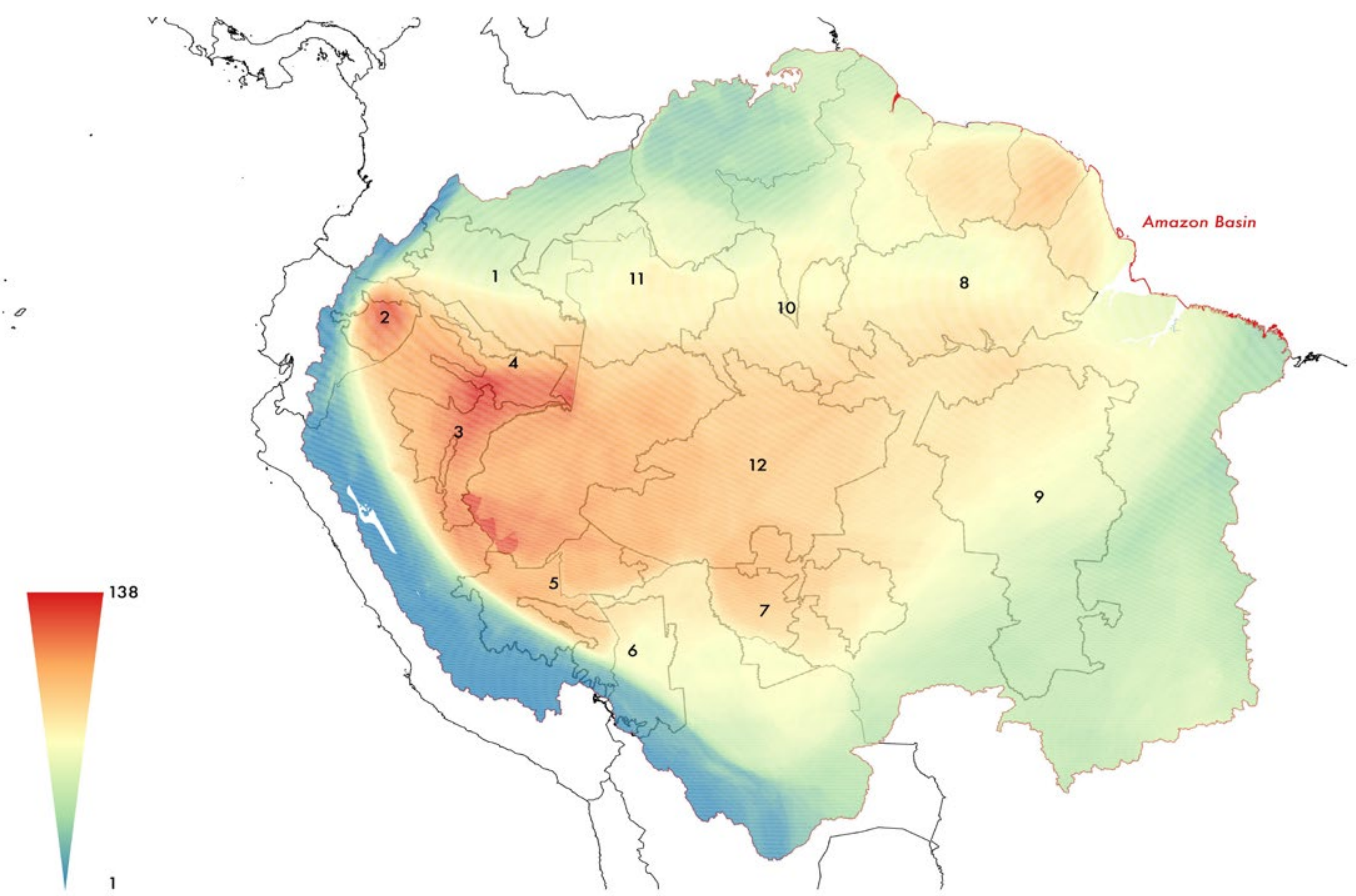

Figure 3: Amphibian Species Richness per km² in Amazon Basin

Figure 4: Threatened Amphibian Species Richness per $\mathrm{km}^{2}$ in Amazon basin using IUCN (2018) Red Lists. Threatened Categories: Critically Endangered (CR); Endangered (EN); Vulnerable (VU); Near Threatened (NT); Least Concern (LC); Data Deficient (DD); Not Evaluated (NE)

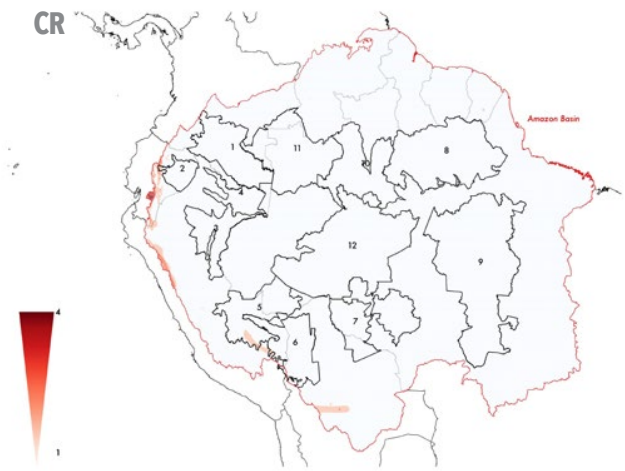

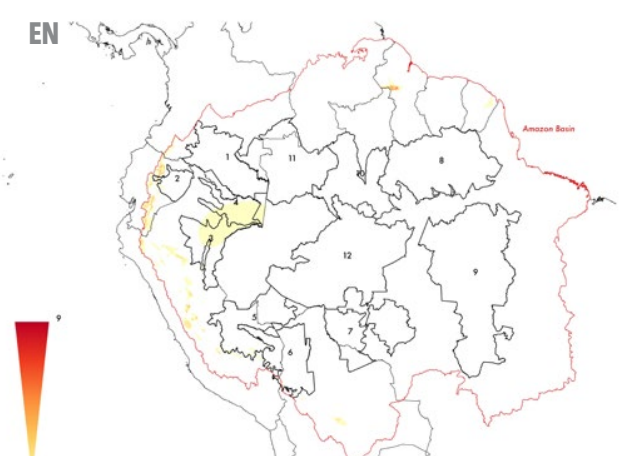

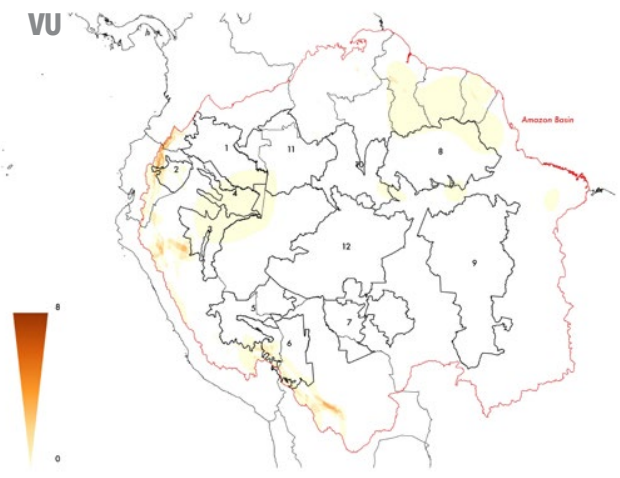




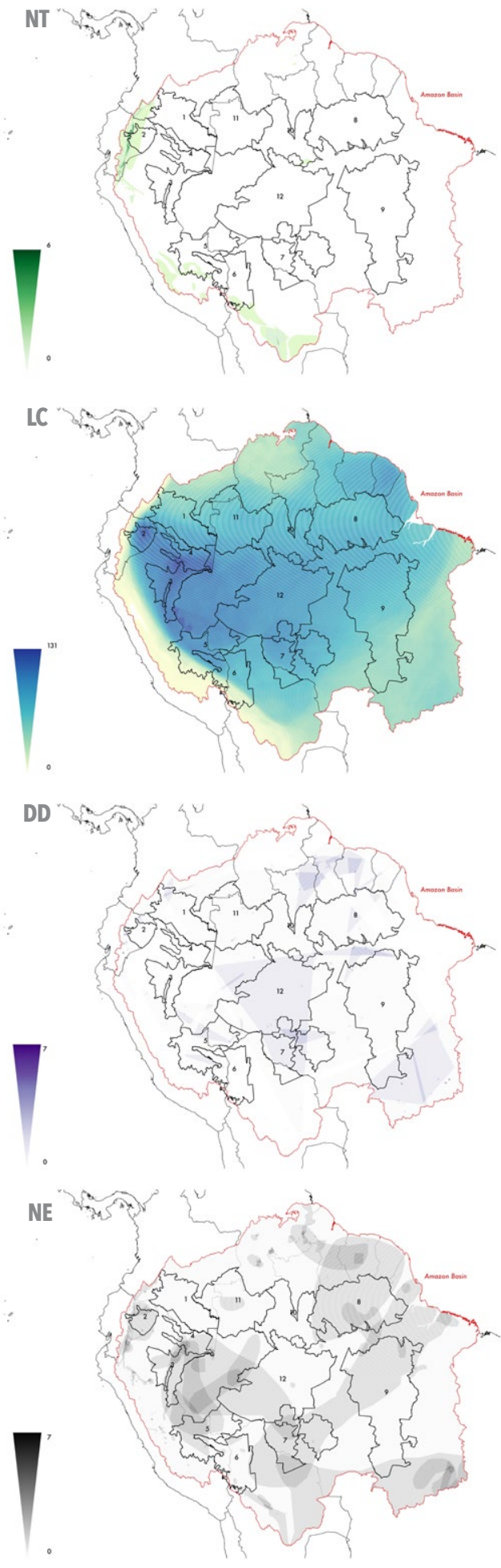

4 Figure 4 (cont.): Threatened Amphibian Species Richness per $\mathrm{km}^{2}$ in Amazon basin using IUCN (2018) Red Lists. Threatened Categories: Critically Endangered (CR); Endangered (EN); Vulnerable (VU); Near Threatened (NT); Least Concern (LC); Data Deficient (DD); Not Evaluated (NE)

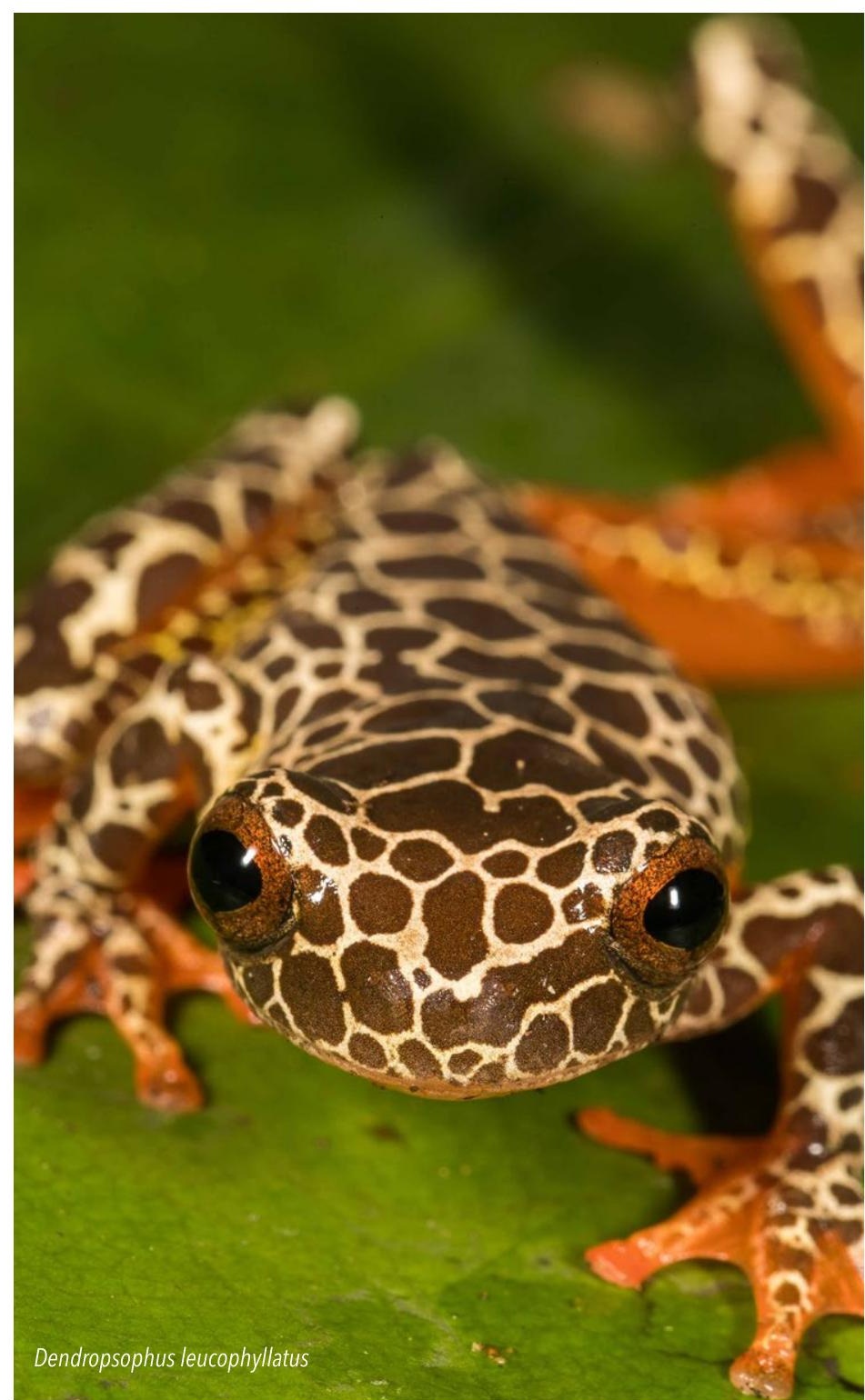




\section{B. Reptiles}

Most of the Amazon basin has a high concentration of reptile species (Figure 5). The highest concentrations of up to 184 species per $\mathrm{km}^{2}$ are in northwestern Amazonia and northern central Amazonian Brazil. Again these areas highlight the importance of the twelve conservation mosaics supported by the Gordon and Betty Moore Foundation, including Calha Norte, Xingu, ItenezRondonia, Madeira, Yavari-Samiria, Ampiyacu, Upper Río Negro and Lower Río Negro, as concentrations for reptile diversity. We were unable to perform these analyses for reptiles in South America, however the polygons were derived from a global analysis that highlighted the highest concentration of South American reptile diversity in the Amazon (Roll et al. 2017).

The origin of reptile diversification in the Amazon is contentious, especially due to the poorly studied situation of the group, with relatively few records across the region (Antonelli et al. 2010), which also limits our own analyses and highlights the particular need for targeted ecological and phylogeographic research. Studies have revealed a genetic divergence in the Late Miocene and Plio-Pleistocene (Antonelli et al. 2010), when different reptiles lineages appeared, reflecting an ecological partition in the Amazon environments probably linked to numerous large rivers and resulting separation (Antonelli et al. 2010; Riff et al. 2010). Again, there is significant reptilian endemism in the Amazon, for example in Ecuador there are 121 endemic species, and in Amazonian Brazil 81 species of lizards (Trefaut 2005; Bass et al. 2010).

The areas with the highest concentration of IUCN recognized threatened reptile species highlight the importance of the twelve conservation mosaics supported by the Gordon and Betty Moore Foundation (Figure 6). Yasuni-Pastaza includes areas with between 1 and 4 Endangered (EN) reptiles per $\mathrm{km}^{2}$, and areas with between 1 and 5 Vulnerable (VU) species per $\mathrm{km}^{2}$ are found in all twelve mosaics, principally Calha Norte, part of Xingu, Madeira, Yavari-Samiria, Yasuni-Pastaza, Ampiyacu, Upper Río Negro and Lower Río Negro (with 4 to 5 VU species per km²). Critically Endangered (CR) reptiles are found in concentrations of just 1 species per $\mathrm{km}^{2}$ in part of the Upper Purus and Chiribiquete-Caqueta, as well as close to the northern limits of the Upper Río Negro and Lower Río Negro. Near Threatened (NT) reptiles are found in the Upper Río Negro, Lower Río Negro, and parts pf Madeira, Calha Norte, Madidi-Tambopata, Upper Purus, Yavari-Samiria, Ampiyacu and Chiribiquete-Caqueta (Figure 6), whilst Least Concern (LC) reptiles reach concentrations of up 51 species per $\mathrm{km}^{2}$ across the twelve mosaics. Together this data clearly demonstrates the contribution of the conservation mosaics towards the conservation of reptile diversity, as well as for the threatened reptiles of the Amazon. 


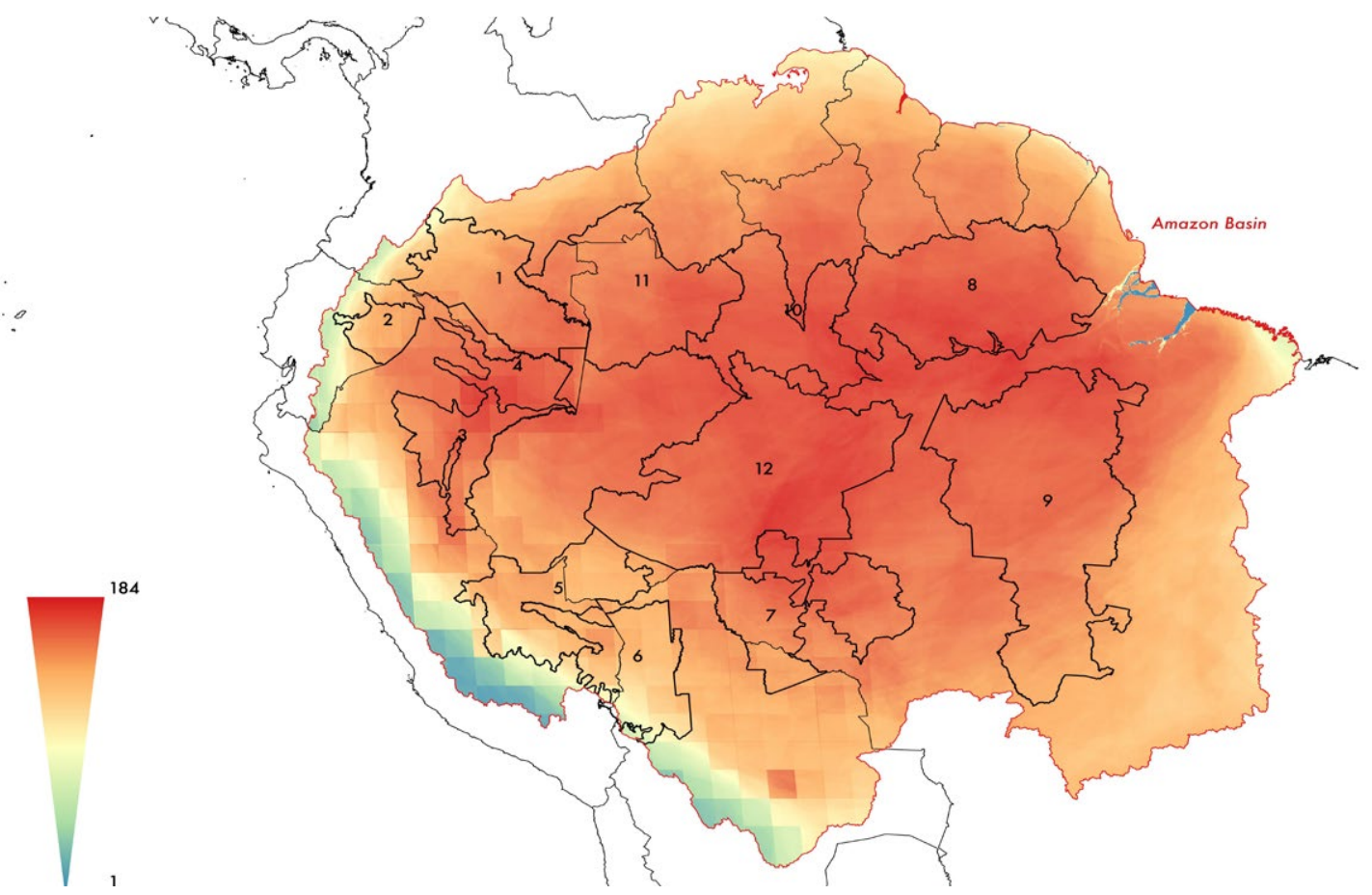

Figure 5: Reptile Species Richness per km² in Amazon Basin
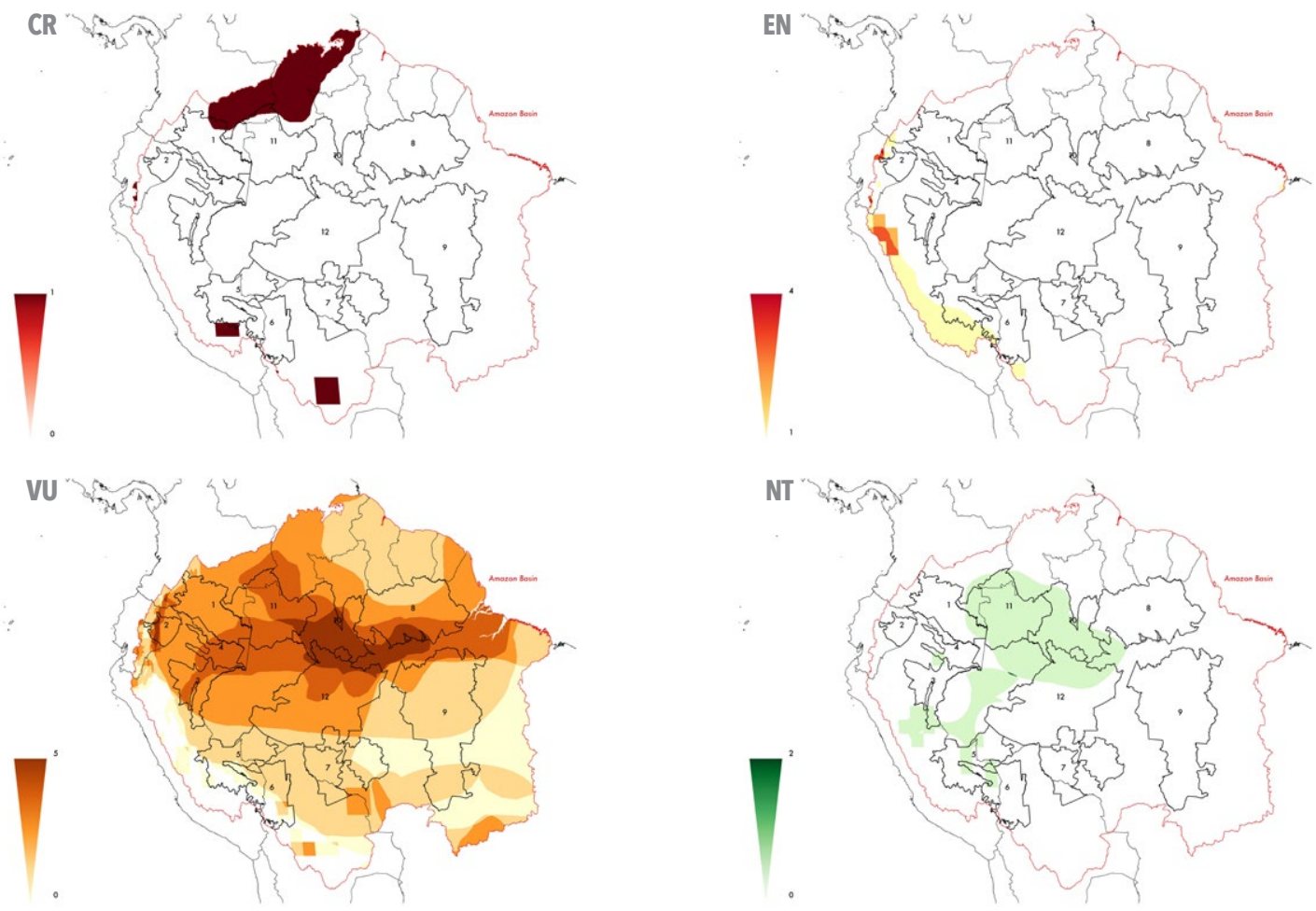

Figure 6: Threatened Reptile Species Richness per km² in Amazon basin using IUCN (2018) Red Lists. Threatened Categories: Critically Endangered (CR); Endangered (EN); Vulnerable (VU); Near Threatened (NT) ;Least Concern (LC); Data Deficient(DD); Not Evaluated (NE); Lower Risk/Conservation Dependent(LR/CD); Lower Risk/Least Concern (LR/LC). 

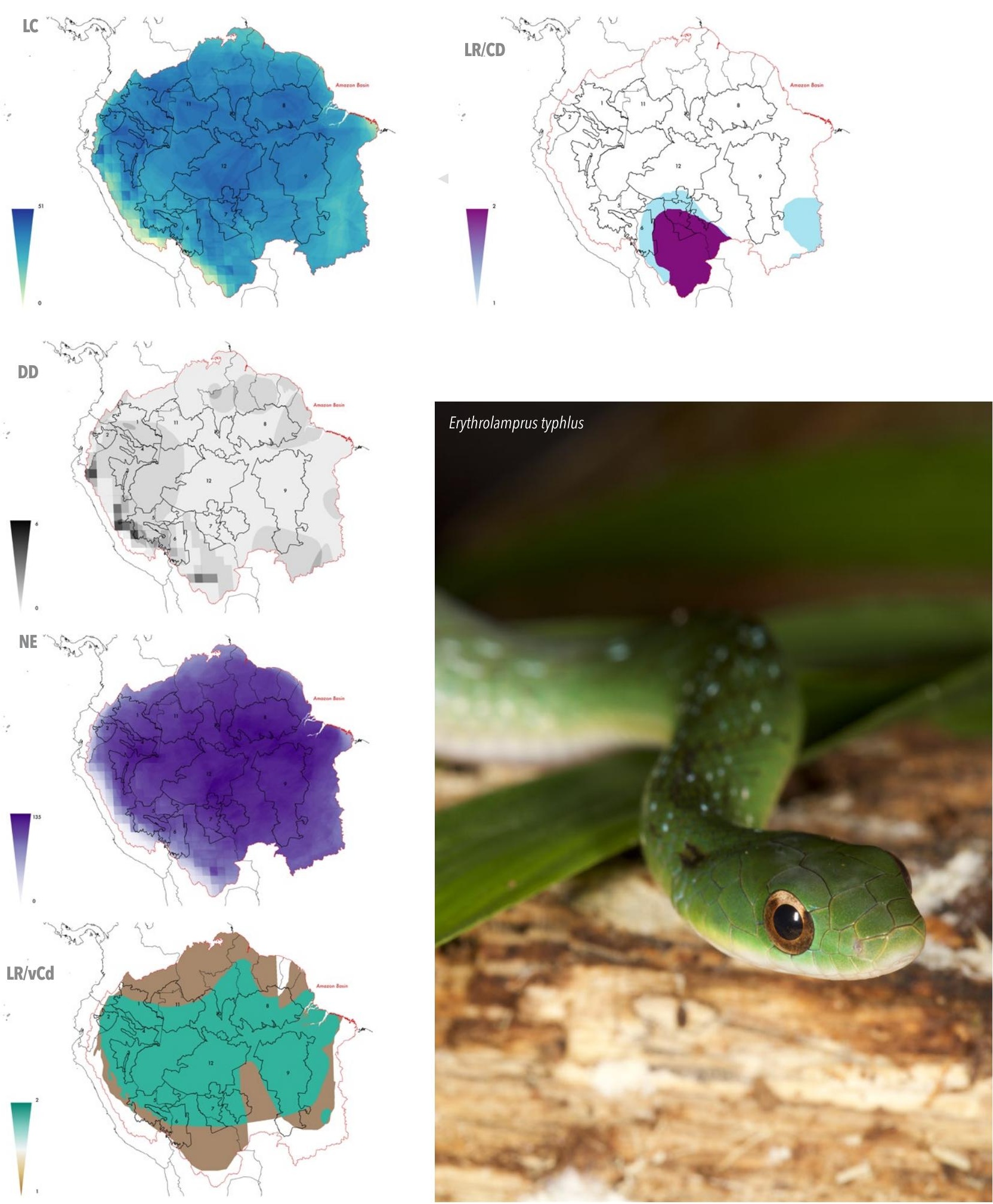

Figure 6 (cont.): Threatened Reptile Species Richness per $\mathrm{km}^{2}$ in Amazon basin using IUCN (2018) Red Lists. Threatened Categories: Critically Endangered (CR); Endangered (EN); Vulnerable (VU); Near Threatened (NT); Least Concern (LC); Data Deficient (DD); Not Evaluated (NE); Lower Risk/Consenvation Dependent (LR/CD); Lower Risk/Least Concern (LR/LC). 


\section{Birds}

The majority of the areas with the highest concentration of bird species in South America are found in the Amazon basin (Figures $7 \& 8$ ). Once again, the areas with the highest concentrations of up to 596 species per $\mathrm{km}^{2}$ are Amazonian, especially in the western Amazon, highlighting the importance of the Yasuni-Pastaza, Yavari-Samiria, Ampiyacu, Upper Purus conservation mosaics, and parts of the MadidiTambopata, Madeira, Calha Norte and Xingu conservation mosaics.

The Andean event is the predominant theory explaining bird diversification in the western Amazon (Antonelli et al. 2010). A study on patterns of bird species richness in South America showed greater diversity in the Andes towards Amazonian Ecuador, southeastern Peru and southern Bolivia in complex physiographical landscapes, a pattern that also responds to climatic fluctuations (Rahbek \& Graves 2001). Another study suggested that Andean lineages of a group of Passeriformes dispersed to other geographic areas of the Neotropics, eventually leading to speciation events (Burns \& Naoki 2004). Bates (2001) proposed that the concentrations in Guyana respond to marine influences that led to high endemism in northern South America. Similarly, coastal northern Brazil has many records of migratory birds from the northern hemisphere, increasing species richness (AzevedoJúnior 1998).

The areas with the highest concentration of threatened bird species according to the lower threatened IUCN categories (NT, LC) in South America are predominantly found in the Amazon (Figure 7), whereas Endangered and Vulnerable concentrations are predominantly concentrated outside the Amazon. In South America concentrations of Critically Endangered species reach 4 species per $\mathrm{km}^{2}$ and are found in eastern Brazil and small portions of Bolivia, Ecuador, Argentina, Peru and Chile, and within the Madidi-Tambopata conservation mosaic. 


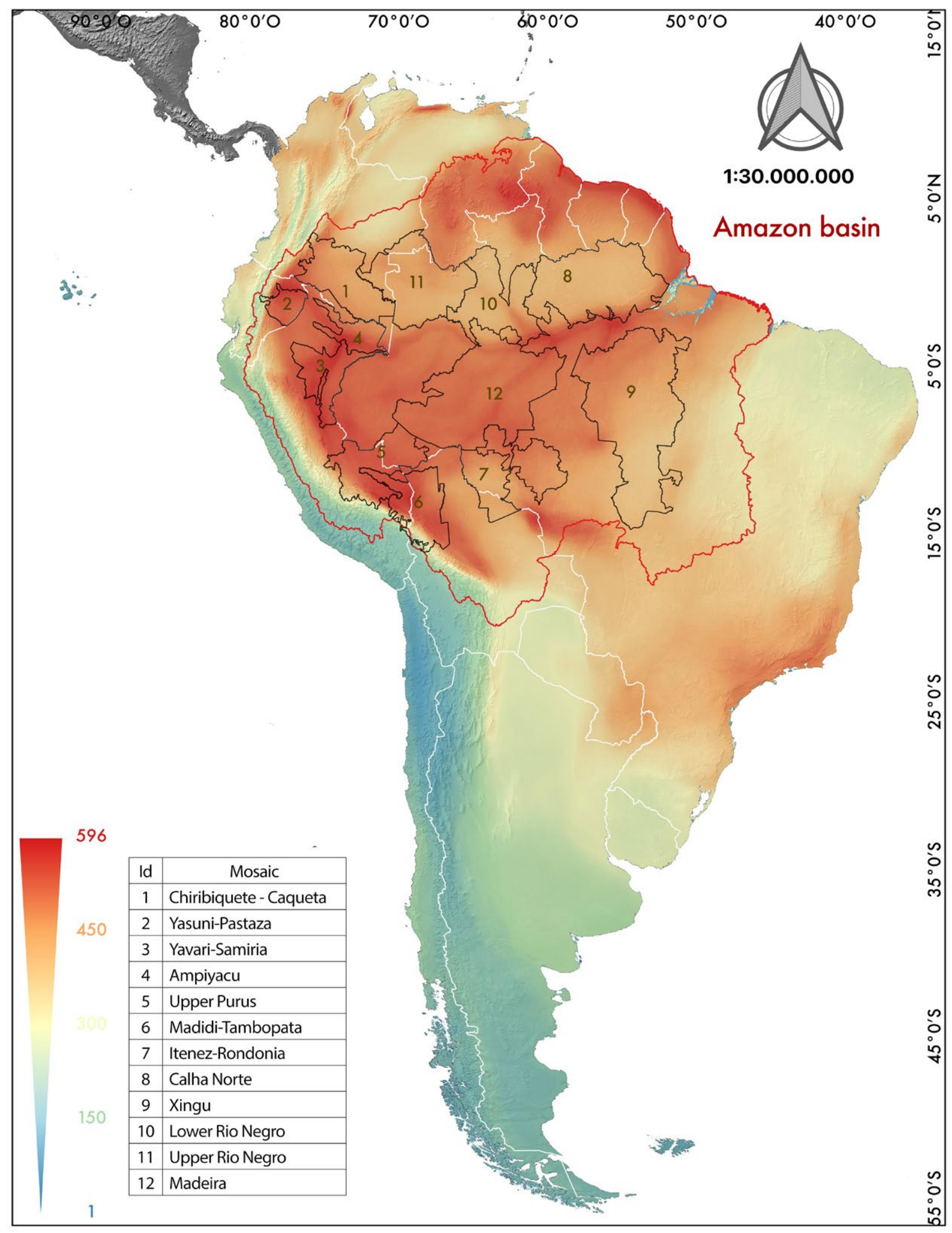

Figure 7: Bird Species Richness per $\mathrm{km}^{2}$ in South America and Amazon basin 


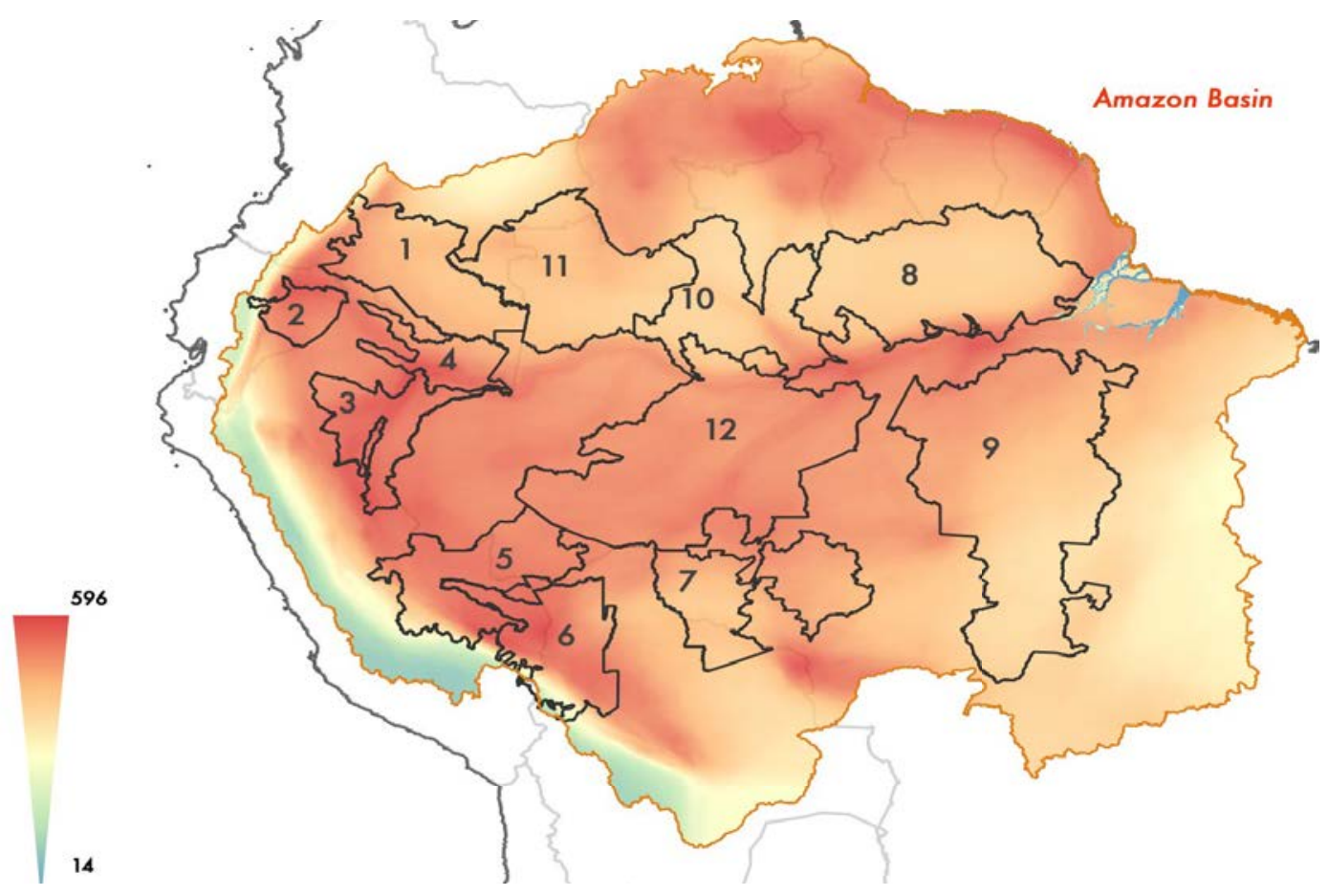

Figure 8: Bird Species Richness per km² in Amazon Basin
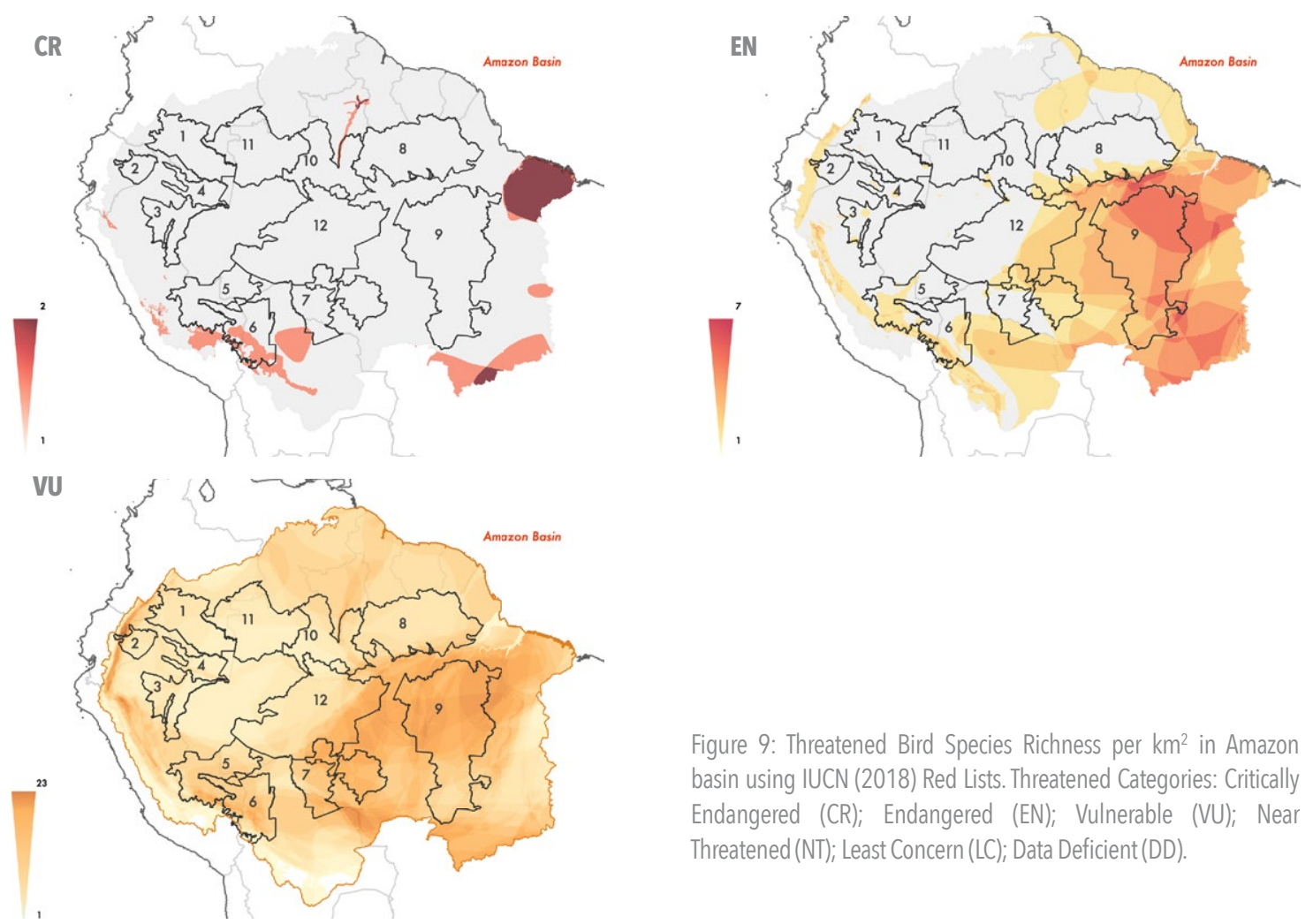

Figure 9: Threatened Bird Species Richness per $\mathrm{km}^{2}$ in Amazon basin using IUCN (2018) Red Lists. Threatened Categories: Critically Endangered (CR); Endangered (EN); Vulnerable (VU); Near Threatened (NT); LeastConcern (LC); Data Deficient(DD). 

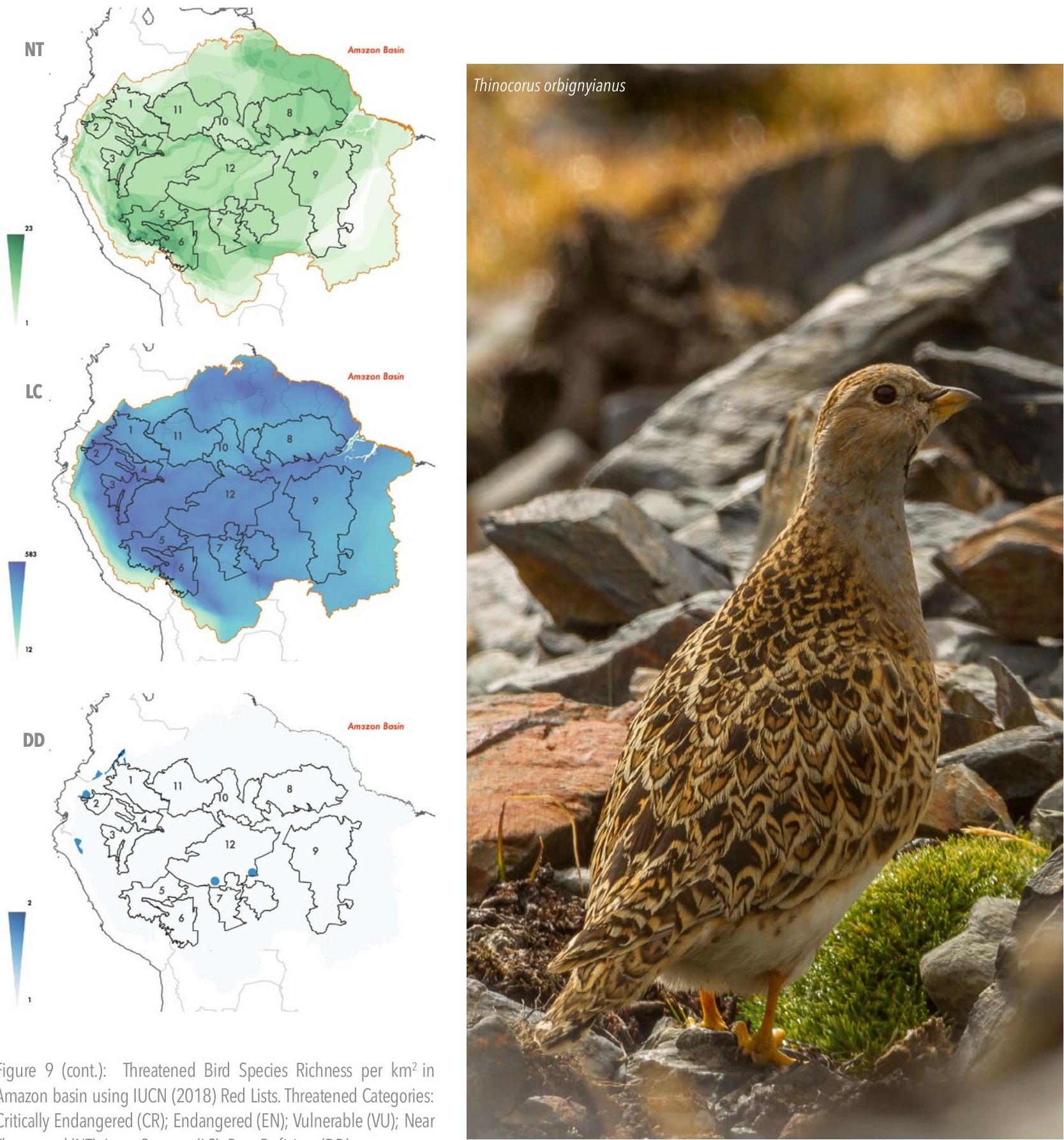

Figure 9 (cont.): Threatened Bird Species Richness per $\mathrm{km}^{2}$ in Amazon basin using IUCN (2018) Red Lists. Threatened Categories: Critically Endangered (CR); Endangered (EN); Vulnerable (VU); Near Threatened (NT); Least Concern (LC); Data Deficient(DD). 


\section{Mammals}

The majority of the areas with the greatest concentration of mammal species in South America are found in the Amazon basin (Figures $10 \& 11)$. Again, the areas with the highest concentrations of up to 203 species per $\mathrm{km}^{2}$ are Amazonian, especially in the western Amazon, highlighting the importance of the Yasuni-Pastaza, Yavari-Samiria, Ampiyacu, Upper Purus and Madidi-Tambopata conservation mosaics.

The high alpha-diversity of mammals in the western Amazon is also attributed to the rise of the Andes (Defler 2019), although the debate continues (Hoorn et al. 2010; Defler 2019). Compared to the eastern Amazon, the soils of the western Amazon in the Neogene are characterized by high nutrient levels (Hoorn et al. 2010), and soil richness is related to increased productivity and diversity. Tognelli and Kelt (2004) suggested that mammal species richness in South America is influenced by productivity and that this is reflected in a gradual gradient, with higher concentrations on the lower slopes of the eastern Andes in Bolivia, Perú and Ecuador, then the Amazonian plains, and then the Atlantic forests of Brazil. Higher productivity signifies increased resources for consumers, influencing population dynamics, and increasing the number of species that can co-exist (MacArthur 1972; Lennon et al. 2000; Defler 2019).

Similarly, high mammal species richness in northern South America may be biogeographically influenced by the ancient and prominent Guinean Shield (Lim 2012), an elevated area that was relatively stable during the emergence of the Andes and Amazon in the Miocene, a period of significant environmental change, and influenced mammal diversification, principally bats, increasing endemism and functioning as a geographic barrier (Lim 2012; Lim \& Tavares 2012). Other authors maintain that the Amazon is characterized by high rainfall for most of the year, which is related to high mammal species richness (Voss \& Emmons 1996) and plant species richness (Gentry 1988; Pitman et al. 2002).

The areas with the highest concentrations of threatened mammals according to the IUCN (Figure 12) reveal that the Amazon is especially relevant for most threatened categories (LC, NT, VU, EN). Nevertheless, this is not the case for the Critically Endangered category (CR), with concentrations of up to 2 species per $\mathrm{km}^{2}$ in Colombia, Brazil and small portions of Bolivia, Ecuador and Peru. The Chiribiquete-Caqueta conservation mosaic has small areas with concentrations of the most threatened species, although Itenez-Rondonia, and parts of Madeira, Xingu and Calha Norte have concentrations of Endangered (EN) mammal species. Vulnerable (VU) species are concentrated in Yavari-Samiria and Calha Norte, as well as concentrations of species in the LC, NT and DD categories. 


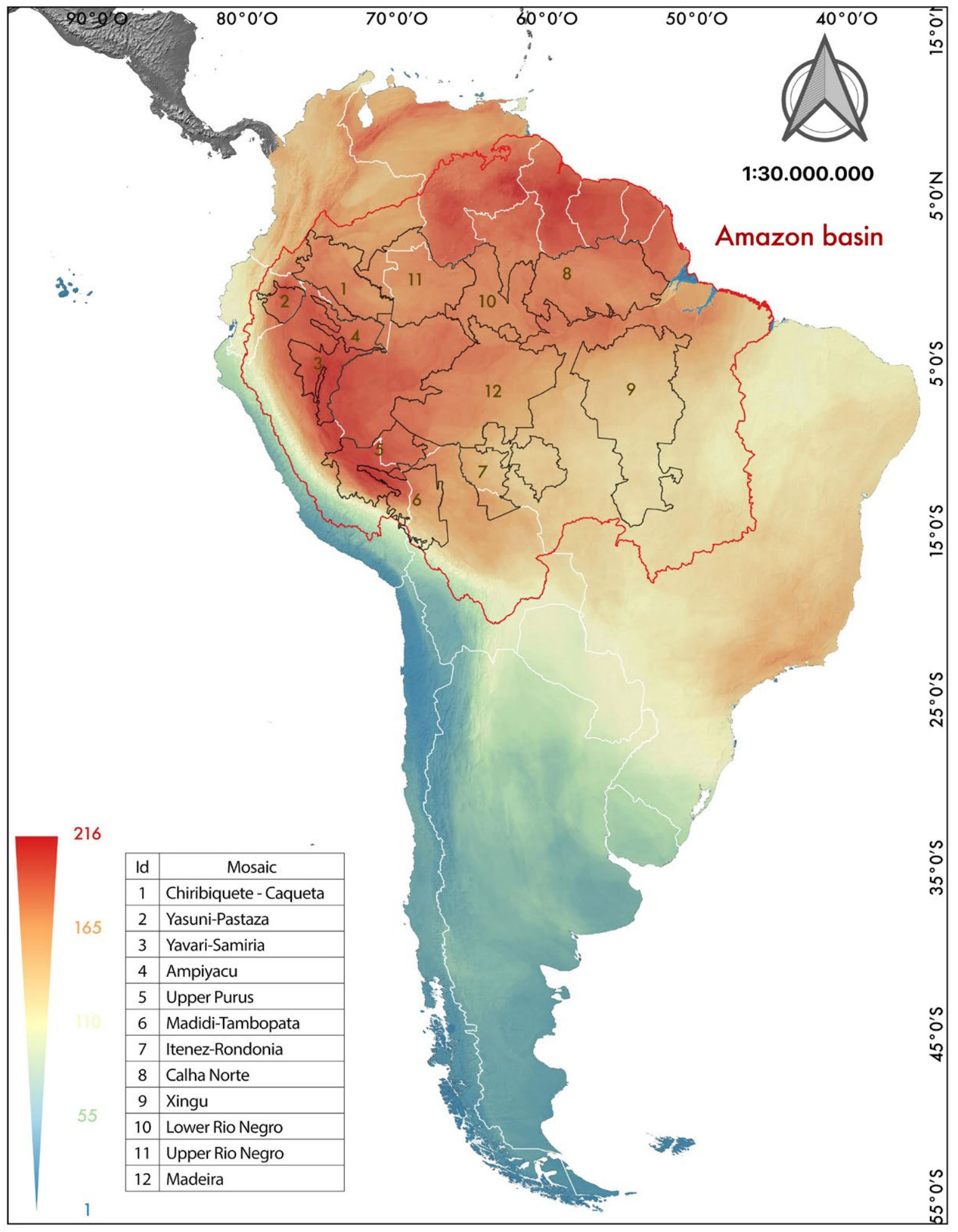

Figure 10: Mammal Species Richness per $\mathrm{km}^{2}$ in South America 


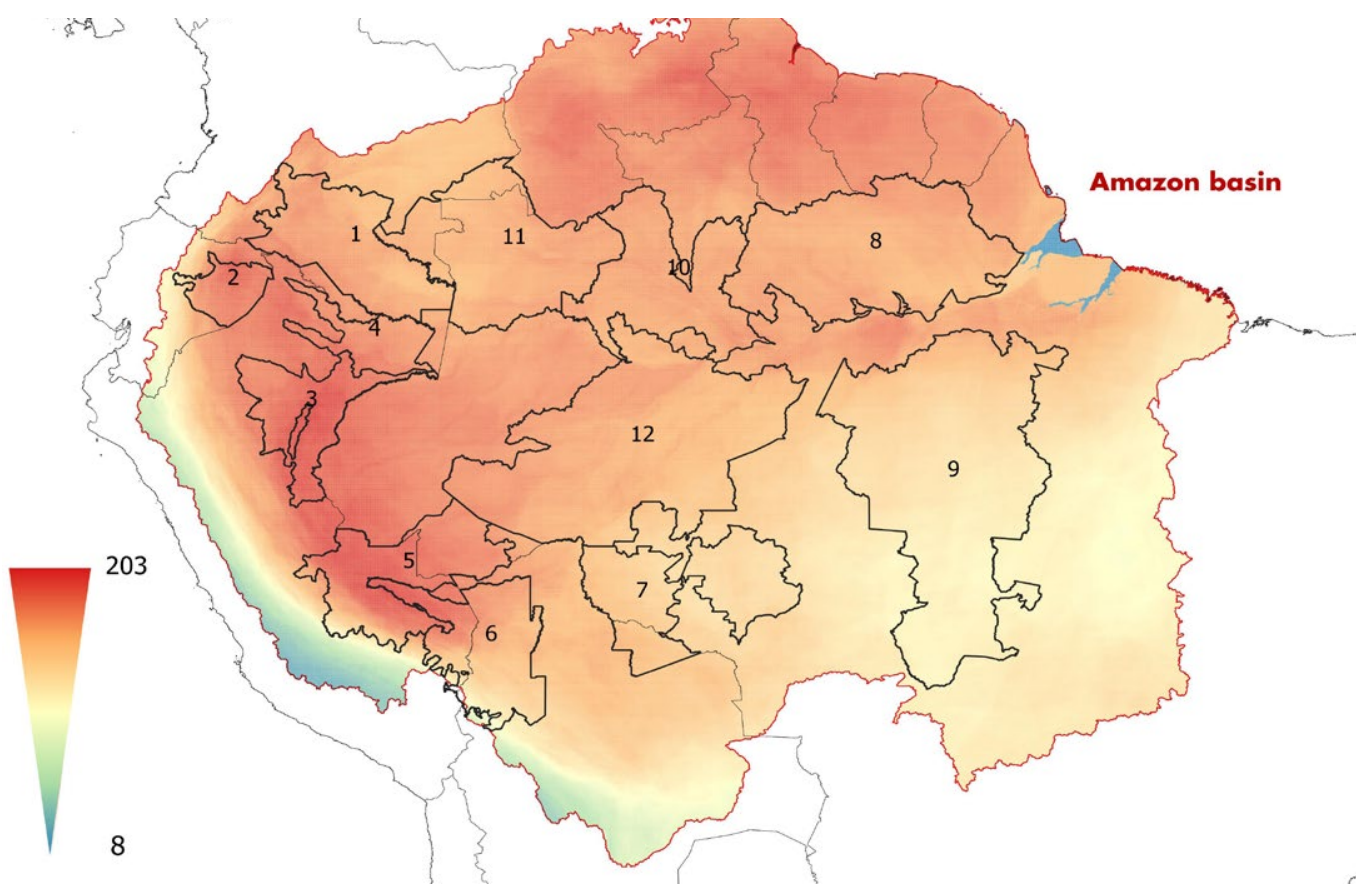

Figure 11: Mammal Species Richness per km² in Amazon Basin

Figure 12: Threatened Mammal Species Richness per $\mathrm{km}^{2}$ in Amazon basin using IUCN (2018 \& 2019) Red Lists. Threatened Categories: Critically Endangered (CR); Endangered (EN); Vulnerable (VU); Near Threatened (NT); Least Concern (LC); Data Deficient (DD); Not Evaluated (NE).

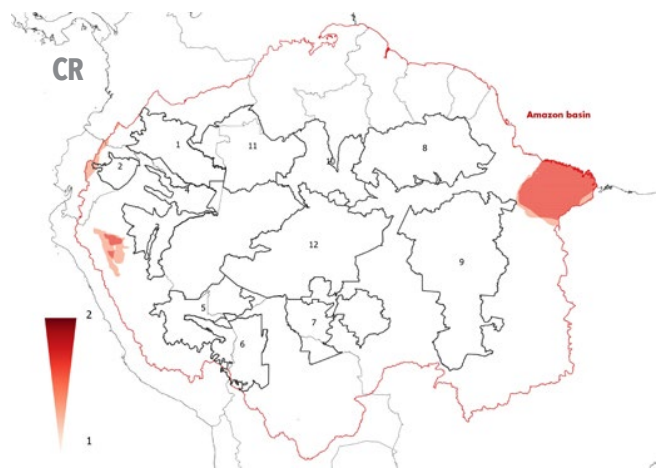

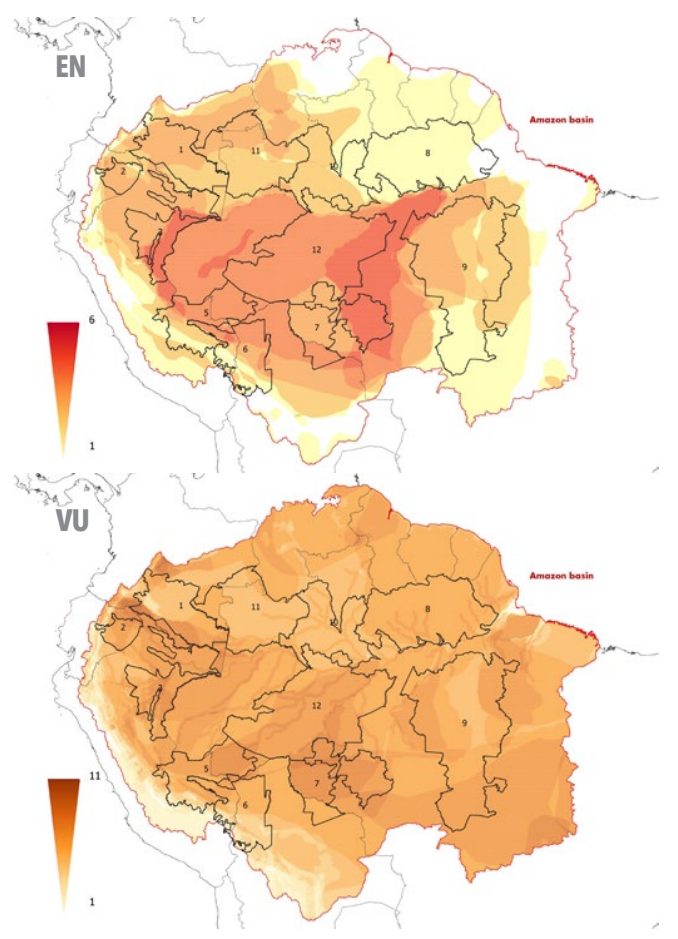




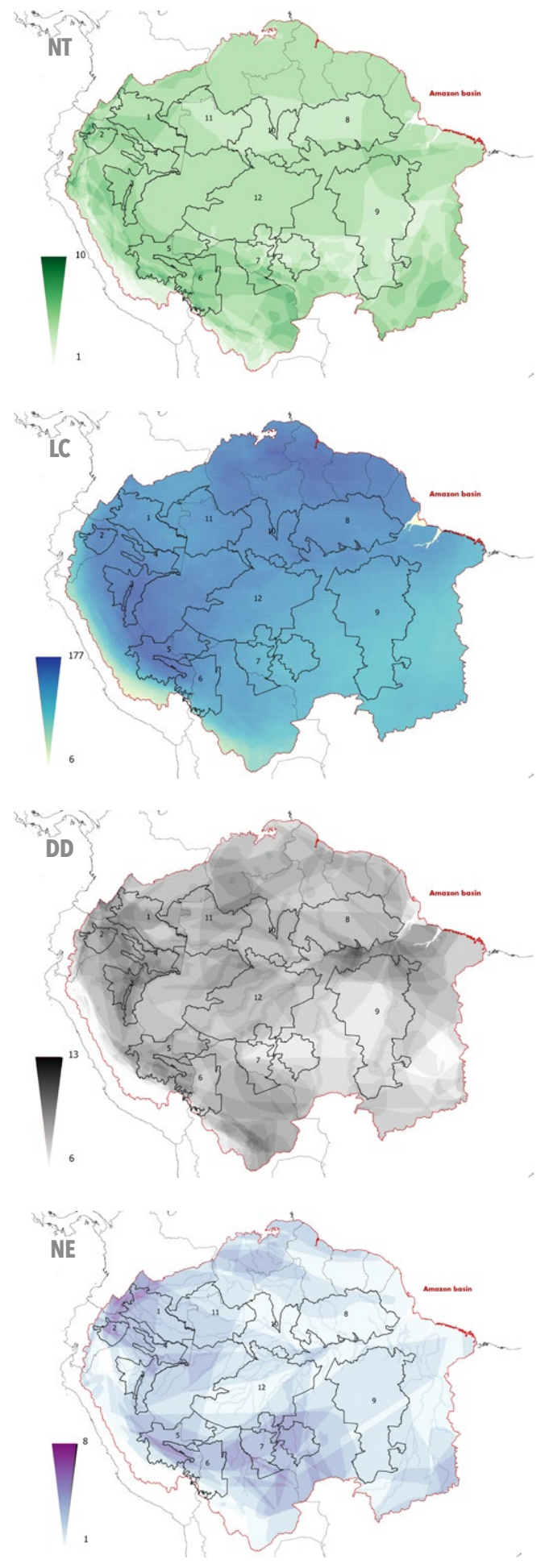

4 Figure 12 (Cont.): Threatened Mammal Species Richness per km² in Amazon basin using IUCN (2018 \& 2019) Red Lists. Threatened Categories: Critically Endangered (CR); Endangered (EN); Vulnerable (VU); Near Threatened (NT); Least Concern (LC); Data Deficient (DD); NotEvaluated(NE).

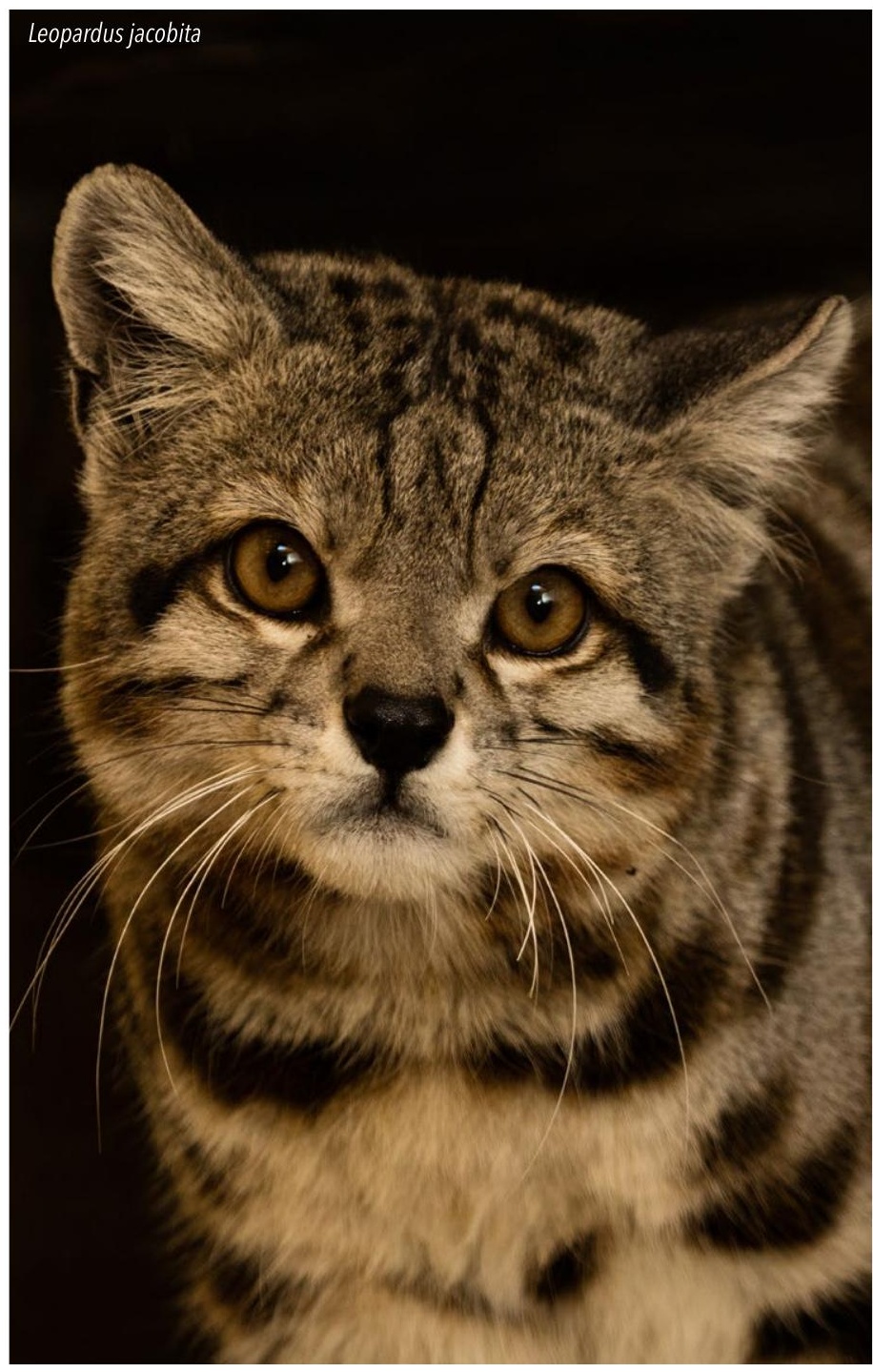


As mentioned previously, there are several theories to explain the origin of diversification for each of the four vertebrate groups (Antonelli et al. 2010), although it is widely accepted that Amazonian biodiversity is a result of more than one driving mechanism (Hoorn et al. 2010; Hoorn \& Wesselingh 2010). Nevertheless, the emergence of the Andes in the Neogene, fundamentally changed the hydrology and climate of the entire continent, creating new evolutionary pressures on montane and lowland taxa (Tognelli \& Kelt 2004; Antonelli et al. 2010). Historically, the extensive tropical forest of the Amazon has fragmented and undergone structural alterations, for example, marine incursions, geotectonic events, hydrology and wetland systems and climate fluctuations, which also created evolutionary pressures leading to extinctions or speciation (Antonelli et al. 2010; Hoorn et al. 2010; Lim 2012; Defler 2019). Collectively these mechanisms have led to the Amazon basin having the highest concentration of species in South America, and one of the highest in the world (Myers et al. 2000).

It is worth highlighting that the Amazon is also known for extremely high fish diversity. In the future it would be important to perform similar alpha-diversity analyses for fish to complete the first comprehensive assessment of vertebrate diversity for the Amazon.

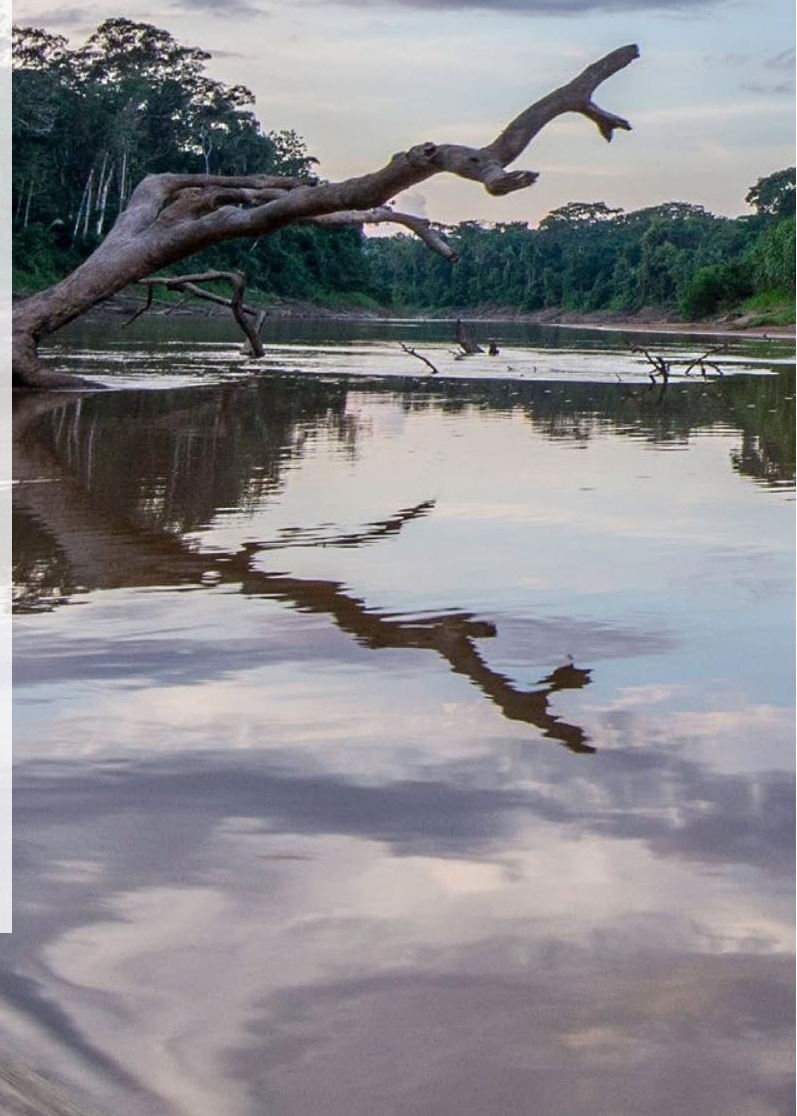




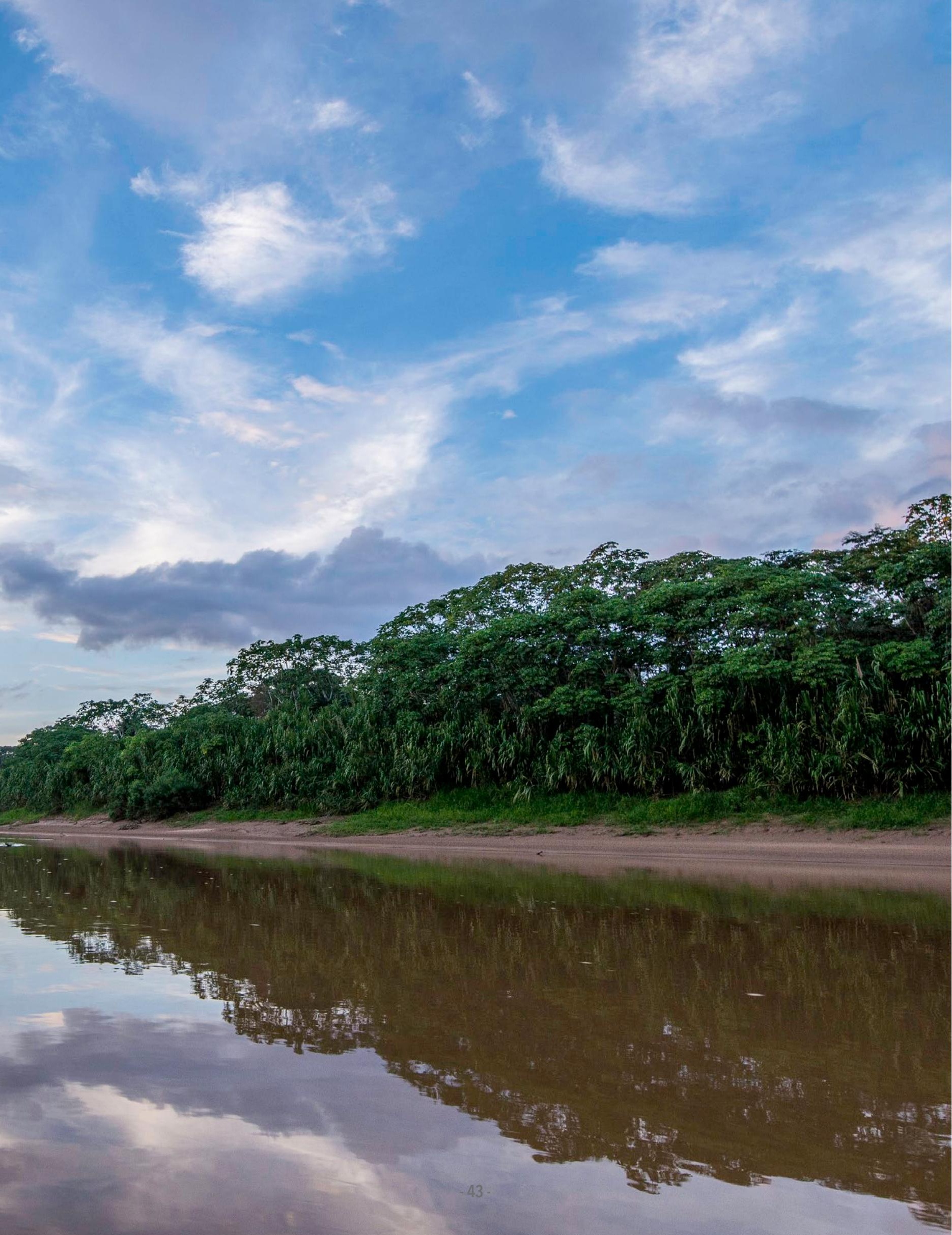




\section{ii. Beta diversity species analysis for the Amazon basin}

Our results demonstrate that the geographical patterns of betadiversity $(\beta)$ for amphibians, reptiles, birds and mammals have similar tendencies for all scales examined, with high values towards the Andes and intermediate values in the lowlands of the western Amazon (Figure 13), indicating a higher changeover of species in these areas. Previous studies at different scales also indicated higher beta-diversity towards the Andes (Duellman 1999; Melo et al. 2009; Oian 2009). Rodríguez et al. (2019) also determined the importance of montane areas in México for beta-diversity for vertebrates, identifying that altitudinal differences is the most significant indicator in species composition divergence. Indeed, geographical differentiation is recognized as the most compelling explanation for historical isolation processes that led to species composition differences in these regions (Melo et al. 2009).

Amphibians had the highest beta-diversity, particularly along the Andes chain from Colombia to southern Bolivia (Figure 13). Previous studies have demonstrated that amphibians and reptiles have higher beta-diversity values than birds and mammals (Buckley \& Jetz 2008; Qian 2009; Rodriguez et al. 2019), and species with lower dispersion capacities tend to have higher beta-diversity values (Qian 2009; Juen \& De Marco 2011).
Previous studies have shown that beta-diversity $(\beta)$ varies at different scales, indicating that species composition similarity increases with increase in the size of cell (MacNally et al. 2004; Lira-Noriega et al. 2007; Ochoa-Ochoa et al. 2014). In our study beta-diversity values for smaller scales differed to those at larger scales for reptiles, birds and mammals, following a similar pattern (Figure 13). Small cell analyses $(25 \times 25 \mathrm{~km} \& 50 \times 50 \mathrm{~km})$ for these vertebrate groups showed intermediate beta-diversity values in the Andes, higher values on the Amapá coast of Brazil, and lower values for the rest of the Amazon. At broader spatial scales (100 $x 100 \mathrm{~km} \& 200 \times 200 \mathrm{~km}$ ), all three vertebrate groups present high beta-diversity in the Andes, with intermediate values in the eastern and northern Amazon, particularly for birds (Figure 13).

Contrastingly, amphibians have high beta-diversity values in the smaller cells, principally in the Andes, and lower values towards the eastern Amazon (Figure 13). The Andes also had higher beta-diversity values for the broader scale analyses, as well as in Venezuela, Guyana and the southeastern Brazilian Amazon.

Heterogeneous environmental effects are expected to increase with increasing scale, because larger sampling units tend to include a greater variability in environmental conditions (Qian 2009; Rodriguez et al. 2019). High beta-diversity values indicate significant habitat heterogeneity. Where habitats differ across a geography or gradient (temperature, humidity, altitude, etc.), 

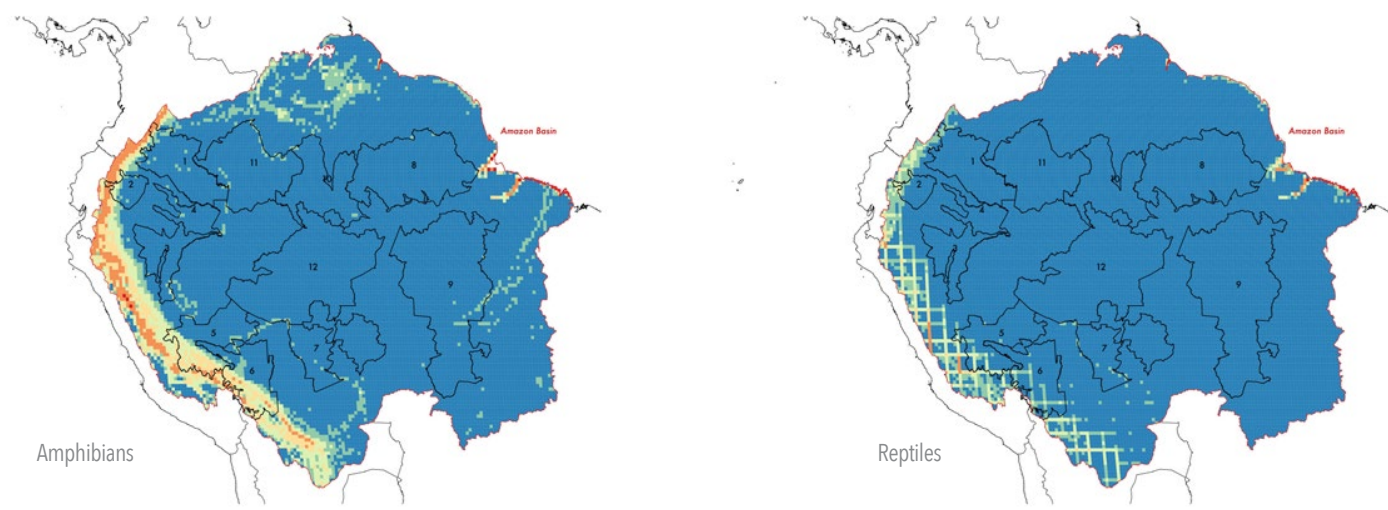

ำ
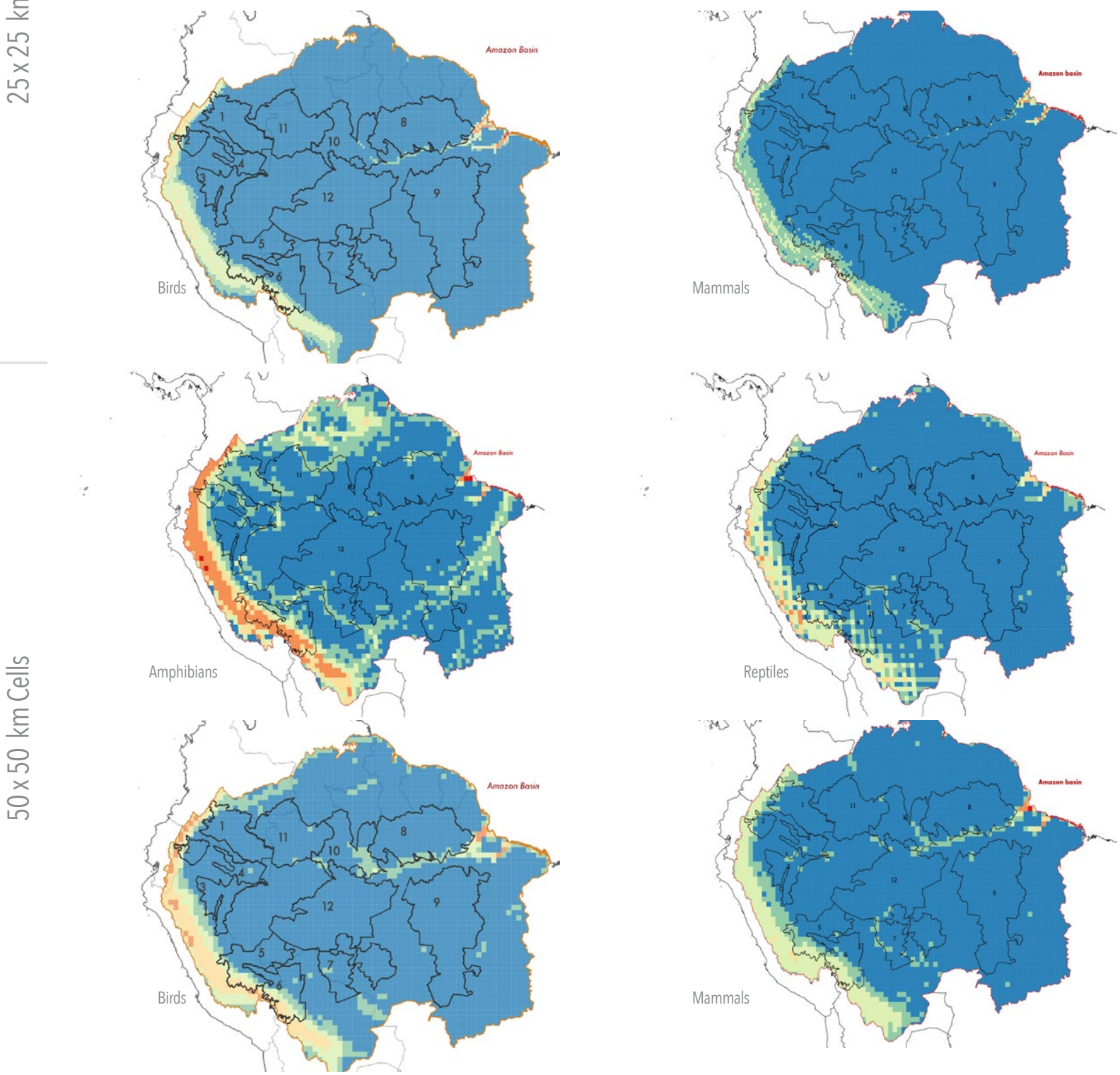

$1-1.1 \square 1.1-1.2$
0

$1.2-1.5$

$1.5-2$

$2-10$

$>10$

Figure 13. Geographic patterns of beta-diversity ( $\beta$ ) following Whittaker (1960) for amphibians, reptiles, birds and mammals at different spatial scales in the Amazon basin and twelve conservation mosaics supported by the Gordon and Betty Moore Foundation. 1. Chiribiquete-Caqueta; 2. Yasuni-Pastaza; 3. Yavari-Samiria; 4. Ampiyacu; 5. Upper Purus; 6. Madidi-Tambopata; 7. Itenez-Rondonia; 8. Calha Norte; 9. Xingu; 10. Lower Rio Negro; 11. Upper Rio Negro; 12. Madeira 


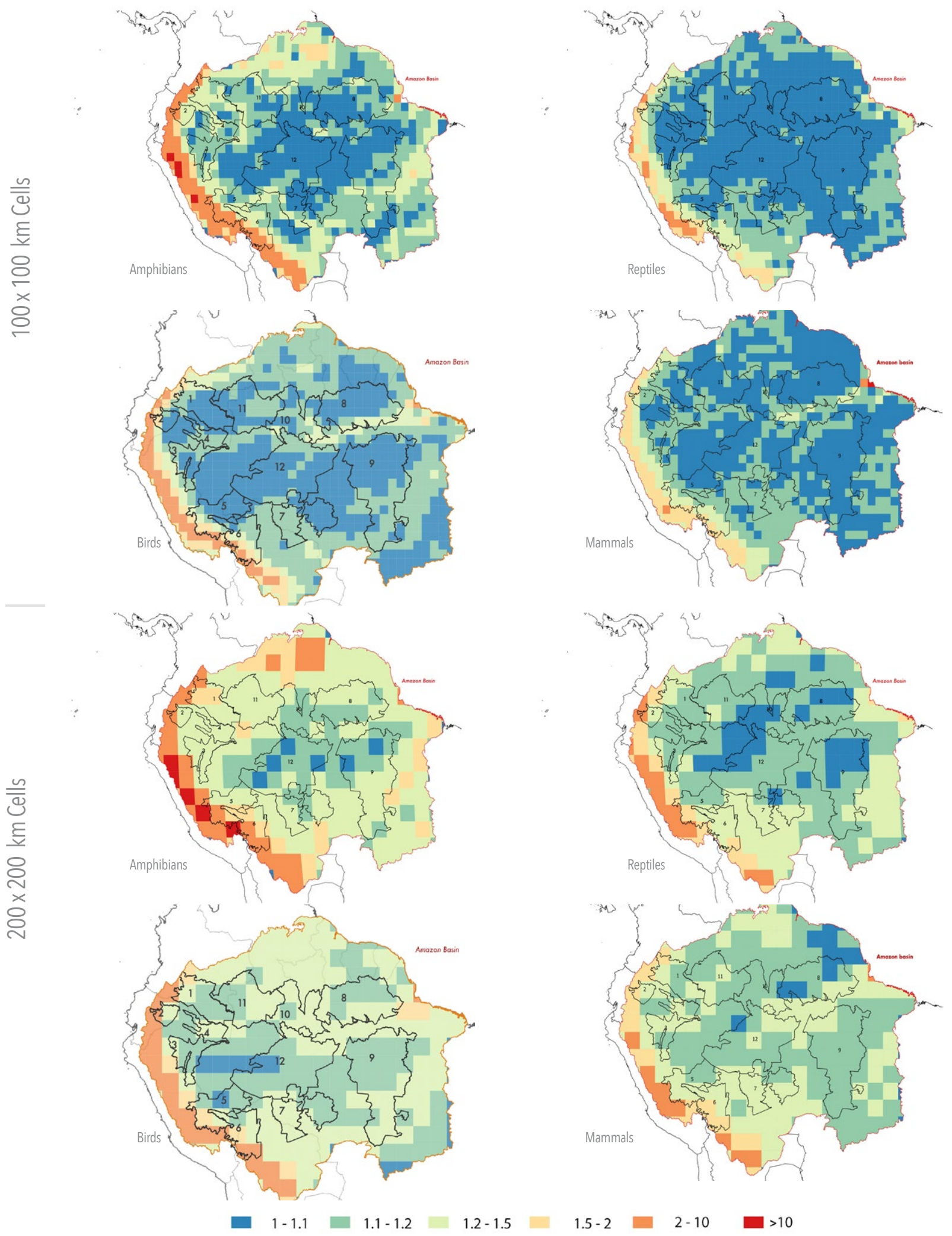

Figure 13 (cont.). Geographic patterns of beta-diversity ( $\boldsymbol{\beta}$ ) following Whittaker (1960) for amphibians, reptiles, birds and mammals at different spatial scales in the Amazon basin and twelve conservation mosaics supported by the Gordon and Betty Moore Foundation. 1. ChiribiqueteCaqueta; 2. Yasuni-Pastaza; 3. Yavari-Samiria; 4. Ampiyacu; 5. Upper Purus; 6. Madidi-Tambopata; 7. Itenez-Rondonia; 8. Calha Norte; 9. Xingu; 10. Lower Rio Negro; 11. Upper Rio Negro; 12. Madeira 
biological communities tend to differ too, and these changes

can be accentuated by other natural barriers, such as rivers,

mountains, or soil types, or indeed anthropogenic factors

such as forest fragmentation or variations in vegetation cover

(Moreno 2001).

These analyses are relevant for conservation efforts as specific environmental variables can be used to predict beta-diversity,

for example climate and temperature effects (Rodriguez et

al. 2019), as well as predict the effects of climate change on

the vertebrate groups studied here. For now these results

help to highlight the conservation mosaics with high and

intermediate beta-diversity for terrestrial vertebrates: Madidi-

Tambopata, Upper Purus, Yasuni Pastaza, Chiribiquete-

Caqueta, and small parts of Calha Norte, Yavari-Samiria, Lower Rio Negro, Lower Rio Negro and Xingu. For amphibian beta diversity the same eight conservation mosaics are the most important, and for reptiles the highest values were for Madidi-Tambopata, Upper Purus, Yasuni Pastaza and a small part of Yavari-Samiria. Birds have high and intermediate betadiversity in Madidi-Tambopata, Upper Purus, Yasuni-Pastaza, Yavari-Samiria, Chiribiquete-Caqueta and Calha Norte, and for mammals the highest values are in Madidi-Tambopata, Upper Purus, Yasuni-Pastaza, Chiribiquete-Caqueta and Calha Norte.
At the broader scales $(100 \times 100 \mathrm{~km} \& 200 \times 200 \mathrm{~km})$, the conservation mosaics with lowest beta-diversity $(\beta)$, were Madeira and Xingu for amphibians, Madeira, Xingu, Calha Norte and part of Lower Río Negro and Upper Río Negro for reptiles, Madeira, part of Yavari-Samiria and Upper Purus for birds, and Calha Norte, Madeira and part of Lower Rio Negro for mammals. It is important to note that for the finer scale analyses ( $25 \times 25 \mathrm{~km} \& 50 \times 50 \mathrm{~km})$, reptile beta-diversity estimates are especially limited by the available data (Roll et. al. 2017), although into the future the IUCN data also needs to be improved for amphibians and mammals.

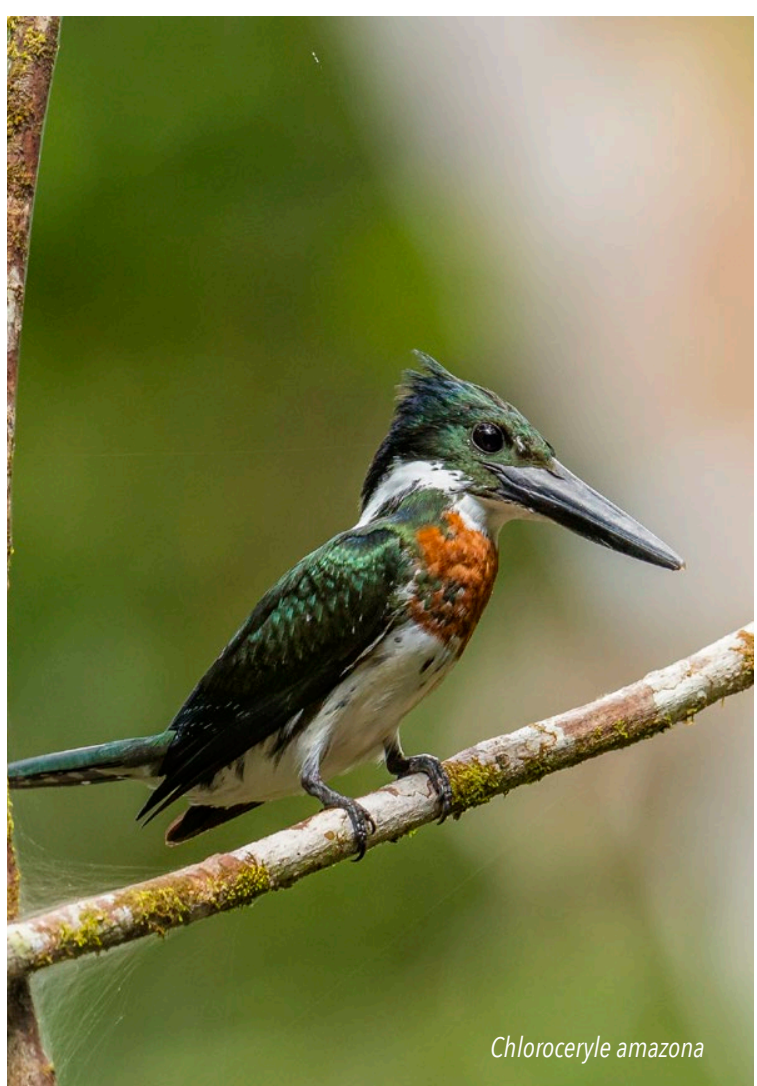


Contribution of protected areas and indigenous territories in the conservation of vertebrates in the Amazon basin

\section{i. Number of expected species for four vertebrate groups} in the protected areas and indigenous territories of the Amazon basin

Considering that 5,756 species of terrestrial vertebrates occur in the Amazon basin, we estimate that together National and Subnational Protected Areas (APs) and Indigenous Territories (TIs) host 5,449 amphibian, reptile, bird and mammal species. Birds have the highest number of expected species (2,454 species), followed by amphibians (1,188 species), then reptiles (947 species) and lastly mammals (860 species) (Figure 14).

We estimate that 5,183 of those species are found within the protected areas of the basin (Figure 14) including 2,386 species of birds, 1,058 species of amphibians, 893 species of reptiles and 846 species of mammals, showing a similar pattern to protected areas and indigenous territories combined.

The indigenous territories of the Amazon hold a total of 4,921 species of terrestrial vertebrates (Figure 14) including 2,334 species of birds, 939 species of amphibians, 848 species of reptiles and 800 species of mammals.

The existence of protected areas and indigenous territories is fundamental for effective biodiversity conservation (Maxwell et al. 2016; Schleicher et al. 2019), as they mitigate against the major threats of habitat destruction and contamination.

The quantity of terrestrial vertebrate species expected to occur in Protected Areas and Indigenous Territories in the Amazon basin by country ranges from 1,160 to 3,128 species (Figure 15). In general, high numbers of species are protected within the conservation units of all countries, especially Peru (3,128 species), Brazil (2,589 species), Bolivia (2,364 species), and Ecuador (2,263 species), while other countries (Venezuela, Guyana, Suriname and French Guiana), protect between 1,160 and 1,667 species in their conservation units (Figure 15).

National and subnational protected areas in the Amazon basin protect 2,863 species in Peru, 2,495 species in Brazil, 2,342 species in Bolivia, 2,097 species in Colombia, 2,202 species in Ecuador 1,643 species in Venezuela, 1,296 species in Guyana, 1,180 species in Suriname and 1,157 species in French Guiana (Figure 15).

Indigenous territories contain between 1,132 species of terrestrial vertebrates in French Guiana and 3,038 species in Peru (Figure 15). In general, species numbers within indigenous territories in each country, present similar patterns to indigenous territories and protected areas combined, with Peru, Brazil, Ecuador, Colombia and Bolivia, having the highest numbers. It is also worth highlighting that the indigenous territories of Colombia, 


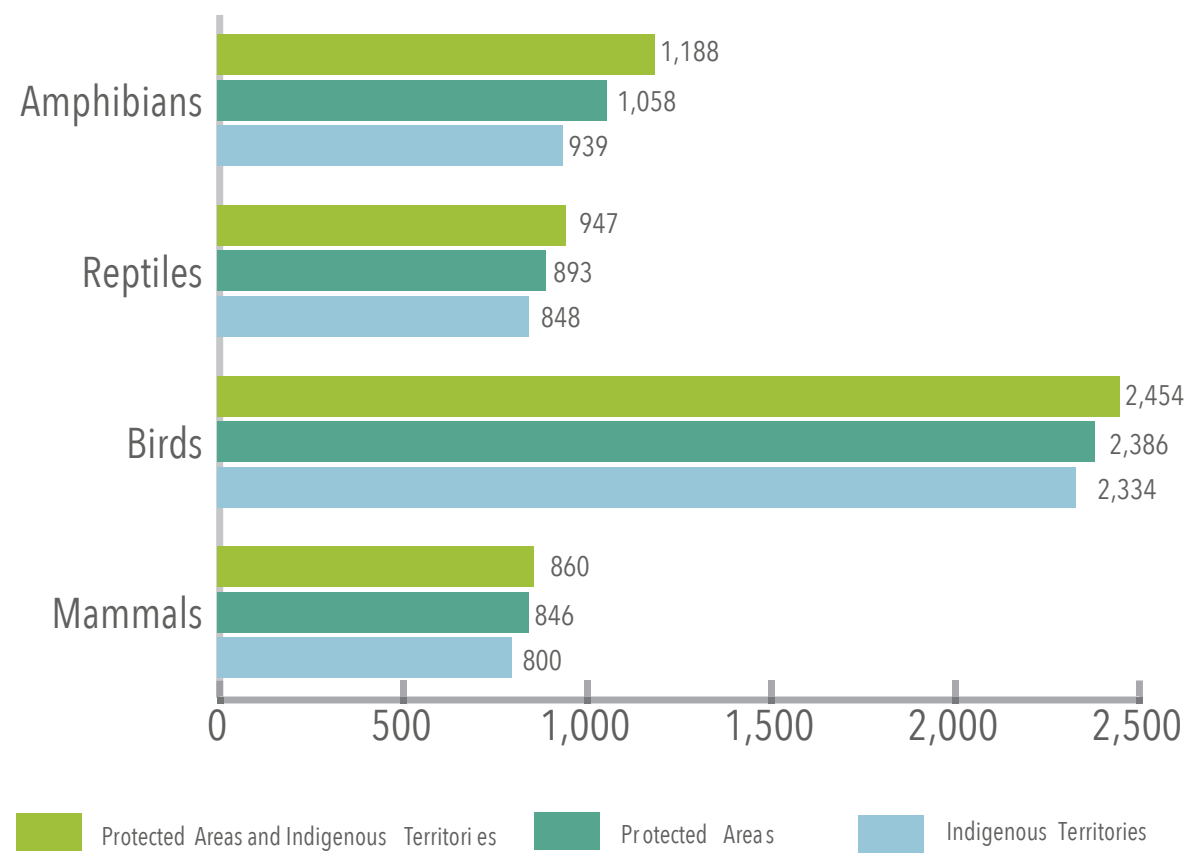

AMPHIBIANS, REPTILES, BIRDS AND MAMMALS

Protected Areas and

Indigenous Territories

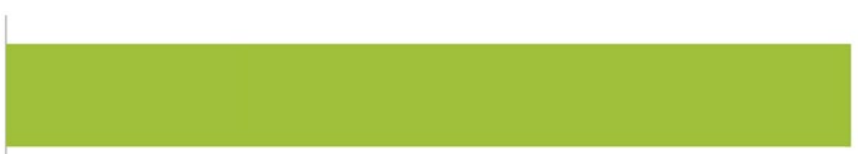

5,449

Protected Areas

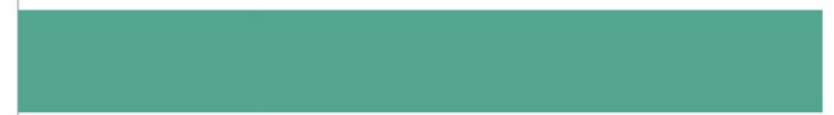

5,183

Indigenous
Territories

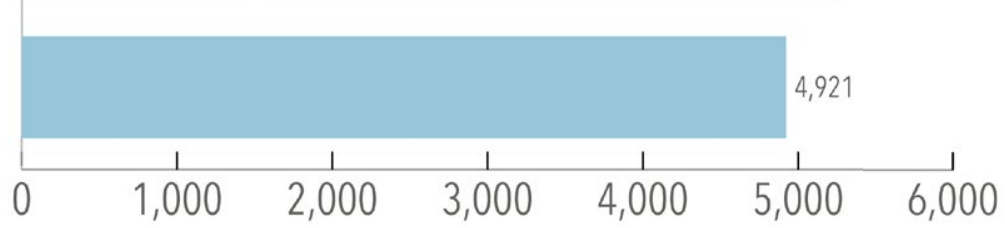

Protected Areas and Indigenous Territori es

Protected Areas

Indigenous Territories

Figure 14 : Estimated number of terrestrial vertebrate species in conservation units (Protected Areas, Indigenous Territories, and both categories combined) 


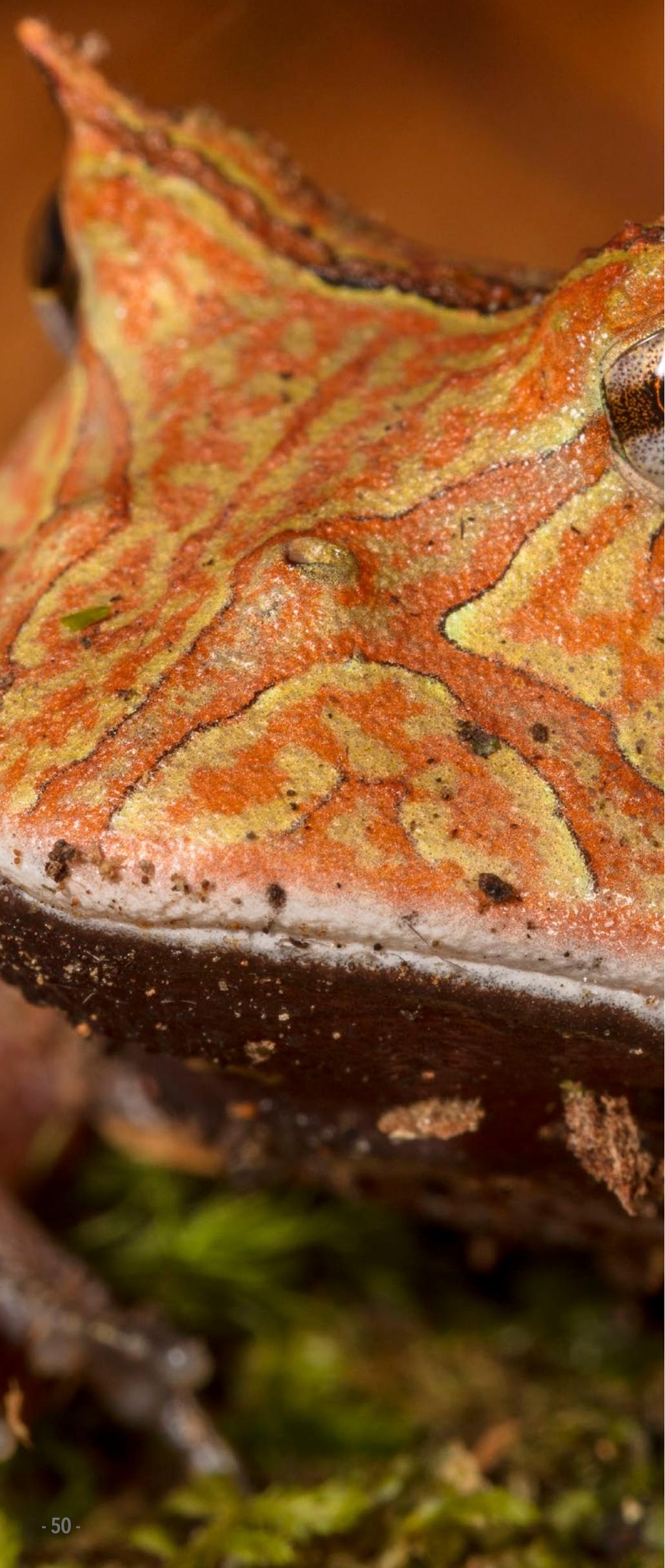


Guyana, Peru, Suriname and Venezuela hold more species than the protected areas in those countries (Figure 15).

Birds have the highest number of species within the protected areas and indigenous territories of the Amazon in all countries, ranging between 681 species in French Guiana and 1,653 species in Peru (Figure 15), with higher numbers in Bolivia, Colombia, Ecuador and Brazil, and less than 931 species in other countries. This pattern is typical for each vertebrate group with most reptile species in Brazil (444 species) and Peru (448 species), and most amphibians in Peru (547 species), Brazil (410 species) and Ecuador (370 species).

Protected areas and indigenous territories harbor most mammal species in Brazil (510 species), Peru (471 species) and Bolivia (397 species). Again, surprisingly indigenous territories harbor more mammal species than protected areas in Peru, Colombia, Venezuela and Guyana.

In general, protected areas protect more terrestrial vertebrate species than indigenous territories (Figure 15) with more species in countries with most Amazonian area like, Brazil, Bolivia and Colombia. Nevertheless, indigenous territories in Ecuador protect more amphibian and reptile species than protected areas. Indeed for reptiles this is the case in five of the nine countries. For birds, Indigenous Territories are potentially more important than Protected Areas in four countries: Peru, Venezuela, Guyana and Suriname (Figure 15). Here it is important to note that according to RAISG (2019) Protected Areas cover $11.9 \%\left(930,000 \mathrm{~km}^{2}\right)$ of the Amazon, whereas Indigenous Territories cover $28.1 \%\left(2,190,000 \mathrm{~km}^{2}\right)$. 
Amphibians

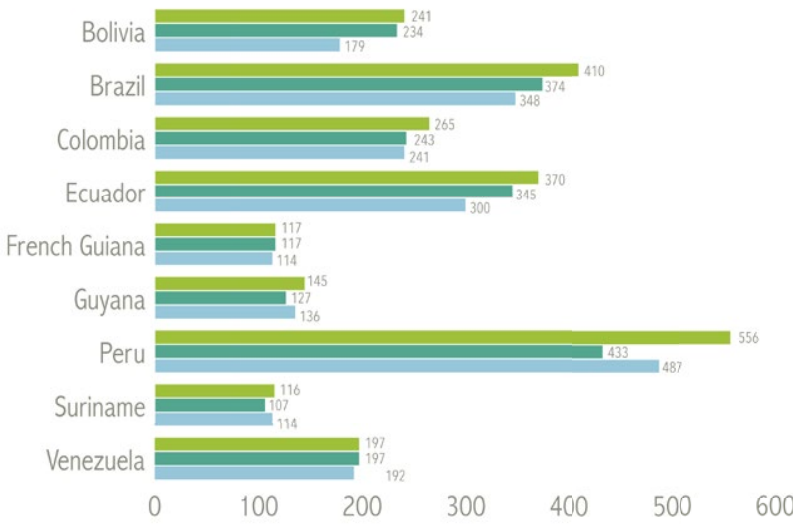

Birds

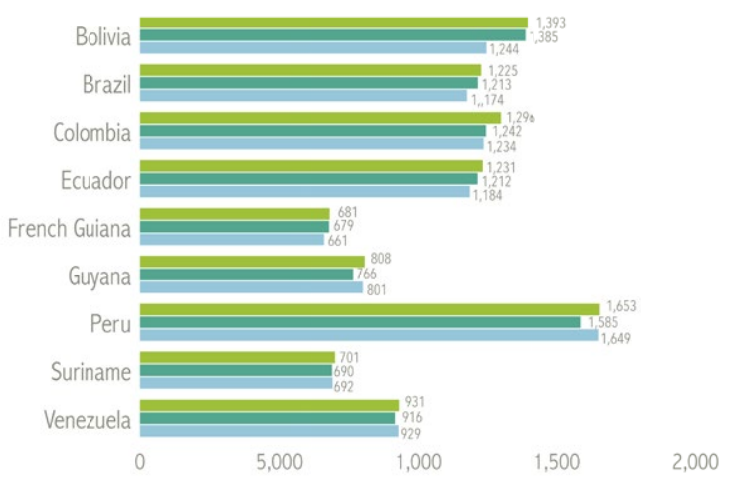

Reptiles

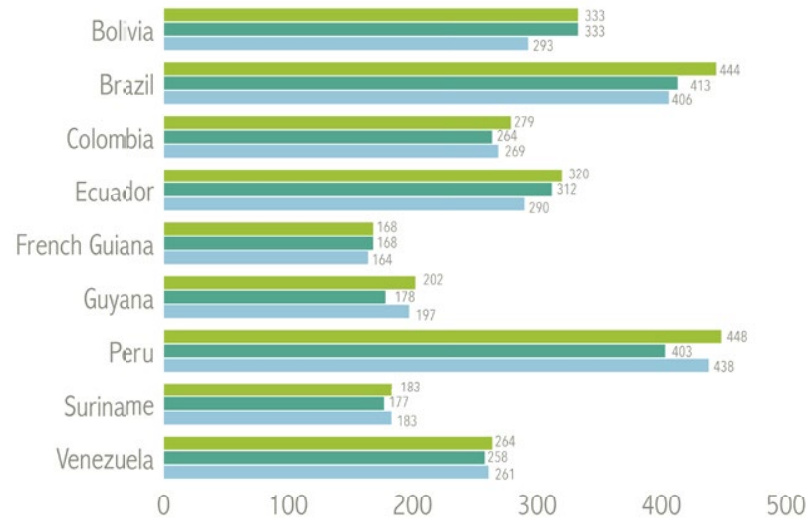

Mammals

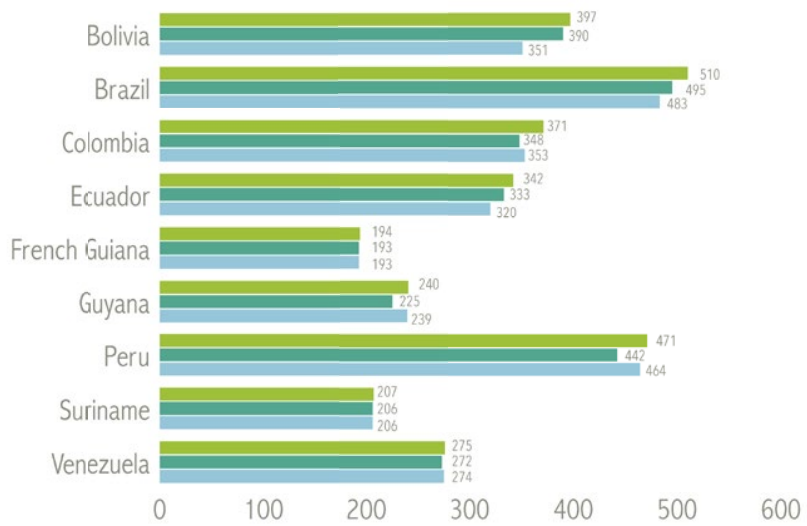

Protected Areas and Indigenous Territories

Protected Areas

Indigenous Territories

Figure 15: Estimated number of terrestrial vertebrate species in conservation units (Protected Areas, Indigenous Territories, and both categories combined) by country. 


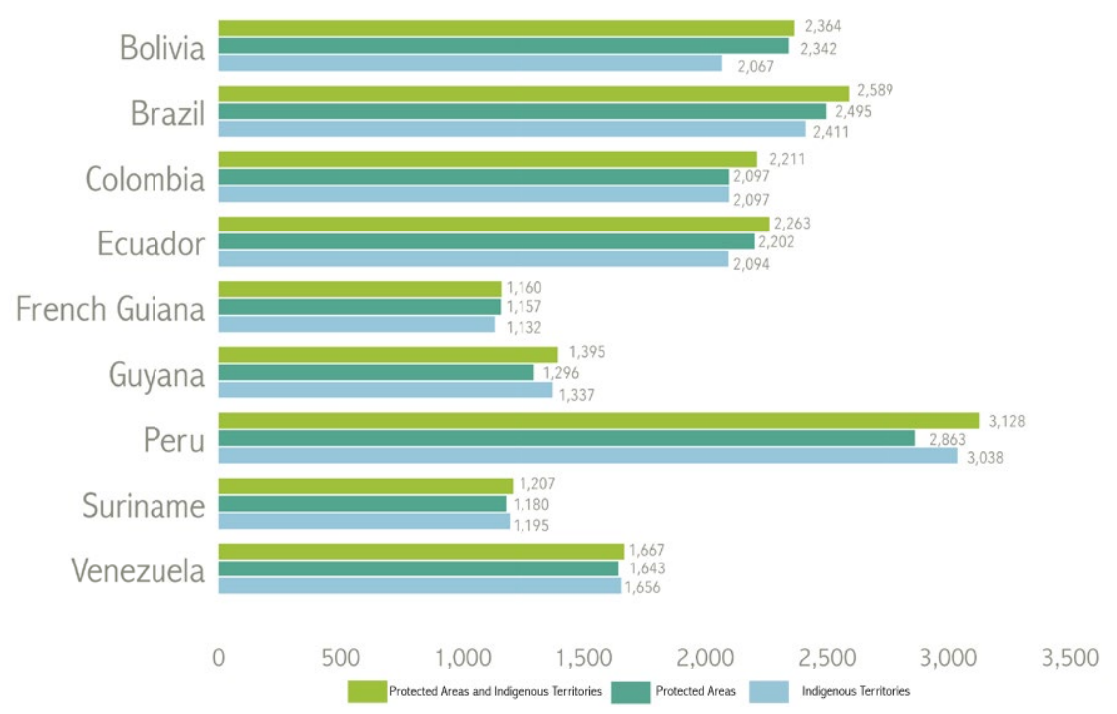

Figure 15 (cont.): Estimated number of terrestrial vertebrate species in conservation units (Protected Areas, Indigenous Territories, and both categories combined) by country.

ii. Representativeness of vertebrate species in Protected Areas and Indigenous Territories in the Amazon basin

We estimate that 5,449 species of amphibians, reptiles, birds and mammals are found within the National and Subnational Protected Areas (APs) and Indigenous Territories (TIS) of the Amazon basin, representing $94.67 \%$ of all terrestrial vertebrates in the Amazon (5,756 species), $53.91 \%$ of South America's $(10,108$ species $)$ and $14.92 \%$ of the world's terrestrial vertebrates (36,513 species) (Figure 16). Together the conservation units protect more than $94 \%$ of the Amazon species of combined vertebrate group: $98.4 \%$ of mammals, $98.08 \%$ of birds, $91.94 \%$ of reptiles and $88 \%$ of amphibians (Figure 19).

The National and Subnational Protected Areas of the Amazon collectively protect 5,183 species of amphibians, reptiles, birds and mammals, representing $90.05 \%$ of all Amazonian species for these groups and more than $50 \%$ of South American species (Figure 16). Collectively, protected areas harbor $96.8 \%$ of mammals, $95.36 \%$ of birds, $78.37 \%$ of amphibians and $86.7 \%$ of reptiles found in the Amazon basin (Figure 16). This data demonstrates that collectively the protected areas of the Amazon protect the vast majority of vertebrate biodiversity. Indeed, the protected area systems of the Amazon basin were developed with the implicit objective of protecting all Amazonian species (Schulman et al. 2007), which has become a more realistic goal given the recent tendency to expand the number of protected areas (Sala et al. 2000). Pringle (2017) suggests that despite management efforts many Protected Areas are poorly managed and ecologically damaged, often due to land titling conflicts and political corruption (Schleicher et al. 2019), or related to the time 
AMAZON

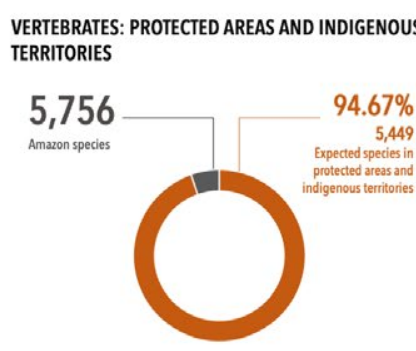

VERTEBRATES: PROTECTED AREAS

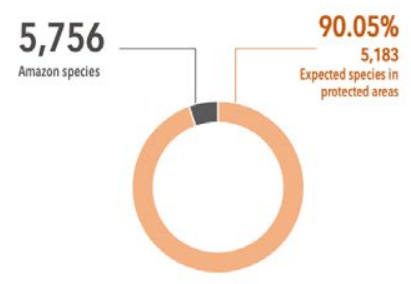

VERTEBRATES: INDIGENOUS TERRITORIES

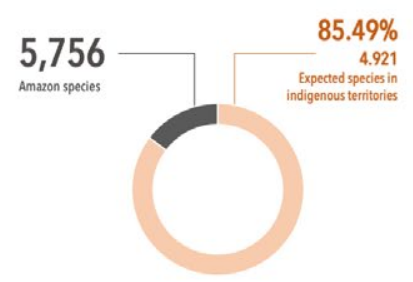

SOUTHAMERICA
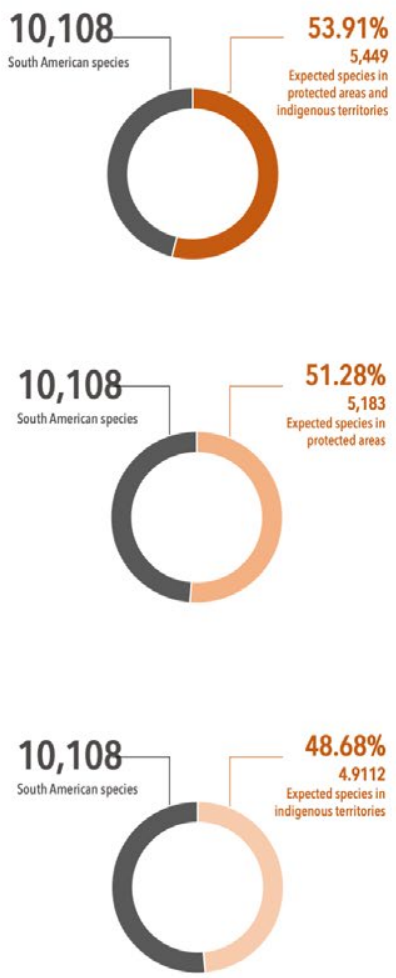

WORLD
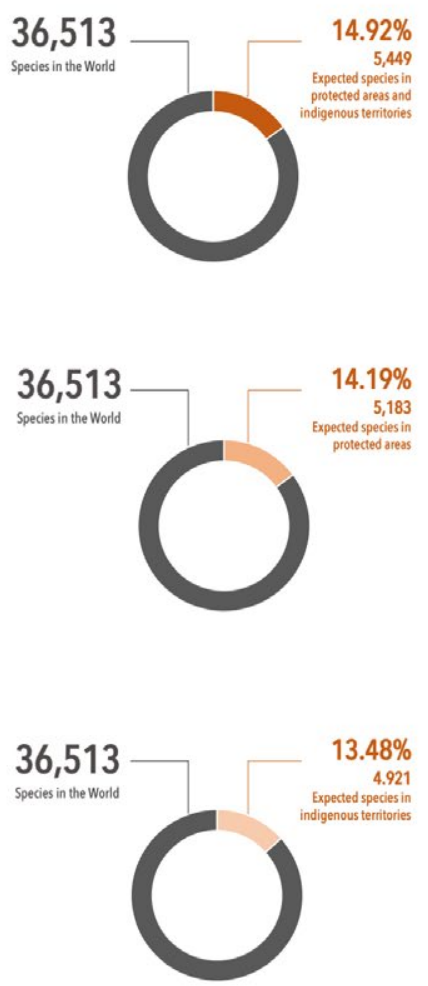

Figure 16: Representativeness of vertebrate diversity in conservation units: 1) Protected Areas and Indigenous Territories combined, 2) Protected Areas, 3) Indigenous Territories (compared with the number of species in the Amazon basin, South America and the world).

since their creation (Oliveira et al. 2017). Nevertheless, Schleicher

et al. (2019) demonstrated that protected area implementation,

especially stricter categories, help to reduce deforestation and

degradation rates, directly attributable to control, vigilance and management, and other important factors.

The Indigenous Territories of the Amazon are also important for biodiversity conservation harboring 4,921 amphibian, reptile, bird and mammal species, representing $85.49 \%$ of the Amazon's, $48.68 \%$ of South America's and $13.48 \%$ of the world's terrestrial vertebrate species (Figure 16). The representativeness analysis for each taxonomic group in indigenous territories indicate they are protecting 2,334 birds, 939 amphibians, 848 reptiles and 800 mammals, representing $69.56 \%$ of Amazonian amphibians, $82.33 \%$ of reptiles, $93.29 \%$ of birds, and $91.53 \%$ of mammals. Thus, $14.51 \%$ of vertebrate species are not expected in Indigenous Territories, and $9.95 \%$ of vertebrate species are not expected in Protected Areas, but amazingly only 5.33\% of Amazonian vertebrates are not expected to occur in existing Protected Areas or Indigenous Territories. The Protected Areas 
and Indigenous Territories cover $28 \%$ and $23.4 \%$ of the Amazon which covers 8,475,046 $\mathrm{km}^{2}$ (RAISG 2019), and these units are evidently crucial for global biodiversity conservation.

Terrestrial vertebrate representativeness by country provides another lens with which to examine the effectiveness of the conservation units in the Amazon. For example, Protected Areas and Indigenous Territories in most countries contain more than $70 \%$ of the Amazonian species in each country (Figure 17), especially in the smaller countries such as Suriname (98.69\%), Guyana (98.31\%) and French Guiana (96.11\%) that are entirely found within the Amazonian basin (RAISG 2019). The Guinean Shield has a large quantity of endemic species and encouragingly almost all of them are found within at least one conservation unit. This situation holds true when analyses are broken down for each vertebrate group, for example, almost $100 \%$ of amphibian, reptile and mammal species in Suriname and French Guiana are found within Protected Areas and Indigenous Territories (Figure 18). Conservation units in Guyana protect $100 \%$ of bird species, whereas Suriname units protect $98 \%$ of birds, and in French Guiana units protect $94 \%$ of birds (Figure 18). This is especially impressive given the relatively small areas covered by Protected Areas $\left(10,357\right.$ to $\left.61,794 \mathrm{~km}^{2}\right)$ and Indigenous Territories $\left(7,068\right.$ to $\left.31,671 \mathrm{~km}^{2}\right)$ as compared to other countries, although Protected Areas cover $73.4 \%$ of French Guiana (RAISG 2019). These results suggest that protected area design has been extremely effective, complimented by commitments to indigenous people (RENFORESAP 2018). Indeed, French Guiana and Suriname have a high number of stricter protection Protected Areas, and in Suriname $72,000 \mathrm{~km}^{2}$ of pristine tropical

\section{Amphibians, reptiles, birds and mammals}

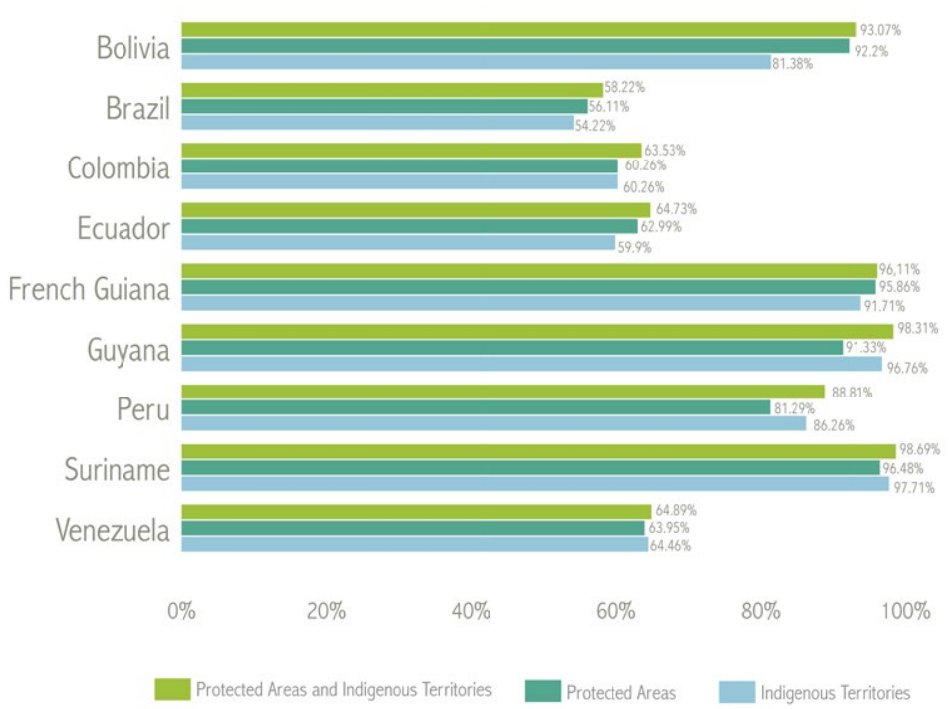

Figure 17. Representativeness of vertebrate diversity in conservation units by country for Protected Areas and Indigenous Territories combined, Protected Areas and Indigenous Territories (compared with the total number of vertebrate species by country). 
forest were planned for conservation efforts (RedParques 2018), as

well as a project to integrate the countries of the Guinean Shield improving management capacities, so as to increase the resilience of the forest and livelihood options of local people in a context of global climate change (RENFORESAP 2018).

The western Amazon in Bolivia, Colombia, Ecuador, Peru, and part of Brazil has the highest concentrations of terrestrial vertebrates in South America, and also have high percentages of this biodiversity expected to occur within Protected Areas and Indigenous Territories (Figure 17). Notably in Bolivia 93.07\% of Amazonian terrestrial vertebrate species are found in these conservation units and in Peru this figure is $88.81 \%$. This breakdown holds true for most of the individual vertebrate groups with $97 \%$ of Amazonian birds expected to occur in at least one Protected Area or Indigenous Territory in Bolivia and 88\% for Peru (Figure 18). Similarly, $92 \%$ of Amazonian mammals are expected to occur in at least one Protected Area or Indigenous Territory in Bolivia and $91 \%$ for Peru. For amphibians $86 \%$ and reptiles $86 \%$ of Amazonian species are expected to occur in at least one Protected Area or Indigenous Territory in Bolivia, and in Peru $89 \%$ of amphibians and $90 \%$ of reptiles. Together these figures suggest that collectively the protected area and indigenous territory capital in the Bolivian and Peruvian Amazon have been placed in a strategic and efficient manner. 


\section{Amphibians}

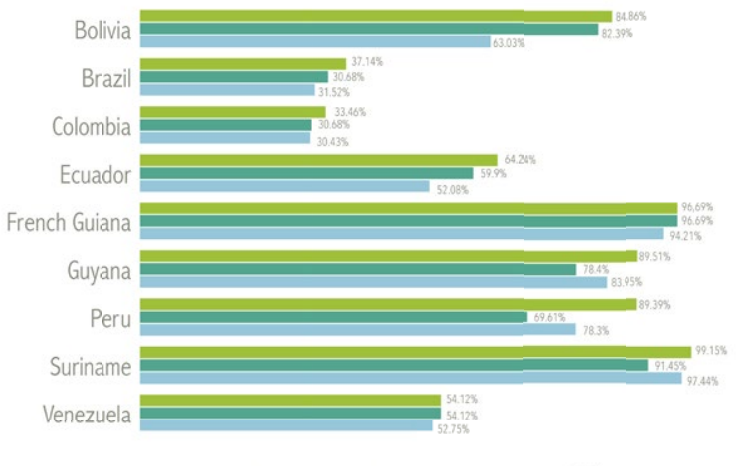

$\begin{array}{llllll}0 \% & 20 \% & 40 \% & 60 \% & 80 \% & 100 \%\end{array}$

Birds

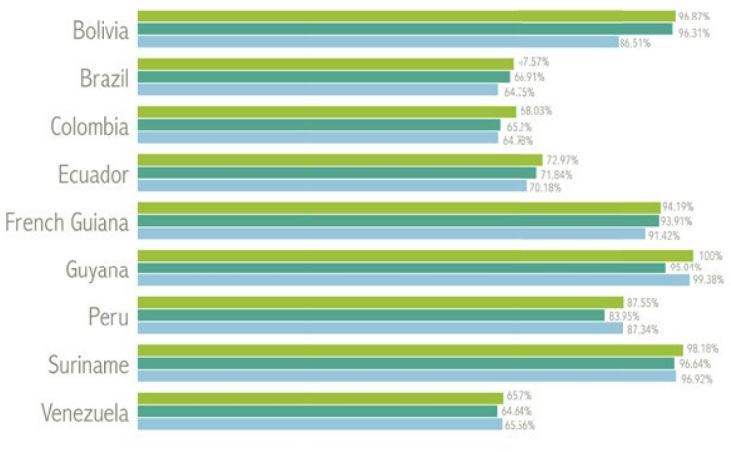

$\begin{array}{llllll}0 \% & 20 \% & 40 \% & 60 \% & 80 \% & 100 \%\end{array}$
Reptiles

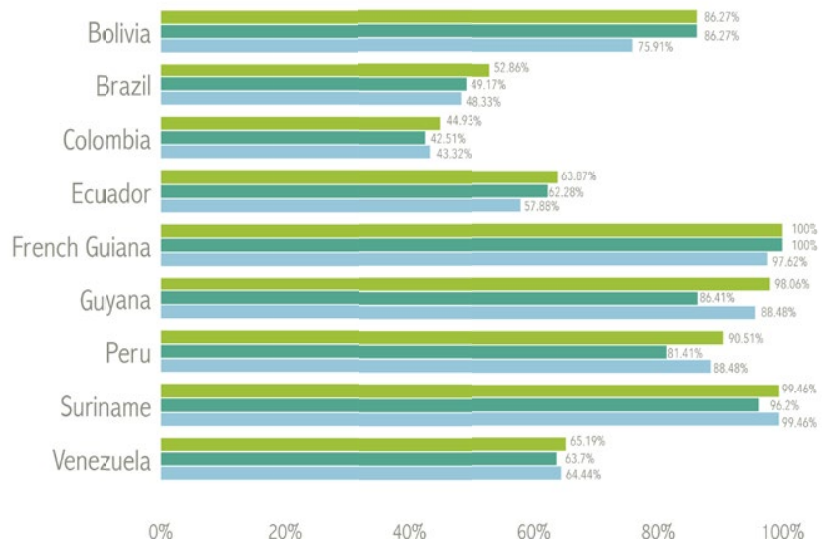

Mammals

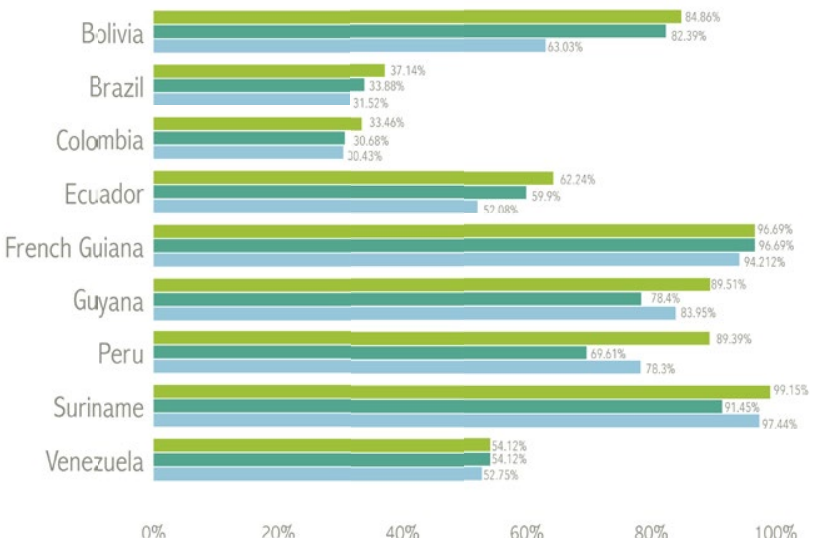

Protected Areas and Indigenous Territories

Protected Areas

Indigenous Territories

Figure 18: Representativeness of amphibians, reptiles, birds and mammals diversity in conservation units for Protected Areas and Indigenous Territories combined, Protected Areas and Indigenous Territories (compared with the total number of vertebrate species by country). 
Peru has recently increased the number and area in conservation units (RENFORESAP 2018), with a relatively large area in Protected Areas $\left(202,865 \mathrm{~km}^{2}\right)$ and the largest number of Indigenous Territories in the Amazon covering $322,255 \mathrm{~km}^{2}$ (RAISG 2019). Gullison and Hardner (2018) attribute this increase to significant political will and the correct designation of land towards conservation, along with improved capacity in governmental and non-governmental actors. In Bolivia, Protected Areas cover 207,227 km² and Indigenous Territories 187,431 km² (RAISG 2019), with relatively few, yet large, National Protected Areas, although few have been created since the end of the 20th Century. Non-governmental organizations have been especially important in providing technical support to Indigenous Territories, for example, the Tacana and Tsimane' have developed unparalleled capacity in the Amazon for the successful and sustainable management of natural resources (Gullison \& Hardner 2018).

Thanks to the Protected Areas and Indigenous Territories deforestation and forest degradation rates in Peru have been relatively low (Blackman et al. 2017, Schleicher et al. 2017), further supporting the regional trend of low deforestation rates within Indigenous Territories(RAISG 2016; Blackman etal. 2017), stressing their importance towards biodiversity conservation in the Amazon. Bolivia and Peru have increased formally titled Indigenous Territory coverage, with more expected to be formally 
recognized in years to come (Gullison \& Hardner 2018).

In contrast the representativeness values for Amazonian terrestrial vertebrates within Protected Areas and Indigenous Territories in Brazil, Colombia, Ecuador and Venezuela are significantly lower at less than $63.5 \%$ in Colombia, $64.8 \%$ in Venezuela, $64.7 \%$ in Ecuador and lowest in Brazil at 58.2\% (Figure 17). This analysis also contrasts with the total number of species in Protected Areas and Indigenous Territories in Brazil, which is very high, especially for reptiles and mammals (Figure 15). The Brazilian Amazon covers 5,239,647 km² representing 61.5\% of the country (RAISG 2019), including by far the greatest portion of the Amazon basin, and with 19.8\% or $1,037,074 \mathrm{~km}^{2}$ dedicated to Protected Areas and $22.2 \%$ or $1,156,900 \mathrm{~km}^{2}$ to Indigenous Territories. The overall size of the Amazon in Brazil may best explain the lower percentages of Amazonian biodiversity in protected areas, and this pattern holds true for the individual vertebrate groups, with extremes of just $37.14 \%$ of Amazonian amphibians in Brazil found within the Protected Areas and Indigenous Territories, and $52.86 \%$ of reptiles.
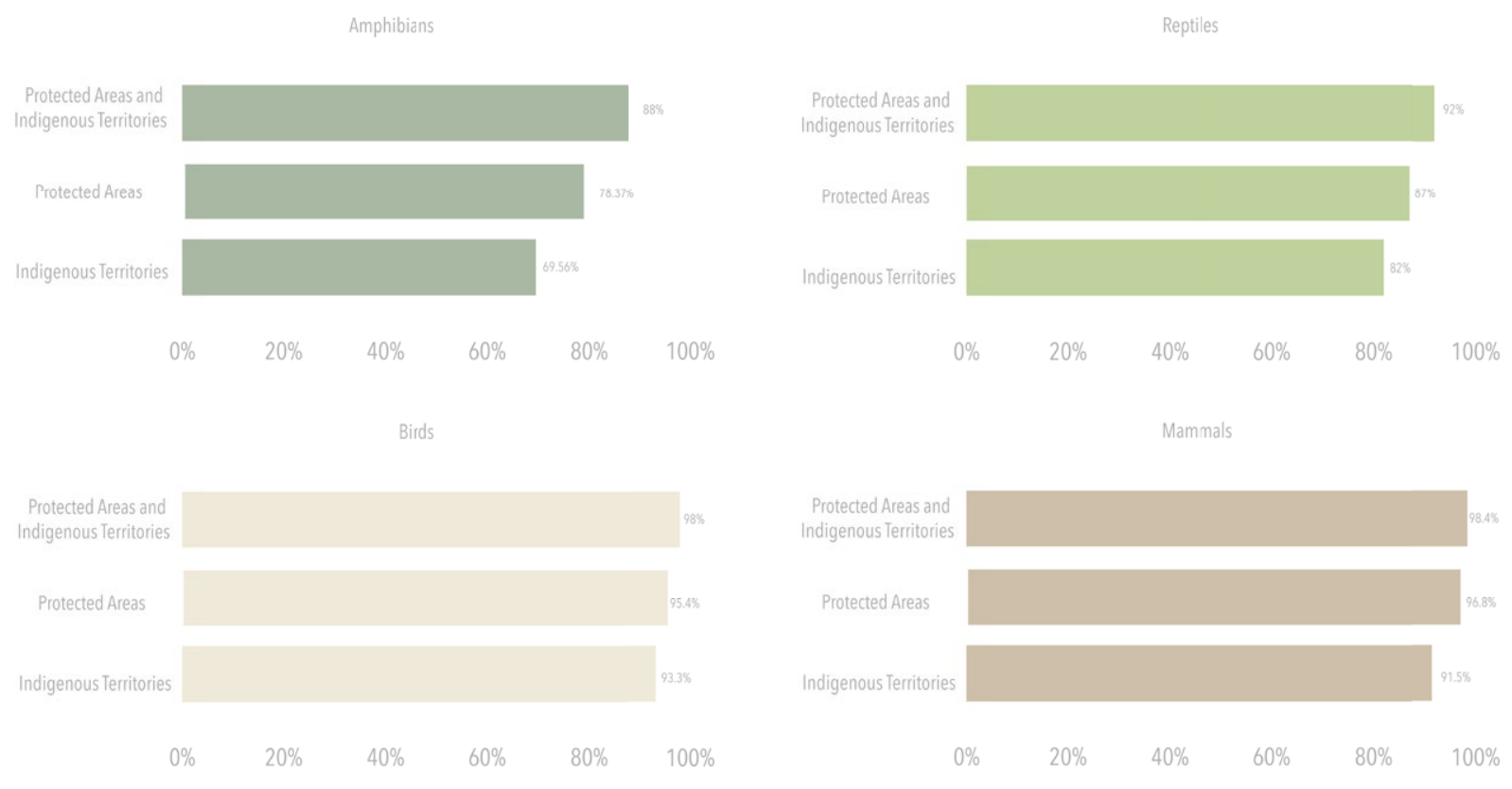

Figure 19: Representativeness of amphibians, reptiles, birds and mammals in the Amazon basin in Protected Areas (National and Subnational), Indigenous Territories and Protected Areas and Indigenous Territories combined. 
Possibly the high deforestation rates in large parts of the Brazilian Amazon (INPE 2012; Oliveira et al. 2017; González et al. 2018; Gomes et al. 2019) may have limited protected area creation and indigenous territory recognition, for example, in southeastern Amazonian Brazil along the Arc of Deforestation. Furthermore, deforestation projections into the future in central and eastern Amazonian Brazil are significant, as are the risks of drought (Soares et al. 2006; Malhi et al. 2008; Gomes et al. 2019).

Mammals and birds have the lowest levels of representativeness in Protected Areas and Indigenous Territories of Venezuela, Brazil, Colombia and Ecuador: 66\% of Amazonian birds in Venezuela, $68 \%$ in Brazil and Colombia, and $73 \%$ in Ecuador, and $86 \%$ of Amazonian mammals in Ecuador, $72 \%$ in Venezuela and $74 \%$ in Brazil and Colombia. The Protected Areas and Indigenous territories of Ecuador protect $64 \%$ of the country's Amazonian reptile and amphibians. Eastern Ecuador and northern Peru are the only parts of South America where the centers of species richness overlap for the four vertebrate groups (Bass et al. 2010).

The representativeness of Amazonian vertebrates in Venezuela is also striking in a country with large extensions of Protected Areas $\left(249,109 \mathrm{~km}^{2}\right)$ and Indigenous Territories $\left(326,521 \mathrm{~km}^{2}\right)$, larger than Bolivia and Peru (RAISG 2019). Colombia also has relatively low representativeness values and the third most endemic species (Swenson 2001), suggesting a need for a new phase of protected area creation in the Colombian Amazon. However, the possibilities for new protected area creation in Ecuador, Venezuela, Colombia and Brazil maybe limited by a proliferation of threats such as hydroelectric dams, mining, mechanized agriculture and intensive livestock expansion, hydrocarbon exploitation, or other extractive industries (Finer et al. 2008; Kröger \& Lalander, 2016; Latrubesse et al. 2017; González et al. 2018). For example, the renowned Yasuni National Park is the largest Protected Area in the Ecuadorian Amazon covering $14 \%$ of the Ecuadorian Amazon, whereas hydrocarbon concessions cover 79\% (Bass et al. 2010). The western Amazon is also threatened by hydrocarbon extraction in Colombia, Peru, Brazil and Bolivia (Finer et al. 2008).

Several authors have argued for the expansion of the Protected Area and Indigenous Territory capital in the Amazon to increase representativeness, protect significant portions of threatened and endemic species, improve climate change adaptation, increase connectivity and landscape permeability for species or ecosystems through the creation of corridors or restoration of fragments, or promote sustainable use of land and resources to ensure biological flow (Da Silva et al. 2005; Schulman et al. 2007; Gonzalez et al. 2018; RENFORESAP 2018; Metzger et al. 2019). The lower levels of representativeness for amphibians and reptiles is explained by their relatively small distributional ranges, 
especially amphibians, which results in lower concentrations at few places (Jenkins et al. 2013), and it is therefore difficult to capture total diversity in Protected Areas.

Nevertheless, the National Protected Areas of the nine countries of the Amazon basin have the highest representativeness of species for the four vertebrate groups (Figure 18). Protected Areas were more important than Indigenous Territories for amphibians in all nine countries. Nevertheless, six countries (Peru, Guyana, French Guiana, Colombia, Suriname and Venezuela) have higher mammal representativeness in Indigenous Territories, three countries (Peru, Guyana and Suriname) have higher reptile representativeness in Indigenous Territories, and four countries (Peru, Guyana, Venezuela and Suriname) have higher bird representativeness in Indigenous Territories.

Beyond the examples in Peru and Bolivia, there are several other recent studies that demonstrate that Indigenous Territories and sustainable management efforts reduce deforestation rates and protect high levels of biodiversity (Nepstad et al. 2006; Schleicher et al. 2017; Schuster et al. 2019). Indeed, indigenous people are actively defending their lands from incursions from third parties including agriculture (Nepstad et al. 2006). For example, the Kayapo people have successfully defended their ancestral lands from colonists and cowboys trying to invade their territory (Zimmerman et al. 2001), maintaining deforestation rates close to zero (Schwartzman et al. 2000; Zimmerman et al. 2001).

In part, the importance of the Indigenous Territories can be explained by the fact that they are more numerous than Protected (RAISG 2019), for example, in Brazil there are 140 Amazonian Protected Areas, but more than 350 Indigenous Territories (RAISG 2019). Peru has more than 2,500 Indigenous Territories, although they tend to be rather small in comparison with those in other countries in the Amazon.

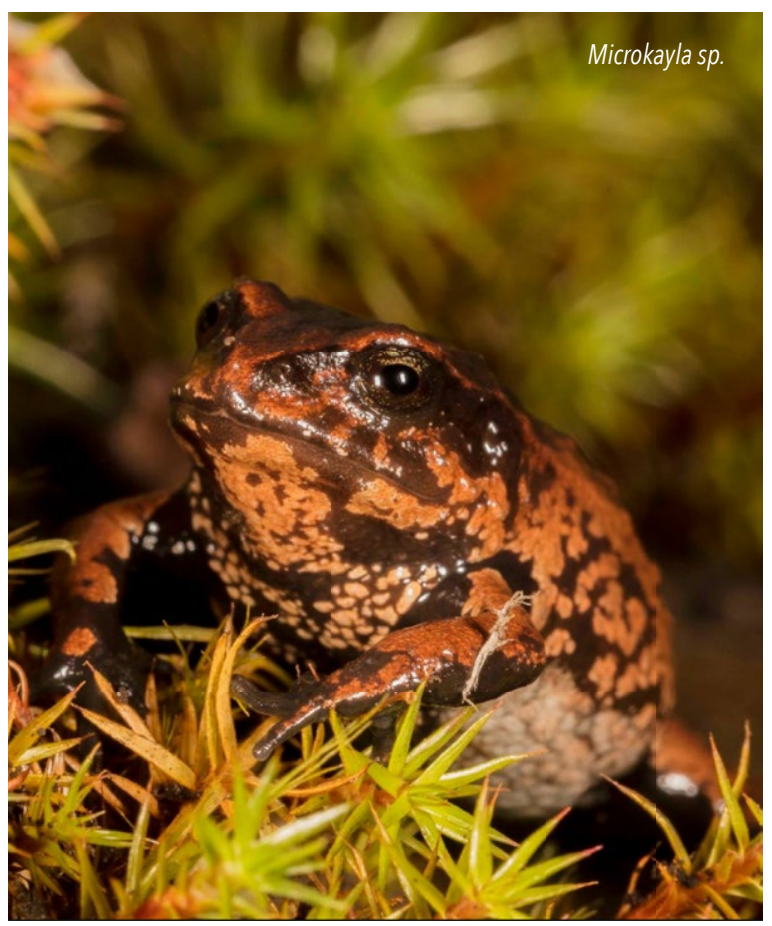


Complementarity analyses for species diversity in Amazon basin

The complementarity analysis for terrestrial vertebrates in the Amazon basin revealed that from the 254 cells in the region, a total of 112 cells would be necessary to include $100 \%$ of Amazonian amphibian species, 87 cells for $100 \%$ of Amazonian reptiles, 66 cells for $100 \%$ of Amazonian birds, and 46 cells for Amazonian mammals (Figure 20). The highlighted cells in the complementarity analysis for terrestrial vertebrates are spread amongst the nine countries of the Amazon basin, with cells running along the eastern slopes of the Andes mountain chain, as well as the mountainous zone of the northern Amazon, and lowland floodplain cells in the western, southern, eastern and central Amazon. Although this is the first study for the entire Amazon basin, many of the areas highlighted as important in this complementarity analysis were highlighted in our alphadiversity analysis, as well as in previous studies (Duellman 1999; Ceballos \& Ehrlich 2006; Jenkins et al. 2013; Roll et al. 2017; González et al. 2018).

A comparison of the selected cells in comparison with the distribution of National Protected Areas, Subnational Protected Areas and Indigenous Territories the majority of these complementarity cells when Protected Areas in general and

Figure 20: Complementarity analysis and efficient cell selection for maximum species richness for amphibians, reptiles, birds and mammals in the Amazon basin. 
Indigenous Territories are combined (Figure 21), once again highlighting the effectiveness of existing conservation units in biodiversity conservation. For each vertebrate group a few cells only partially overlapped with Protected Areas and Indigenous Territories (Figure 21), for example, five cells for amphibians $(93,81,59,15,10)$, six cells for reptiles $(65,8,7,4,2,1)$, six cells for birds $(400,120,100,86,12,10)$, and five cells for mammals $(89,76,26,22,13)$.

Comparing the highest value complementarity cells for each vertebrate group with the distribution of Protected Areas (National and Subnational) and then separately with the distribution of Indigenous Territories (Figure 22), showed that Protected Areas protect a greater quantity of priority cells than Indigenous Territories. For example, for amphibians, for 16 priority cells in southeastern and southern Amazonia there is no overlap with Indigenous Territories, whereas 10 priority cells in northern, southeastern and western Amazonia have no overlap with Protected Areas. For reptiles, birds and mammals there are up to seven priority cells that do not overlap with Protected Areas, as compared to between 7 and 15 cells that do not overlap with Indigenous Territories, principally in northern, western and southeastern Amazonia (13 priority bird cells with no overlap with Indigenous Territories and

Figure 21: Complementarity analysis and efficient cell selection for maximum species richness for amphibians, reptiles, birds and mammals in relation to the distribution of all Protected Areas and Indigenous Territories in the Amazon basin.
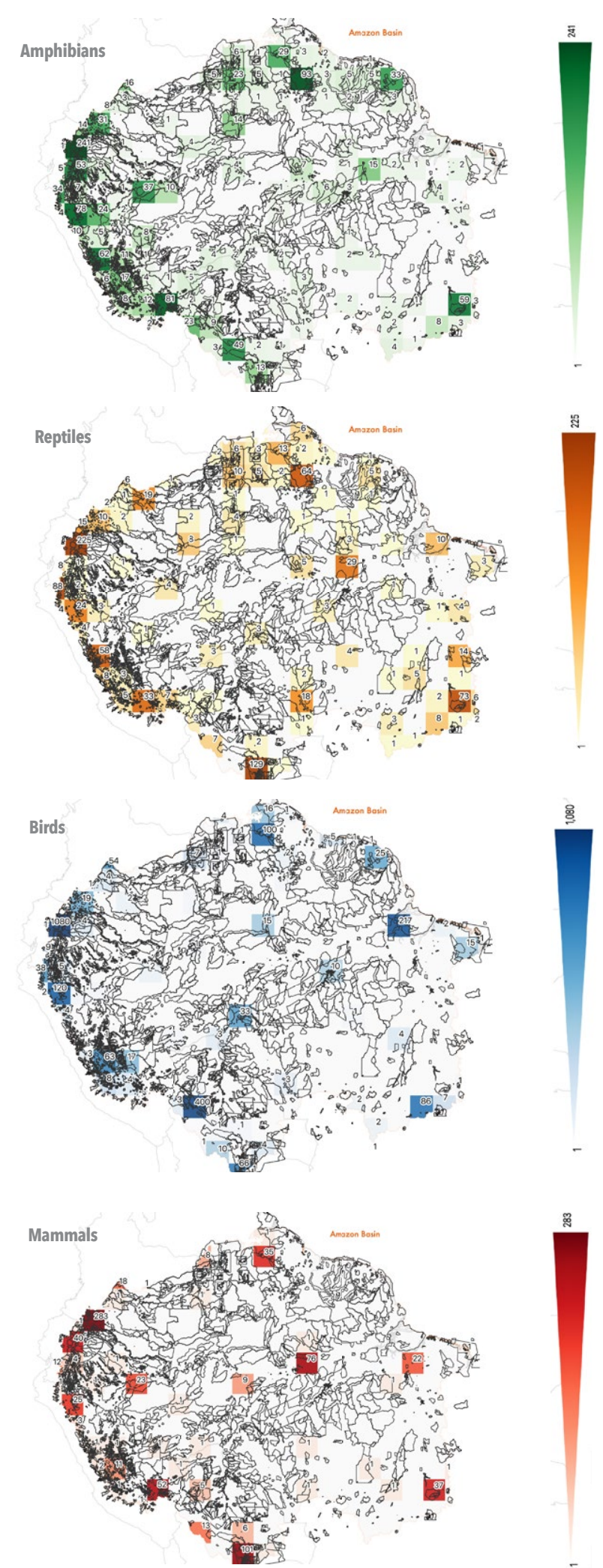

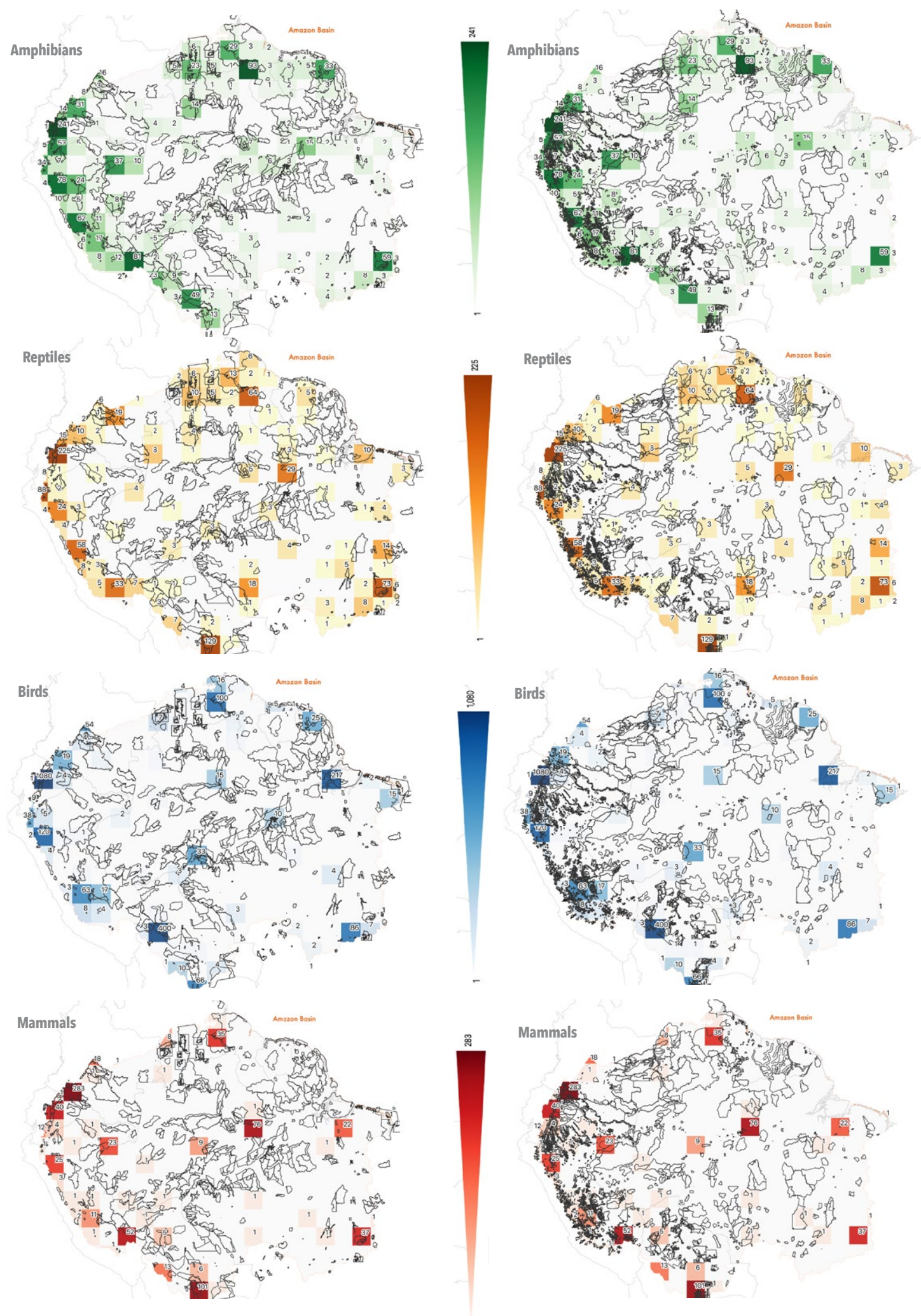

Figure 22: Complementarity analysis and efficient cell selection for maximum species richness for amphibians, reptiles, birds and mammals in relation to the distribution of National Protected Areas, Subnational Protected Areas and Indigenous Territories in the Amazon basin. 
seven not in Protected Areas; 15 priority reptile cells with no overlap with Indigenous Territories and seven not in Protected Areas; seven priority mammal cells not in Protected Areas and Indigenous Territories). A closer look at Colombia and Ecuador highlights the complementarity that the combination of Protected Areas and Indigenous Territories play in the conservation of terrestrial vertebrate diversity in the Amazon, where Protected Areas do not completely cover all of the highest priority complementarity cells, but adding in Indigenous Territories provides significantly better coverage (Figures 21-22). This pattern is relevant across the basin and is also reflected in our representativeness analyses (Figures 16-19).

An analysis of the contribution of National Protected Areas versus Subnational Protected Areas and Indigenous Territories revealed that National Protected Areas harbored most terrestrial vertebrate species (5,103 species), and the Subnational Protected Area and Indigenous Territory categories added further species not found in the National Protected Areas, 94 and 252 species respectively (Table 6). 
Table 6. Cumulative complementarity analysis for amphibians, reptiles, birds and mammals in National Protected Areas, Subnational Protected Areas and Indigenous Territories in the Amazon basin.

\begin{tabular}{|c|c|c|c|}
\hline Group & Spatial Unit Category & $\begin{array}{c}\text { Number of Additional } \\
\text { Species }\end{array}$ & $\begin{array}{c}\text { Cumulative Species } \\
\text { Richness }\end{array}$ \\
\hline \multirow{3}{*}{ Amphibians } & National Protected Areas & 1,013 & 1,013 \\
\hline & Subnational Protected Areas & 45 & 1,058 \\
\hline & Indigenous Territories & 130 & 1,188 \\
\hline \multirow{3}{*}{ Reptiles } & National Protected Areas & 870 & 870 \\
\hline & Subnational Protected Areas & 23 & 893 \\
\hline & Indigenous Territories & 54 & 947 \\
\hline \multirow{3}{*}{ Birds } & National Protected Areas & 2,386 & 2,386 \\
\hline & Subnational Protected Areas & 14 & 2,400 \\
\hline & Indigenous Territories & 54 & 2,454 \\
\hline \multirow{3}{*}{ Mammals } & National Protected Areas & 834 & 834 \\
\hline & Subnational Protected Areas & 12 & 846 \\
\hline & Indigenous Territories & 14 & 860 \\
\hline \multirow{3}{*}{ Vertebrates } & National Protected Areas & 5,103 & 5,103 \\
\hline & Subnational Protected Areas & 94 & 5,197 \\
\hline & Indigenous Territories & 252 & 5,449 \\
\hline
\end{tabular}

Whilst complementarity analyses serve as a useful baseline with which to establish conservation priorities into the future, they do not reflect ecological processes, or inform us about minimum viable populations of species (Jacinto-Flores et al. 2017). Complementarity analyses prioritize areas where many species overlap, sometimes considered ecological transition zones (Lombard 1995), and therefore, at least for a portion of species, perhaps not priority areas from a minimum viable population perspective, although this debate is ongoing (Araújo 2002; Kati et al. 2004). 


\section{CONCLUSIONS}

To conclude, the Protected Areas and Indigenous Territories of the Amazon cover almost half of the basin, representing a magnificent and globally unprecedented conservation achievement over the last three decades. This study underlines this poorly recognized contribution by demonstrating that from the perspective of biodiversity conservation, collectively this existing conservation collateral is estimated to include populations of almost $95 \%$ of terrestrial vertebrate species of the Amazon, $54 \%$ of terrestrial vertebrate species in South America and $15 \%$ of terrestrial vertebrate species worldwide. National and Subnational Protected Areas alone are expected to harbor 5,183 species of terrestrial vertebrates, amounting to $90 \%$ of terrestrial vertebrates in the Amazon. Similarly, indigenous Territories are expected to harbor 4,921 terrestrial vertebrate species, representing $85.49 \%$ of terrestrial vertebrates of the Amazon.

The analysis of representativeness at the country level also reveals that Protected Areas and Indigenous Territories in most Amazonian nations would house more than $70 \%$ of vertebrate species diversity, further underlining that the collective of Protected Areas and Indigenous Territories are located in strategic and efficient conservation sites. These analyses stress the importance of the sustainable management Protected Areas and Indigenous Territories into the future.

Overall these analyses underline the commitment that Amazonian nations have already made towards biodiversity conservation in the Amazon through the formal designation of Protected Areas across the basin, and the recognition of large areas as Indigenous Territories. Nevertheless, most of these conservation units are chronically underfunded and many are under threat from the development of the Amazon. Furthermore, recent studies suggest that between $60 \%$ and $80 \%$ of the Amazon's original forest cover must be retained in order to retain the climate regulation functions for the region (Lovejoy \& Nobre 2018). Thus, these results are also bittersweet. The protection of almost $95 \%$ of terrestrial vertebrate biodiversity is truly extraordinary, however, in the face of threats and the global climate change challenge in order to ensure this accomplishment a sustainable finance stream for the Protected Areas and Indigenous Territories of the Amazon must be established, as well as further mechanisms to increase the percentage of original forest cover under protection.

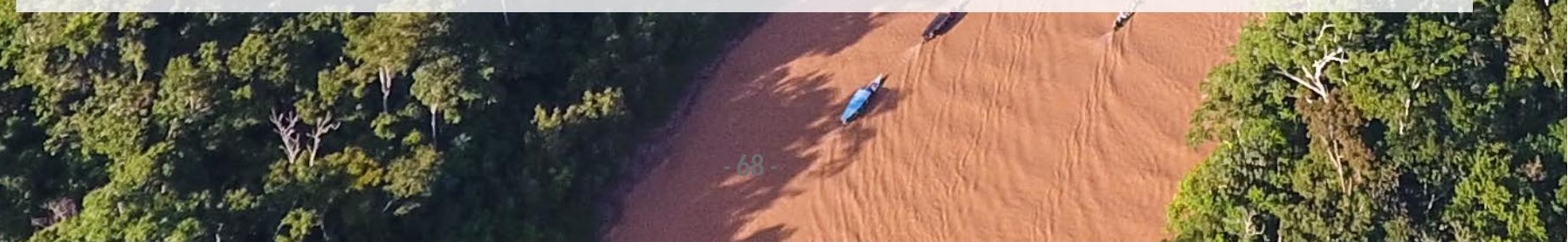


(1)

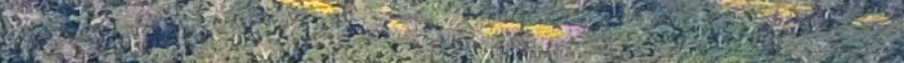

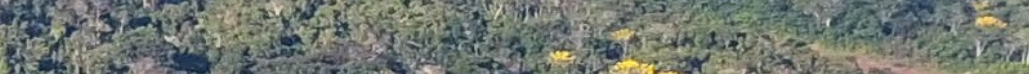

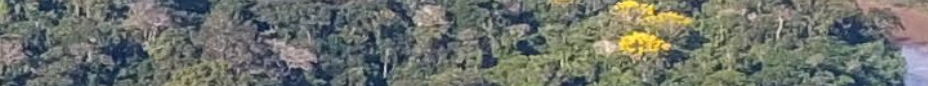

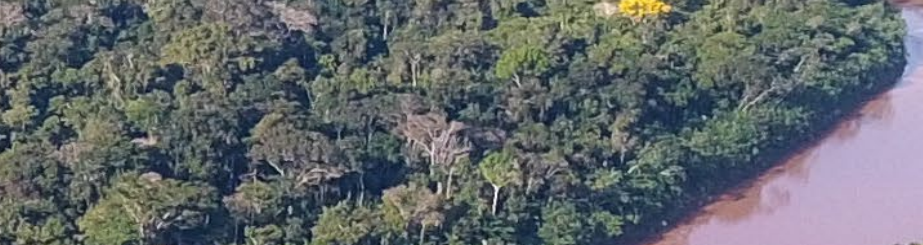

Shis

7 sing

the

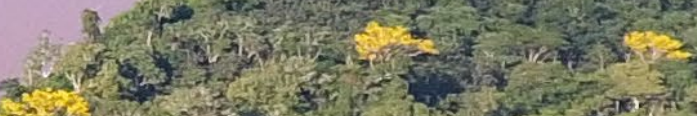

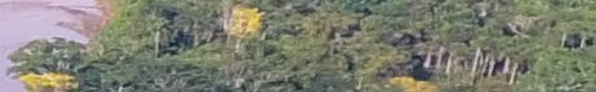

intitis

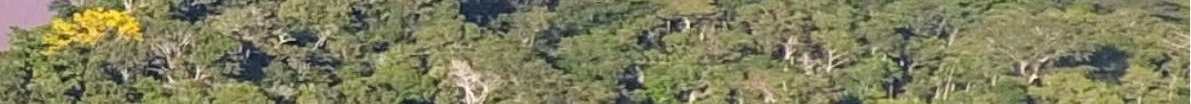

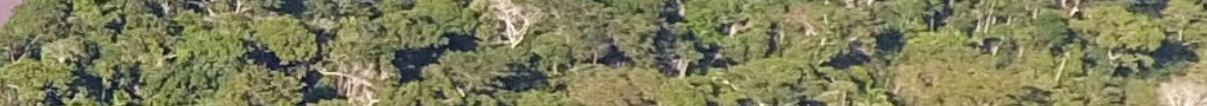

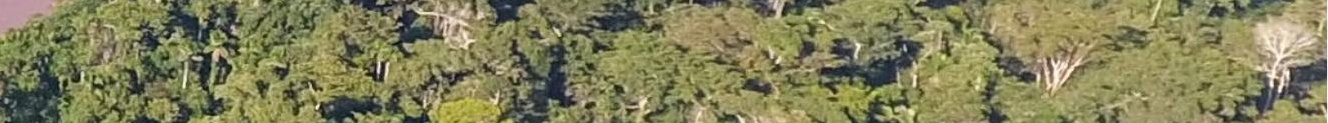

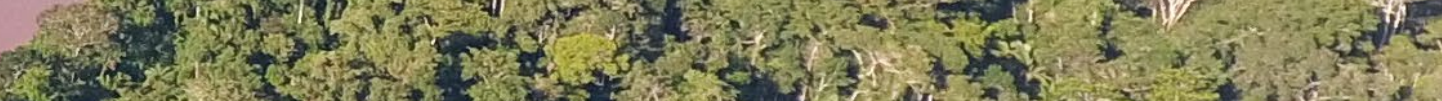

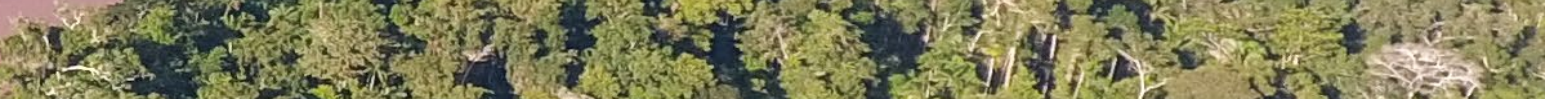
H.

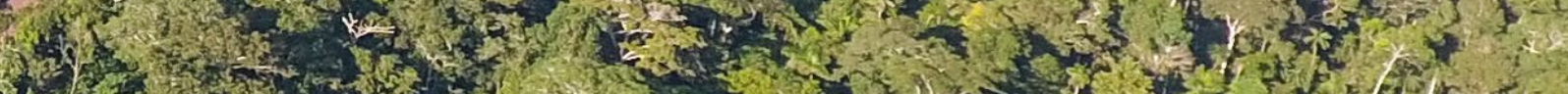
40
4 H.

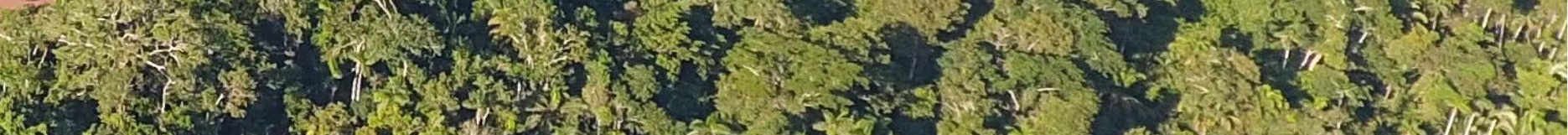

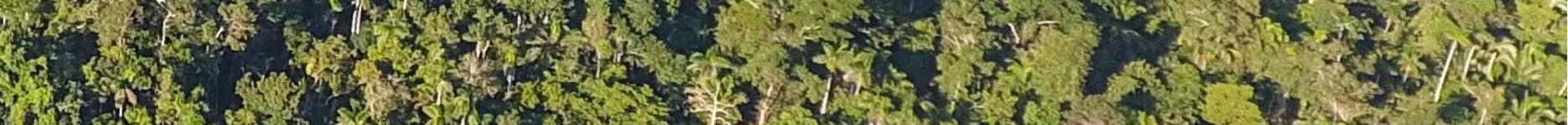

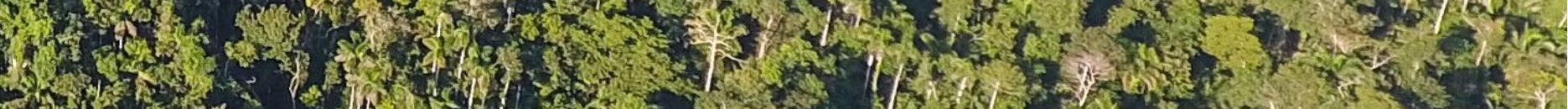

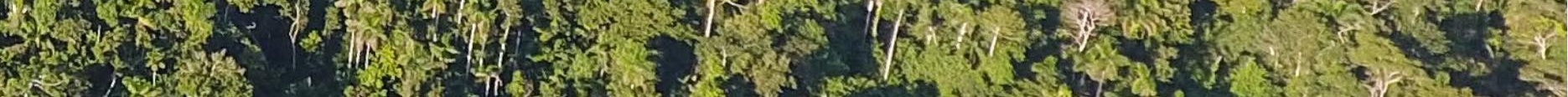

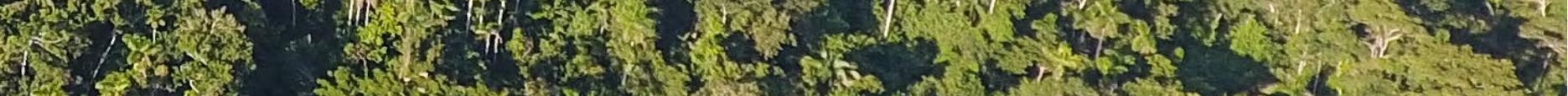
1.

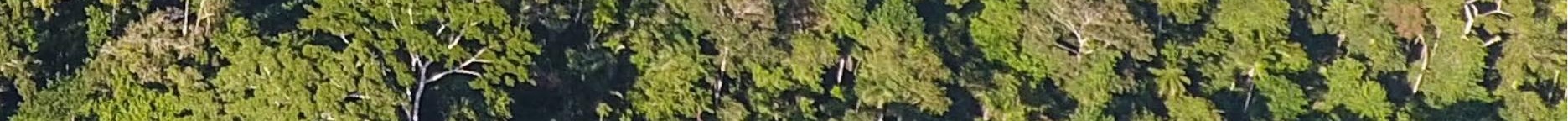

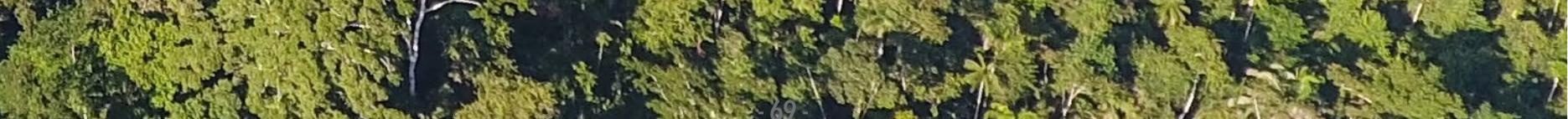

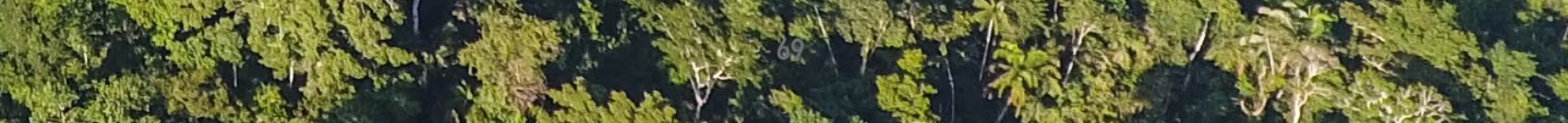




\section{RECOMMENDATIONS FOR FUTURE STUDIES}

Evaluations regarding the effectiveness of Protected Areas and Indigenous Territories in the Amazon, as well as the contribution of the twelve conservation mosaics supported by the Gordon and Betty Moore Foundation, could be improved through the following actions:

- Given that the Amazon basin is the largest freshwater system in the world, it will be important to update our analyses to include fish as the fifth and final vertebrate group. This would provide further weight to these analyses as a unique and complete study of vertebrate diversity in the Amazon and would also allow the incorporation of further spatial lenses, in particular that of watersheds and basins. Given the ongoing advances in GIS and spatial data on Amazonian watersheds by the Amazon Waters Initiative in which WCS and the Gordon and Betty Moore Foundation have both been key players, it would seem logical to take advantage of that synergy and prioritize those studies as soon as possible. The very recent publications of a complete species list for Amazonian watersheds (Dagosta \& De Pinna 2019), and patterns of fish diversity across basins (Oberdorff et al. 2019), would now allow us to adapt our methodologies to include fish in these analyses.

- A second priority would be to update our alpha, beta and gammadiversity analyses for amphibians, reptiles, birds, mammals and the terrestrial vertebrates in general for the entire South America 


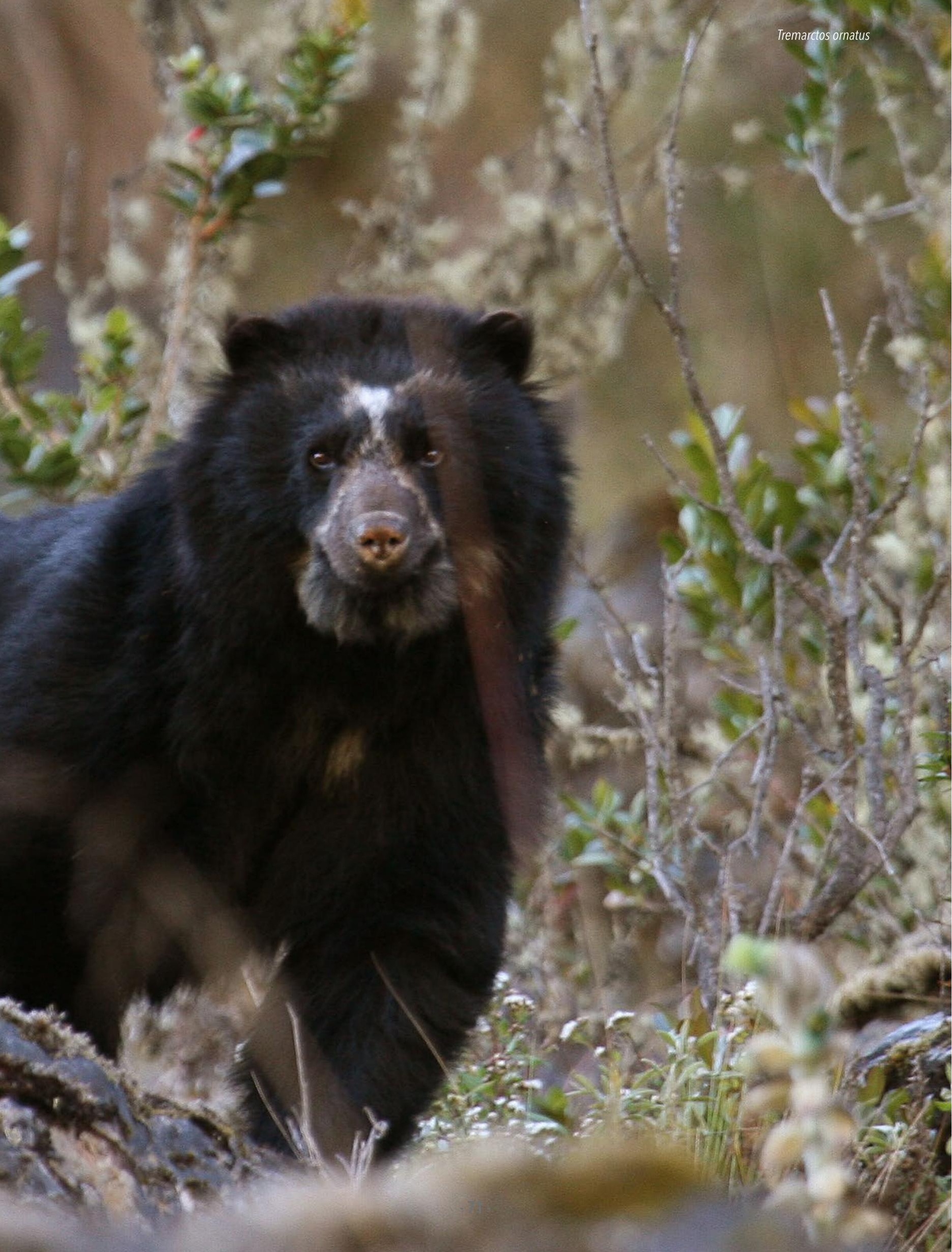


continent which would further highlight our

unique fine-scale analysis, provide geographic

context regarding the importance of the Amazon basin, and identify biodiversity concentrations at the continental scale.

- Thirdly, we recommend an additional analysis concentrating on endemic species richness including representativeness and complementarity.

- A fourth future analysis should concentrate on identifying the most profitable areas for potential new protected area creation in the Amazon basin from the perspective of biodiversity conservation, both in terms of adding species protected within at least one Protected Area or Indigenous Territory, ensuring ecosystem coverage, and guaranteeing adequate local and regional connectivity.

- Fifthly, our database would permit analyses to identify specific variables regarding environmental heterogeneity as predictors of beta-diversity for amphibians, reptiles, birds and mammals at the different analysis scales considered herein. These analyses may help identify the possible impacts of of climate change on populations of these vertebrate species.
- Another pathway to improve future analyses, would be to use confirmed locality information to develop predictive distribution models for species for which current IUCN information and distributions from other sources (Roll et al. 2017) are considered weak, particularly for some amphibian, reptile and mammal species.

- These analyses could also be run for protected areas systems as official units of management, for example, all the government run areas in the Peruvian Amazon, or a regional network of conservation areas in Loreto, or the protected areas of Colombia.

- Finally, apart from the Protected Areas, Indigenous Territories and conservation mosaics supported by the Gordon and Betty Moore Foundation, it would also be interesting to include the biodiversity conservation contribution of other types of conservation unit such as forestry concessions or RAMSAR sites in the Amazon basin. 


\section{$-\cdots$

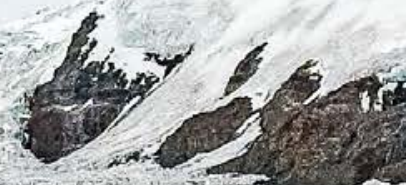

-

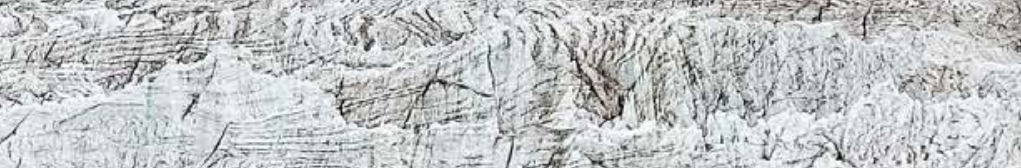

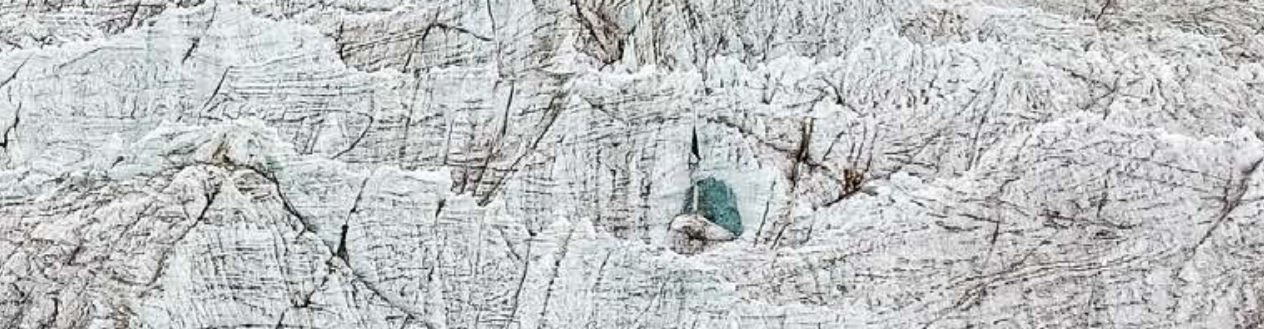

$x+x^{2}-x^{2}$

in $x=2$

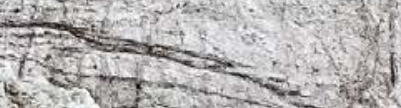

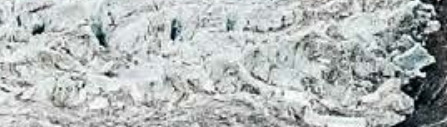

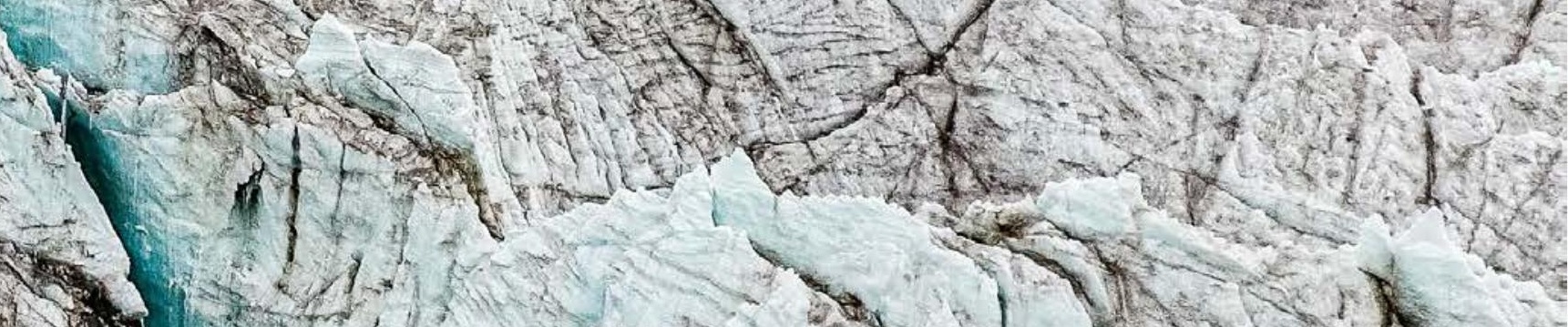

$211 \times 1$

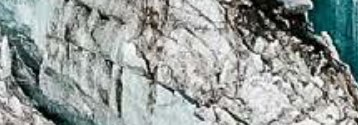

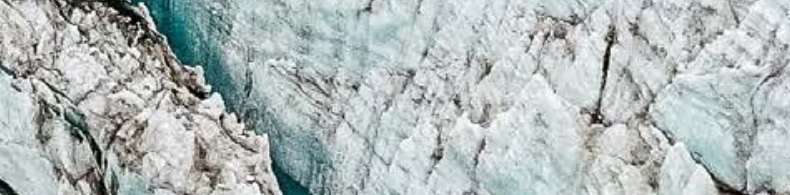

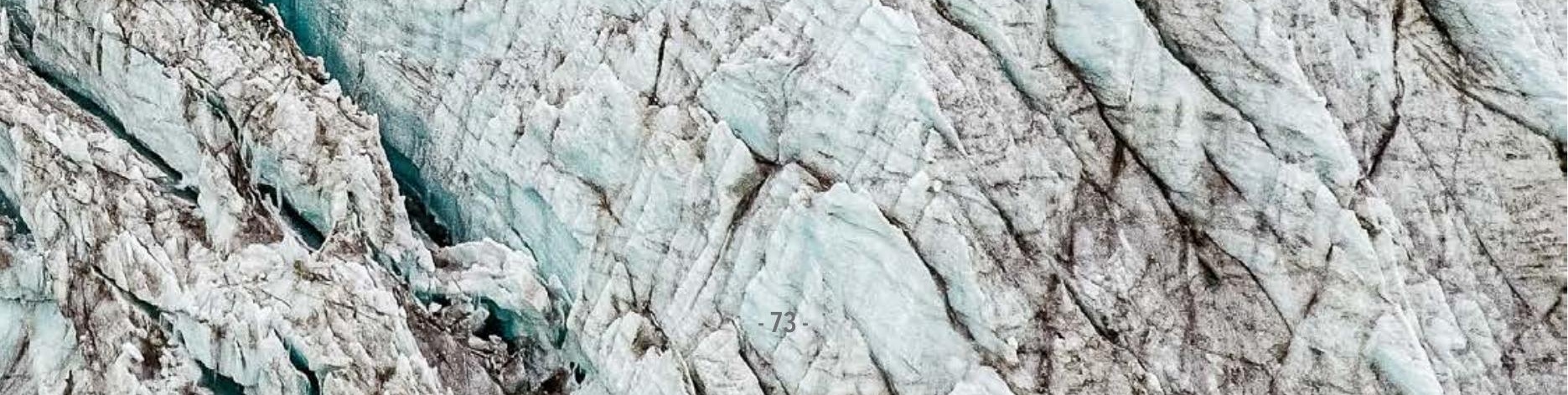




\section{REFERENCES}

- $\quad$ Aguirre LF, Tarifa T, Wallace R, Salazar-Bravo J, Bernal NH, Siles L\& Aliaga-Rossel E. 2019. Lista actualizada y comentada de los mamíferos de Bolivia. Ecología en Bolivia.

- $\quad$ AmphibiaWeb. 2019. <https://amphibiaweb.org> University of California, Berkeley, CA, USA. Accessed 21 March 2019.

- Antonelli A, Quijada-Mascareñas A, Crawford AJ, Bates JM, Velazco PM \& Wuster W. 2010. Molecular studies and phylogeography of Amazonian tetrapods and their relation to geological and climatic models. In: Hoorn C \& Wesselingh FP (Eds.). Amazonia, Landscape and Species Evolution: A Look into the Past (pp. 386-404). Wiley-Blackwell, London, UK.

- Araújo MB. 2002. Biodiversity hotspots and zones of ecological transition. Conservation Biology 16: 1662-1663.

- Azevedo-Júnior SM. 1998. As aves do canal de Santa Cruz, Pernambuco, Brasil. Caderno Ômega da Universidade Federal Rural de Pernambuco, Série Ciências Aquáticas 5: 35-50.

- Barlow J, França F, Gardner TA, et al. 2018. The future of hyperdiverse tropical ecosystems. Nature 559: 517-526.

- Baselga A. 2010. Multiplicative partition of true diversity yields independent alpha and beta components; additive partition does not. Ecology 91: 1974-1981.

- Bass MS, Finer M, Jenkins CN, Kreft H, Cisneros-Heredia DF, et al. 2010. Global conservation significance of Ecuador's Yasuní National Park. PLoS ONE 5: e8767.

- Bates JM. 2001. Avian diversification in Amazonia: evidence for historical complexity and a vicariance model for a basic pattern of diversification. In: Viera I, MA D'Incao, Cardoso da Silva JM \& Oren D (Eds.). Diversidade Biológica e Cultural da Amazônia (pp. 119-138). Museu Paraense Emilio Goeldi, Belém, Pará, Brasil.

- Bélisle M. 2005. Measuring landscape connectivity: the challenge of behavioral landscape ecology. Ecology 86: 19881995.

- BirdLife International \& NatureServe. 2018. Bird Species Distribution Maps of the World. BirdLife International, Cambridge, UK and NatureServe, Arlington, USA.

- Blackman A, Corral L, Santos Lima E \& Asner G. 2017. Titling indigenous communities protects forests in the Peruvian Amazon. Proceedings of the National Academy of Sciences of the United States of America 114: 4123-4128.

- Buckley LB \& Jetz W. 2008. Linking global turnover of species and environments. Proceedings of the National Academy of Sciences of the United States of America 105: 17836-17841.

- Burns KJ \& Naoki K. 2004. Molecular phylogenetics and biogeography of Neotropical tanagers in the genus Tangara. Molecular Phylogenetics \& Evolution 32: 838-854.

- Canale GR, Peres C, Guidorizzi CE, Ferreira-Gato CA \& Kierulff
CM. 2012. Pervasive defaunation of forest remnants in a tropical biodiversity hotspot. Plos One 7: e41671.

- Castro G \& Riega-Campos S. 2014. An Analysis of International Conservation Funding in the Amazon. Washington DC Ecosystem Services. Palo Alto, CA: Gordon and Betty Moore Foundation. http://www.vale.com/brasil/PT/aboutvale/ news/Documents/Amazon-ConservationFunding-AnalysisPublication-2014.pdf 24 pp.

- Ceballos G \& Ehrlich PR. 2006. Global mammal distributions, biodiversity hotspots, and conservation. Proceedings of the National Academy of Sciences of the United States of America 103: 19374-19379.

- Chape S, Harrison J, Spalding M \& Lysenko I. 2005. Measuring the extent and effectiveness of protected areas as an indicator for meeting global biodiversity targets. Philosophical Transactions of the Royal Society of London Series B, Biological Sciences 360: 443-455.

- Colwell RK. 2009. Biodiversity: concepts, patterns, and measurement. In: LevinS(Eds.). The Princeton Guide to Ecology (pp. 257-263). Princeton, NJ: Princeton University Press.

- Conrad O, Bechtel B, Bock M, Dietrich H, Fischer E, Gerlitz L, Wehberg J, Wichmann V \& Böhner J. 2015. System for Automated Geoscientific Analyses (SAGA) v. 2.1.4, Geoscientific Model Development 8: 1991-2007.

- Dagosta FCP \& De Pinna M. 2019. The fishes of the Amazon: Distribution and biogeographical patterns, with a comprehensive list of species. Bulletin of the American Museum of Natural History 431: 1-163.

- Da Silva JMC, Rylands AB \& da Fonseca GAB. 2005. The fate of the Amazonian areas of endemism. Conservation Biology 19: 689-694.

- De Oliveira TG, Mazim FD, Vieiria 0Q, Barnett APA, Do N Silva G, Soares JBG, Santos JP, Da Silva VF, Araujo PA, Tchaika L \& Miranda CL. 2016. Nonvolant mammal megadiversity and conservation issues in a threatened Central Amazonian hotspot in Brazil. Tropical Conservation Science 2016: 1-16.

- Defler T. 2019. History of terrestrial mammals in South America, how South American mammalian fauna changed from the Mesozoic to recent times. Topics in Geobiology 42, Springer Nature Switzerland, AG. 372 pp.

- Dirzo R \& Raven PH. 2003. Global state of biodiversity and loss. Annual Review Environment and Resources 28: 137-167.

- Duellman WE. 1999. Patterns of Distribution of Amphibians: A Global Perspective. John Hopkins University Press, Baltimore, Maryland, USA. 633 pp.

- $\quad$ Finer M, Jenkins CN, Pimm SL, Keane B \& Ross C. 2008. Oil and gas projects in the western Amazon: Threats to wilderness, 
biodiversity, and indigenous peoples. PLOS ONE 3: e2932.

- Foley JA, Asner GP, Costa MH, Coe MT, DeFriest R, Gibbs HK, Howard EA, Olson S, Patz J, Ramankutty N \& Snyder P. 2007. Amazonia revealed: forest degradation and loss of ecosystem goods and services in the Amazon Basin. Frontiers in Ecology and the Environment 5: 25-32.

- Foley JA, DeFries R, Asner GP, Barford C, Bonan G, Carpenter SR, Chapin FS, Coe MT, Daily GC, Gibbs HK, et al. 2005. Global consequences of land use. Science 309: 570-574.

- Frost DR. 2019. Amphibian Species of the World: An Online Reference. Version 6.0 (21 January, 2019). Electronic Database accessible athttp://research.amnh.org/herpetology/amphibia/ index.html. American Museum of Natural History, New York, USA.

- GADM database. 2018. GADM hosted at Center for Spatial Sciences at the University of California, Davis, version 3.4, April 2018.

- Gaston KJ \& Spicer Jl. 2004. Biodiversity: An Introduction. Blackwell, USA. 207 pp.

- GBIF.org (14 August 2018). 2019. GBIF Occurrence Download https://doi.org/10.15468/dl.example-donotcite. Accessed 20 May, 2019.

- Gentry A. 1988. Tree species richness of upper Amazonian forests. Proceedings of the National Academy of Sciences 85: 156-159.

- Gil G \& Moreno CE. 2007. Los análisis de complementariedad aplica-dos a la selección de reservas de la biosfera: efecto de la escala. In: Halffter G, Guevara S \& Melic A (Eds.). Hacia una Cultura de Conservación de la Diversidad Biológica (pp. 63-70). Sociedad Entomológica Aragonesa, Zaragoza, España.

- Gomes VHF, Vieira ICG, Salo Salomão RP \& ter Steege H. 2019. Amazonian tree species threatened by deforestation and climate change. Nature Climate Change 9: 547-553.

- González I, Noguera-Urbano EA, Velásquez-Tibatá J \& OchoaQuintero JM. 2018. Especies endémicas, áreas protegidas y deforestación. In: Moreno LA, Andrade GI \& Gómez MF (Eds.). Biodiversidad 2018, Estado y Tendencias de la Biodiversidad Continental de Colombia (pp. 1-2). Instituto de Investigación de Recursos Biológicos Alexander von Humboldt, Bogotá, D. C., Colombia.

- $\quad$ González-Maya JF, Víquez-R LR, Belant JL \& Ceballos G. 2015. Effectiveness of protected areas for representing species and populations of terrestrial mammals in Costa Rica. PLOS ONE 10: 1-16. e0124480.

- Gray CL, Hill SLL, Newbold T, Hudson LN, Boïrger L, Contu S, Hoskins AJ, Ferrier S, Purvis A \& Scharlemann JPW. 2016. Local biodiversity is higher inside than outside terrestrial protected areas worldwide. Nature Communications 7: 12306 (1-7).

- Gregorius HR, Bergmann F \& Wehenkel C. 2003. Analysis of biodiversity across levels of biological organization: a problem of defining traits. Perspectives in Plant Ecology, Evolution and Systematics 5: 209-218.

- Gullison RE \& Hardner J. 2018. Progress and challenges in consolidating the management of Amazonian protected areas and indigenous territories. Conservation Biology 32: 1020-1030.

- Hoorn C \& Wesselingh FP. 2010. Amazonia, Landscape and Species Evolution: A Look into the Past. Wiley-Blackwell, Chichester, UK. 447 pp.

- Hoorn C, Wesselingh FP, ter Steege H, Bermudez MA, Mora A, Sevink J, Sanmartín I, Sanchez-Meseguer A, Anderson CL, Figueiredo JP, Jaramillo C, Riff D, Negri FR, Hooghiemstra H, Lundberg J, Stadler T, Särkinen T \& Antonelli A. 2010. Amazonia through time: Andean uplift, climate change, landscape evolution, and biodiversity. Science 330: 927-931.

- Horn CM, Vargas-Paredes VH, Gilmore MP \& Endress BA. 2018. Spatio-temporal patterns of Mauritia flexuosa fruit extraction in the Peruvian Amazon: Implications for conservation and sustainability. Applied Geography 97: 98-108.

- $\quad$ Hutter CR, Guayasamin JM \& Wiens JJ. 2013. Explaining Andean megadiversity: the evolutionary and ecological causes of glass frog elevational richness patterns. Ecology Letters 16: $1135-1144$.

- $\quad$ INPE, DEGRAD. 2012. Amazon Forest Degradation Database. Available at: www. obt.inpe.br/degrad

- IUCN 2018. The IUCN Red List of Threatened Species. Version 2016-1. http://www.iucnredlist.org.

- IUCN 2019. The IUCN Red List of Threatened Species. Version 2016-1. http://www.iucnredlist.org.

- ITIS. 2019. Retrieved [March, 1, 2019] from the Integrated Taxonomic Information System on-line database, http://www. itis.gov.

- Jacinto-Flores $\mathrm{NE}$, Sánchez-González LA \& Almazán-Núñez RC. 2017. Patrones de distribución y zonas prioritarias para la conservación de la avifauna de la costa del Pacífico de Guerrero, México. Revista Mexicana de Biodiversidad 88: 960-977.

- Jenkins CN, Pimm SL \& Joppa LN. 2013. Global patterns of terrestrial vertebrate diversity and conservation. Proceedings of the National Academy of Sciences 110: E2602-10.

- Jonas HD, Barbuto V, Jonas HC, Kothari A \& Nelson F. 2014. New steps of change: looking beyond protected areas to consider other effective area-based conservation measures. Parks 20: 111-128.

- Juen L\& De Marco P JR. 2011. Odonate biodiversity in terrafirme forest streamlets in Central Amazonia: on the relative effects of neutral and niche drivers at small geographical extents. Insect Conservation and Diversity 4: 265-274.

- $\quad$ Kati V, Devillers P, Dufrene M, Legakis A, Vokou D \& Lebrun P. 2004. Hotspots, complementarity or representativeness? Designing optimal small-scale reserves for biodiversity 
conservation. Biological Conservation 120: 471-480.

- Kolár F, Dušková E. \& Sklenář P. 2016. Niche shifts and range expansions along cordilleras drove diversification in a highelevation endemic plant genus in the tropical Andes. Molecular Ecology 25: 4593-4610.

- $\quad$ Kröger M \& Lalander R. 2016. Ethno-territorial rights and the resource extraction boom in Latin America: do constitutions matter? Third World Quarterly 37: 682-702.

- Laurance WF, Sayer J \& Gassmam KE. 2014. Agricultural expansion and its impacts on tropical nature. Trends Ecology and Evolution 29: 107-116.

- Latrubesse EM, Arima EY, Dunne T, Park E, BakerVR, d'Horta FM, Wight C, Wittmann F, Zuanon J, Baker PA, Ribas CC, Norgaard RB, Filizola N, Ansar A, Flybjerg B \& Stevaux JC. 2017. Damming the rivers of the Amazon basin. Nature 546: 363-369.

- Lennon JJ, Greenwood JJD \& Turner JRG. 2000. Bird diversity and environmental gradients in Britain: a test of the speciesenergy hypothesis. Journal of Animal Ecology 69: 581-598.

- Lim BK. 2012. Biogeography of mammals from the Guianas of South America. In: Patterson BD \& Costa LP(Eds.). Bones, Clones and Biomes: The History and Geography of Recent Neotropical Mammals (pp. 230-258). University of Chicago Press, Chicago, Illinois, USA.

- Lim BK \& Tavares VC. 2012. Review of species richness and biogeography of bats (Chiroptera) from the Guiana subregion of South America with comments on conservation. Ecotropica 18: 105-118.

- Lim BK. 2018. Review of mammalogical research in the Guianas of northern South America. Integrative Zoology 11: 151-161.

- Lira-Noriega A, Soberón J, Navarro-Siguenza AG, Nakazawa Y \& Peterson AT. 2007. Scale dependency of diversity components estimated from primary biodiversity data and distribution maps: Biodiversity research. Diversity \& Distributions 13: 185 195.

- Lombard A. 1995. The problem with multi-species conservation: do hotspots, ideal reserves and existing reserves coincide? South African Journal of Zoology 30: 145-163.

- Lovejoy TE \& Nobre C. 2018. Amazon tipping point. Science Advances 4. DOI: 10.1126/sciadv.aat2340

- MacArthur RH. 1972. Geographical Ecology: Patterns in the Distribution of Species. New York: Harper \& Row. 288 pp.

- Malhi Y, Roberts JT, Betts RA, Killeen TJ, Li W \& Nobre CA. 2008. Climate change, deforestation, and the fate of the Amazon Yadvinder. Science 319: 169-.172

- Mammal Diversity Database. 2019. www.mammaldiversity.org. American Society of Mammalogists. Accessed 10 March, 2019.

- MacNally R, Fleishman E, Bulluck LP \& Betrus CJ. 2004. Comparative influence of spatial scale on beta diversity within regional assemblages of birds and butterflies. Journal of Biogeography 31: 917-929.

- Maxwell SL, Fuller RA, Brooks TM \& Watson JEM. 2016.
Biodiversity: the ravages of guns, nets and bulldozers. Nature 536, 143-145.

- $\quad$ Melo AS, Rangel TF \& Diniz-Filho JAF. 2009. Environmental drivers of beta-diversity patterns in New-World birds and mammals. Ecography 32: 226-236.

- Metzger JP, Bustamanteb MMC, Ferreira J, Fernandes WG, Librán-Embide F, Pillar VD, Prista PR, Rodrigues RR, Vieira ICG \& Overbecki GE. 2019. Why Brazil needs its legal reserves. Perspectives in Ecology and Conservation. D0I.org/10.1016/j. pecon.2019.07.002

- $\quad$ Minteer CR, Smith MC, Lake LC \& Pokorny E. 2018. Teaching complex ecological concepts through a demonstration garden: biodiversity, invasive species, and conservation in practice. The American Biology Teacher 80: 346-352.

- Moreno CE. 2001. Métodos para medir la biodiversidad. M\&TManuales y Tesis SEA, vol.1.Zaragoza, España. 84 pp.

- Moreno CE, Barragán F, Pineda E \& Pavón NP. 2011. Reanalyzing alpha diversity: alternatives to understand and compare information about ecological communities. Revista Mexicana de Biodiversidad 82: 1249-1261.

- Myers N, Mittermeier RA, Mittermeier CG, da Fonseca GAB \& Kent J. 2000. Biodiversity hotspots for conservation priorities. Nature 403: 853-858.

- Nepstad D, Schwartzman S, Bamberger B, Santilli M, Ray D, Schlesinger P, Lefebvre P, Alencar A, Prinz E, FiskE G \& Rolla A. 2006. Inhibition of Amazon Deforestation and Fire by Parks and Indigenous Lands. Conservation Biology 1: 65-73.

- OberdorffT, Dias MS, Jézéquel C, Albert JS, Arantes CC, Bigorne R, Carvajal-Valleros FM, De Wever A, Frederico RG, Hidalgo M, Hugueny B, Leprieur F, Maldonado M, Maldonado-0campo J, Martens K, Ortega H, Sarmiento J, Tedesco PA, Torrente-Vilara G, Winemiller KO \& Zuanon J. 2019. Unexpected fish diversity gradients in the Amazon basin. Science Advances 5, eaav8681.

- Ochoa-Ochoa LM, Munguía M, Lira-Noriega A, Sánchez-Cordero V, Flores-Villela O, Navarro-Siguenza A, et al. 2014. Spatial scale and $\beta$-diversity of terrestrial vertebrates in Mexico. Revista Mexicana de Biodiversidad 85: 918-930.

- Oliveira U, Soares-Filho BS, Paglia AP, Brescovit AD, Carvalho CJB, Silva DP, Rezende DT, Leite SFS, Batista JAN, Barbosa JPPP, Stehman JR, Ascher JS, Vasconcelos MS, De Marco P, Löwenberg-Neto P, Ferro VG \& Santos AJ. 2017. Biodiversity conservation gaps in the Brazilian protected areas. Scientific Reports 7: 9141.

- Olson DM, Dinerstein E, Canevari P, Davidson I, Castro GV, et al. 1998. Freshwater Biodiversity of Latin America and the Caribbean: A Conservation Assessment. Biodiversity Support Program, Washington, DC. 61 pp.

- $\quad$ Paglia AP, Fonseca GAB da, Rylands AB, Herrmann G, Aguiar LMS, Chiarello AG, Leite YLR, Costa LP, Siciliano S, Kierulff MCM, Mendes SL, Tavares VdaC, Mittermeier RA \& Patton JL. 2012. Lista anotada dos mamíferos do Brasil / Annotated checklist of 
Brazilian mammals, $2^{a}$ Edição / 2nd Edition. Occasional Papers in Conservation Biology 6: 1-76.

- Patton JL, Pardiñas UFJ \& D'Elía G. 2015. Mammals of South America, Volume 2: Rodents. University of Chicago Press, USA. 1,384 pp.

- Peres C. 1990. Effects of hunting on western Amazonian primate communities. Biological Conservation 54: 47-59.

- Peres C. 2007. Basin-wide effects of game harvest on vertebrate population densities in Amazonian forests: implications for animal-mediated seed dispersal. Biotropica 39: 304-315.

- Pitman NCA, Terborgh J, Silman MR, Nunez P, Neill DA, Ceron CE, Palacios WA \& Aulestia M. 2002. A comparison of tree species diversity in two upper Amazonian forests. Ecology 83: 3210-3224.

- Pressey RL, Possingham HP \& Day JR. 1997. Effectiveness of alternative heuristic algorithms for identifying indicative minimum requirements for conservation reserves. Biological Conservation 80: 207-219.

- Pringle RM. 2017. Upgrading protected areas to conserve wild biodiversity. Nature 546: 91-99.

- Programa de las Naciones Unidas para el Medio Ambiente (PNUMA). 2010. Perspectivas del Medio Ambiente: América Latina y el Caribe. GEO ALC 3.80 pp.

- Prüssmann J, Suárez CF \& Chaves ME. 2017. Atlas of Conservation Opportunities in the Amazon Biome under Climate Change Considerations. WWF, Redparques, FAO, UICN Y PNUMA, Cali, Colombia. 80 pp.

- Purvis A, Newbold T, De Palma A, Contu S, Hill SLL, SanchezOrtiz K, et al. 2018. Modelling and projecting the response of local terrestrial biodiversity worldwide to land use and related pressures: the PREDICTS project. Advances Ecology in Research 58: 201-241.

- $\quad$ QGIS Development Team. 2018. QGIS Geographic Information System. Open Source Geospatial Foundation Project. https:// qgis.org.

- Qian H. 2009. Global comparisons of beta diversity among mammals, birds, reptiles, and amphibians across spatial scales and taxonomic ranks. Journal of Systematics and Evolution 47: 509-514.

- Quan Q, Che X, Wu Y, Wu Y, Zhang O, Zhang M \& Zou F. 2017. Effectiveness of protected areas for vertebrates based on taxonomic and phylogenetic diversity. Conservation Biology 32: $355-365$.

- Rahbek C \& Graves GR. 2001. Multiscale assessment of patterns of avian species richness. Proceedings of the National Academy of Sciences 98: 4534-4539.

- RAISG (Red Amazónica de Información Socioambiental Georreferenciada) 2016. Cartografía Histórica de Áreas Naturales Protegidas y Territorios Indígenas en la Amazonía. Version digital. $161 \mathrm{pp}$.

- RAISG (Red Amazónica de Información Socioambiental
Georreferenciada) 2017. Mapa de Áreas Naturales Protegidas y Territorios Indígenas en la Amazonía. Versión digital. https:// www.amazoniasocioambiental.org/es/mapas/

- RAISG (Red Amazónica de Información Socioambiental Georreferenciada) 2019. Mapa 2019 de Áreas Naturales Protegidas y Territorios Indígenas en la Amazonía. Versión digital. https://www.amazoniasocioambiental.org/es/mapas/

- RAISG (Red Amazónica de Información Socioambiental Georreferenciada) 2019. Datos Cartográficos de Límites de Áreas Naturales Protegidas y Territorios Indígenas de la Amazonia. Formato shapefile. https://www.amazoniasocioambiental.org/ es/mapas/

- Ramírez-Chaves HE, Suárez-Castro AF \& González-Maya JF. 2016. Cambios recientes a la lista de los mamíferos de Colombia. Mammalogy Notes|Notas Mastozoológicas Sociedad Colombiana de Mastozoología 3: 1-20.

- ReDPARQUeS 2018. Avances en la Implementación del Programa de Trabajo sobre Áreas Protegidas 2016-2017: Región Bioma Amazónico. Proyecto IAPA - Visión Amazónica. REDPARQUES, WWF, FAO, UICN, ONU Medio Ambiente. Bogotá, Colombia. $36 \mathrm{pp}$.

- $\quad$ Remsen JV Jr, Areta JI, Cadena CD, Claramunt S, Jaramillo A, Pacheco JF, Robbins MB, Stiles FG, Stotz DF \& Zimmer KJ. Version [20-12-2018]. 2018. A Classification of the Bird Species of South America. American Ornithologists' Union. http://www. museum.Isu.edu/ Remsen/SACCBaseline.htm.

- RENFORESAP 2018. Fortalecimiento de la Red de Áreas Protegidas del Escudo Guayanés y sus Contribuciones al Desarrollo Sostenible en Relación a las Culturas, Valores y Modos de Vida Locales. Proyecto 2018-2020, Guyana, Suriname \& Guyana Francesa.

- Reyers B, van Jaarsveld AS \& Krüger M. 2000. Complementarity as a biodiversity indicator Strategy. Proceedings of the Royal Society Part B: Biological Sciences 267: 505-513.

- $\quad$ Riff D, Romano PSR, Oliveira GR \& Aguilera OA. 2010. Neogene crocodile and turtle fauna in northern South America. In: Hoorn C \& Wesselingh FP (Eds.). Amazonia, Landscape and Species Evolution: A Look into the Past (pp. 259-280). Wiley-Blackwell, London, UK.

- Rodríguez P, Ochoa-Ochoa LM, Munguía M, Sánchez-Cordero V, Navarro-Siguenza AG, Flores-Villela OA \& Nakamura M. 2019. Environmental heterogeneity explains coarse-scale $\beta$-diversity of terrestrial vertebrates in Mexico. PLOS ONE 14: e0210890.

- Roll U, Feldman A, Novosolov M, Allison A, Bauer A, Bernard R, et al. 2017. The global distribution of tetrapods reveals a need for targeted reptile conservation. Nature, Ecology \& Evolution 1: 1677-1682.

- Ron SR, Merino-Viteri A \& Ortiz DA. 2019. Fauna del Ecuador. Version 2019.0. Museo de Zoología, Pontificia Universidad Católica del Ecuador. <https://bioweb.bio/faunaweb/ amphibiaweb>, fecha de acceso 3 de enero, 2019. 
- $\quad$ Rowe R \& Myers M. 2019. All the World's Primates, www. alltheworldsprimates.org. Primate Conservation Inc., Charlestown Rl. Accessed 21 April, 2019.

- Sala OE, Stuart Chapin F, Armesto III JJ, Berlow E, Bloomfield J, Dirzo R, Huber-Sanwald E, Huenneke LF, Jackson RB, Kinzig A, Leemans R, Lodge DM, Mooney HA, Oesterheld M, Poff NLet al. 2000. Global biodiversity scenarios for the year 2100 . Science 287: 1770-1774.

- Sánchez JH \& Daniel L. 2012. Lista actualizada y comentada de los mamíferos de Venezuela. Memoria de la Fundación La Salle de Ciencias Naturales 2012 ("2010") 1: 173-238.

- Santos JC, Coloma LA, Summers K, Caldwell JP, Ree R \& Cannatella DC. 2009. Amazonian amphibian diversity is primarily derived from Late Miocene Andean lineages. PLoS Biol 7: e1000056.

- Schleicher J, Peres CA, Amano T, Llactayo W \& Leader-Williams N. 2017. Conservation performance of different conservation governance regimes in the Peruvian Amazon. Nature Scientific Reports 7: 11318(1-10).

- Schleicher J, Peres CA \& Leader-Williams N. 2019. Conservation performance of tropical protected areas: How important is management? Conservation Letters: e12650.

- Schulman L, Ruokolainen K, Junikka L, Sääksjärvi IE, Salo M, Juvonen SK, Salo J \& Higgins M. 2007. Amazonian biodiversity and protected areas: do they meet? Biodiversity and Conservation 16: 3011-3051.

- $\quad$ Schuster R, Germain RR, Bennett JR, Reo NJ \& Arcese P. 2019. Vertebrate biodiversity on indigenous-managed lands in Australia, Brazil, and Canada equals that in protected areas. Environmental Science and Policy 101: 1-6.

- Schwartzman S, Moreira AG \& Nepstad DC. 2000. Rethinking tropical forest conservation: perils in parks. Conservation Biology 14: 1351-1357.

- Sloan S, Jenkins CN, Joppa LN, Gaveau DLA \& Laurence WF. 2014. Remaining natural vegetation in the global biodiversity hotspots. Biological Conservation 177: 12-24.

- Soares-Filho BS, Nepstad DC, Curran LM, Cerqueira GC, Garcia RA, Ramos CA, Voll E, McDonald A, Lefebvre P \& Schlesinger P. 2006. Modelling conservation in the Amazon Basin. Nature 440: 520-523.

- Sobral M, Silvius KM, Overman H, Oliveira LFB, Raab TK \& Fragoso JMV. 2017. Mammal diversity influences the carbon cycle through trophic interactions in the Amazon. Nature, Ecology \& Evolution 1: 1670-1676.

- Socolar JB, Gilroy JJ, Kunin WE \& Edwards DP. 2015. How should beta-diversity inform biodiversity conservation? Trends in Ecology \& Evolution 31: 67-80.

- $\quad$ Strelneck D \& Vilela T. 2017. International Conservation Funding in the Amazon: An Updated Analysis. Technical Report, Gordon and Betty Moore Foundation, Palo Alto, California, USA.
- $\quad$ Teta P, Abba AM, Cassini GH, Flores DA, Galliari CA, Lucero SO \& Ramírez M. 2018. Lista revisada de los mamíferos de Argentina. Mastozoología Neotropical, Mendoza, Versión on-line 1: 1-37.

- Tilman D, Balzer C, Hill J \& Befort BL. 2011. Global food demand and the sustainable intensification of agriculture. Proceedings of the National Academy of Sciences of the United States of America 108: 20260-20264.

- Tirira DG. 2018. Mamíferos del Ecuador: Lista Actualizada de Especies - Mammals of Ecuador: Updated Species Checklist (versión 2018.1)- http://mamiferosdelecuador.com

- Tognelli MF \& Kelt DA. 2004. Analysis of determinants of mammalian species richness in South America using spatial autoregressive models. Ecography 27: 427-436.

- Trefaut MR. 2005. The conservation of Brazilian reptiles: Challenges for a megadiverse country. Conservation Biology 19: 659-664.

- Uetz P, Freed P \& Hošek J. 2019. The Reptile Database, http:// www.reptile-database.org. Accessed 15 Feb, 2019.

- Valencia R, Balslev H, Paz G \& Miño C. 1994. High tree alphadiversity in Amazonian Ecuador. Biodiversity and Conservation 3: 21-28.

- Venticinque E, Forsberg B, Barthem RB, Petry P, Hass L, et al. 2016. An explicit GIS-based river basin framework for aquatic ecosystem conservation in the Amazon. Earth System Science Data 8: 651-661/ SNAPP Western Amazon Group - Amazon Aquatic Ecosystem Spatial Framework.

- Venticinque E, Forsberg B, Barthem RB, Petry P, Hass L, et al. 2018. SNAPP Western Amazon Group-Amazon Aquatic Ecosystem Spatial Framework. Knowledge Network for Biocomplexity. doi:10.5063/F1BG2KX8.

- Vieria RRS, Ribeiro BR, Resende FM, Brum FT, Machado N, Sales LP, Macedo L, Soares-Filho B \& Loyola R. 2018. Compliance to Brazil's forest code will not protect biodiversity and ecosystem services. Diversity Distribution 24: 434-438.

- Voss R \& Emmons L. 1996. Mammalian diversity in Neotropical lowland rainforests: a preliminary assessment. Bulletin of the American Museum of Natural History 230: 1-115.

- Walker W, Baccini A, Schwartzman S, Ríos S, Oliveira-Miranda MA, Augusto C, Romero Ruiz M, Soria Arrasco C, Ricardo B, Smith R, Meyer C, Jintiach JC \& Vasquez Campos E. 2014. Forest carbon in Amazonia: the unrecognized contribution of indigenous territories and protected natural areas. Carbon Management 5: 479-485.

- Wallace, R, Torrico, O, Porcel, Z \& Domic E. 2020. Terrestrial Vertebrate Biodiversity in Twelve Andes-Amazon Conservation Units. Wildlife Conservation Society (WCS). La Paz, Bolivia.

- Whittaker RH. Vegetation of the Siskiyou Mountains, Oregon and California. Ecol Monogr. 1960; 30:279-338.

- Wolters V, Bengtsson J \& Zaitsev AS. 2006. Relationship among the species richness of different taxa. Ecology 87: 1886-1895. 
- Young BE, Stuart SN, Chanson JS, Cox NA \& Boucher TM. 2004. Disappearing Jewels: The Status of New World Amphibians. NatureServe, Arlington VA. 53 pp.

- Zimmerman B, Peres CA, Malcolm JR \& Turner T. 2001. Conservation and development alliances with the Kayapó of south-eastern Amazonia, a tropical forest indigenous people. Environmental Conservation 28: 10-22. 



\section{Appendix}

Indigenous Territories and protected areas in the conservation mosaics supported by the Gordon and Betty Moore Foundation. Category: IL= Indigenous Land; $\mathrm{SP}=$ Strict Protection; $\mathrm{SU}=$ Sustainable Use

\begin{tabular}{|c|c|c|c|c|c|}
\hline Conservation unit Name & Type & Category & Mosaic & Country & Hectares \\
\hline Ampiyacu Native Communities & Indigenous Land & IL & Ampiyacu & Peru & 367.459 \\
\hline Ampiyacu-Apayacu & State Park & SU & Ampiyacu & Peru & 435.465 \\
\hline Bajo Putumayo & State Park & SU & Ampiyacu & Peru & 370.606 \\
\hline Maijuna Kichwa & State Park & SU & Ampiyacu & Peru & 392.272 \\
\hline Medio Putumayo & State Park & SU & Ampiyacu & Peru & 370.606 \\
\hline Yaguas & National Park & SP & Ampiyacu & Peru & 872.136 \\
\hline Nhamunda Mapuera & Indigenous Land & IL & Calha Norte & Brazil & 1.050 .000 \\
\hline Paru d'Este & Indigenous Land & IL & Calha Norte & Brazil & 1.535 .500 \\
\hline Trombetas Mapuera & Indigenous Land & IL & Calha Norte & Brazil & 3.971 .000 \\
\hline Tumucumaque & Indigenous Land & IL & Calha Norte & Brazil & 1.535 .500 \\
\hline TI Kaxuyana-Tunayana & Indigenous Land & IL & Calha Norte & Brazil & \\
\hline Faro & State Forest & SU & Calha Norte & Brazil & 635.936 \\
\hline Grao Para & Ecological Station & $\mathrm{SP}$ & Calha Norte & Brazil & 4.245 .819 \\
\hline Jari & Ecological Station & $\mathrm{SP}$ & Calha Norte & Brazil & 227.126 \\
\hline Maicuru & Biological Reserve & $S P$ & Calha Norte & Brazil & 1.173.217 \\
\hline Paru & State Forest & SU & Calha Norte & Brazil & 3.612 .914 \\
\hline Trombetas & State Forest & SU & Calha Norte & Brazil & 3.172 .978 \\
\hline Aguas Negras & Indigenous Land & IL & Chiribiquete-Caqueta & Colombia & 17.818 \\
\hline Anduche de Andoque & Indigenous Land & IL & Chiribiquete-Caqueta & Colombia & 60.350 \\
\hline Chiribiquete & National Park & $\mathrm{SP}$ & Chiribiquete-Caqueta & Colombia & 2.792 .233 \\
\hline Coropoya & Indigenous Land & IL & Chiribiquete-Caqueta & Colombia & 3.878 \\
\hline El Quince & Indigenous Land & IL & Chiribiquete-Caqueta & Colombia & 1.278 \\
\hline El Triunfo & Indigenous Land & IL & Chiribiquete-Caqueta & Colombia & 194 \\
\hline Guayabal & Indigenous Land & IL & Chiribiquete-Caqueta & Colombia & 610 \\
\hline Huitora & Indigenous Land & IL & Chiribiquete-Caqueta & Colombia & 64.890 \\
\hline Jerico-Consaya & Indigenous Land & IL & Chiribiquete-Caqueta & Colombia & 8.364 \\
\hline La Teofila & Indigenous Land & IL & Chiribiquete-Caqueta & Colombia & 1.684 \\
\hline Llanos del Yari & Indigenous Land & IL & Chiribiquete-Caqueta & Colombia & 199.867 \\
\hline Mesai & Indigenous Land & IL & Chiribiquete-Caqueta & Colombia & 7.114 \\
\hline Miriti Parana & Indigenous Land & IL & Chiribiquete-Caqueta & Colombia & 1.549 .277 \\
\hline Monochoa & Indigenous Land & IL & Chiribiquete-Caqueta & Colombia & 265.375 \\
\hline Niñeras & Indigenous Land & IL & Chiribiquete-Caqueta & Colombia & 2.496 \\
\hline Nonuya de Villazul & Indigenous Land & IL & Chiribiquete-Caqueta & Colombia & 265.976 \\
\hline Paez del Libano & Indigenous Land & IL & Chiribiquete-Caqueta & Colombia & 442 \\
\hline Porvenir-Kananguchal & Indigenous Land & IL & Chiribiquete-Caqueta & Colombia & 530 \\
\hline $\begin{array}{c}\text { Puerto Naranjo - Peñas Rojas - Cuerazo El } \\
\text { Diamante }\end{array}$ & Indigenous Land & IL & Chiribiquete-Caqueta & Colombia & 2.914 \\
\hline Puerto Sabalo y Los Monos & Indigenous Land & IL & Chiribiquete-Caqueta & Colombia & 216.291 \\
\hline San Miguel & Indigenous Land & IL & Chiribiquete-Caqueta & Colombia & 173 \\
\hline Yaigoje-Apaporis & National Park & SP & Chiribiquete-Caqueta & Colombia & 1.060 .082 \\
\hline
\end{tabular}




\begin{tabular}{|c|c|c|c|c|c|}
\hline Conservation unit Name & Type & Category & Mosaic & Country & Hectares \\
\hline Igarape Lourdes & Indigenous Land & IL & Itenez-Rondonia & Brazil & 186.000 \\
\hline Pacaas Novos (TI) & Indigenous Land & IL & Itenez-Rondonia & Brazil & 280.000 \\
\hline Rio Guapore & Indigenous Land & IL & Itenez-Rondonia & Brazil & 116.000 \\
\hline Roosevelt & Indigenous Land & IL & Itenez-Rondonia & Brazil & 230.826 \\
\hline Sete de Setembro & Indigenous Land & IL & Itenez-Rondonia & Brazil & 297.870 \\
\hline Uru-Eu-Wau-Wau & Indigenous Land & IL & Itenez-Rondonia & Brazil & 1.867 .120 \\
\hline Zoro & Indigenous Land & IL & Itenez-Rondonia & Brazil & 355.789 \\
\hline Guajara-Mirim & State Park & SP & Itenez-Rondonia & Brazil & 216.568 \\
\hline Itenez & State Forest & SU & Itenez-Rondonia & Bolivia & 1.389 .025 \\
\hline Pacaas Novos & National Park & SP & Itenez-Rondonia & Brazil & 769.801 \\
\hline Rio Cautario & Extractive Reserve & SU & Itenez-Rondonia & Brazil & 220.218 \\
\hline Amana & Sustainable Development Reserve & SU & Lower Rio Negro & Brazil & 2.313 .000 \\
\hline Anavilhanas & National Park & SP & Lower Rio Negro & Brazil & 350.018 \\
\hline Jau & National Park & SP & Lower Rio Negro & Brazil & 2.272 .270 \\
\hline Poranga-Conquista & Sustainable Development Reserve & SU & Lower Rio Negro & Brazil & 76.936 \\
\hline Rio Negro & Sustainable Development Reserve & SU & Lower Rio Negro & Brazil & 103.086 \\
\hline Rio Negro Setor Norte & State Park & SP & Lower Rio Negro & Brazil & 257.422 \\
\hline Rio Negro Setor Sul & State Park & SP & Lower Rio Negro & Brazil & 86.601 \\
\hline Unini & Extractive Reserve & SU & Lower Rio Negro & Brazil & 833.352 \\
\hline Balata-Tufari & National Forest & SU & Madeira & Brazil & 802.023 \\
\hline Canutama & State Forest & SU & Madeira & Brazil & 150.589 \\
\hline Canutama (Resex) & Extractive Reserve & SU & Madeira & Brazil & 197.986 \\
\hline Humaita & National Forest & SU & Madeira & Brazil & 468.790 \\
\hline IgapoAcu & Sustainable Development Reserve & SU & Madeira & Brazil & 394.622 \\
\hline Ituxi & Extractive Reserve & SU & Madeira & Brazil & 776.940 \\
\hline Juma & Sustainable Development Reserve & SU & Madeira & Brazil & 589.611 \\
\hline Agua Preta/Inari & Indigenous Land & IL & Madeira & Brazil & 139.763 \\
\hline Caititu & Indigenous Land & IL & Madeira & Brazil & 308.062 \\
\hline Camicua & Indigenous Land & IL & Madeira & Brazil & 58.159 \\
\hline Diahui & Indigenous Land & IL & Madeira & Brazil & 47.354 \\
\hline Ipixuna & Indigenous Land & IL & Madeira & Brazil & 215.362 \\
\hline Nove de Janeiro & Indigenous Land & IL & Madeira & Brazil & 229.000 \\
\hline Seruini/Mariene & Indigenous Land & IL & Madeira & Brazil & 144.971 \\
\hline Tenharim do Igarape Preto & Indigenous Land & IL & Madeira & Brazil & 87.413 \\
\hline Tenharim Marmelos & Indigenous Land & IL & Madeira & Brazil & 497.521 \\
\hline Matupiri & State Park & $\mathrm{SP}$ & Madeira & Brazil & 513.747 \\
\hline Matupiri (RDS) & Sustainable Development Reserve & SU & Madeira & Brazil & 179.083 \\
\hline Medio Purus & Extractive Reserve & SU & Madeira & Brazil & 604.290 \\
\hline Piagacu Purus & Sustainable Development Reserve & SU & Madeira & Brazil & 1.008 .167 \\
\hline Rio Amapa & Sustainable Development Reserve & SU & Madeira & Brazil & 216.109 \\
\hline Rio Madeira & Sustainable Development Reserve & SU & Madeira & Brazil & 283.117 \\
\hline Tapaua & State Forest & SU & Madeira & Brazil & 881.704 \\
\hline
\end{tabular}




\begin{tabular}{|c|c|c|c|c|c|}
\hline Conservation unit Name & Type & Category & Mosaic & Country & Hectares \\
\hline Bahuaja Sonene & National Park & SP & Madidi-Tambopata & Peru & 1.095 .910 \\
\hline Leco Apolo & Indigenous Land & IL & Madidi-Tambopata & Bolivia & 60.145 \\
\hline LosAmigos & Private Conservation Area & SU & Madidi-Tambopata & Peru & 145.686 \\
\hline Madidi & National Park & SP & Madidi-Tambopata & Bolivia & 1.266 .333 \\
\hline Manuripi & State Park & SU & Madidi-Tambopata & Bolivia & 743.171 \\
\hline Pilon Lajas & Indigenous Land & IL & Madidi-Tambopata & Bolivia & 353.996 \\
\hline Tacanal & Indigenous Land & IL & Madidi-Tambopata & Bolivia & 386.595 \\
\hline Tambopata & National Reserve & SU & Madidi-Tambopata & Peru & 278.873 \\
\hline Alto Purus & National Park & SP & Upper Purus & Peru & 2.501 .793 \\
\hline Cazumba Iracema & Extractive Reserve & SU & Upper Purus & Brazil & 730.794 \\
\hline Chico Mendes & Extractive Reserve & SU & Upper Purus & Brazil & 970.570 \\
\hline Macaua & National Forest & SU & Upper Purus & Brazil & 176.348 \\
\hline Manu & National Park & SP & Upper Purus & Peru & 1.701 .033 \\
\hline Madre de Dios & Indigenous Land & IL & Upper Purus & Peru & 871.092 \\
\hline Mashco Piro & Indigenous Land & IL & Upper Purus & Peru & 2.929 \\
\hline Murunahua & Indigenous Land & IL & Upper Purus & Peru & 475.850 \\
\hline San Francisco & National Forest & SU & Upper Purus & Brazil & 21.147 \\
\hline Alto Rio Negro & Indigenous Land & IL & Upper Rio Negro & Brazil & 7.999 .000 \\
\hline Medio Rio Negro I & Indigenous Land & IL & Upper Rio Negro & Brazil & 1.776 .140 \\
\hline Medio Rio Negro II & Indigenous Land & IL & Upper Rio Negro & Brazil & 316.194 \\
\hline Kichwa & Indigenous Land & IL & Yasuni-Pastaza & Ecuador & 108.000 \\
\hline Sapara & Indigenous Land & IL & Yasuni-Pastaza & Ecuador & 423.303 \\
\hline Tagaere Taromenani & Indigenous Land & IL & Yasuni-Pastaza & Ecuador & 700.000 \\
\hline Waorani & Indigenous Land & IL & Yasuni-Pastaza & Ecuador & 821.108 \\
\hline Yasuni & National Park & $\mathrm{SP}$ & Yasuni-Pastaza & Ecuador & 1.027 .300 \\
\hline Matses & National Park & SU & Yavari-Samiria & Peru & 422.544 \\
\hline Nanay-Chambira-Pintayacu & State Park & SU & Yavari-Samiria & Peru & 954.635 \\
\hline Pacaya Samiria & National Park & SU & Yavari-Samiria & Peru & 2.181 .296 \\
\hline Tamshiyacu Tahuayo & State Park & SU & Yavari-Samiria & Peru & 421.731 \\
\hline Yavari Tapiche & Indigenous Land & IL & Yavari-Samiria & Peru & 1.170 .286 \\
\hline
\end{tabular}




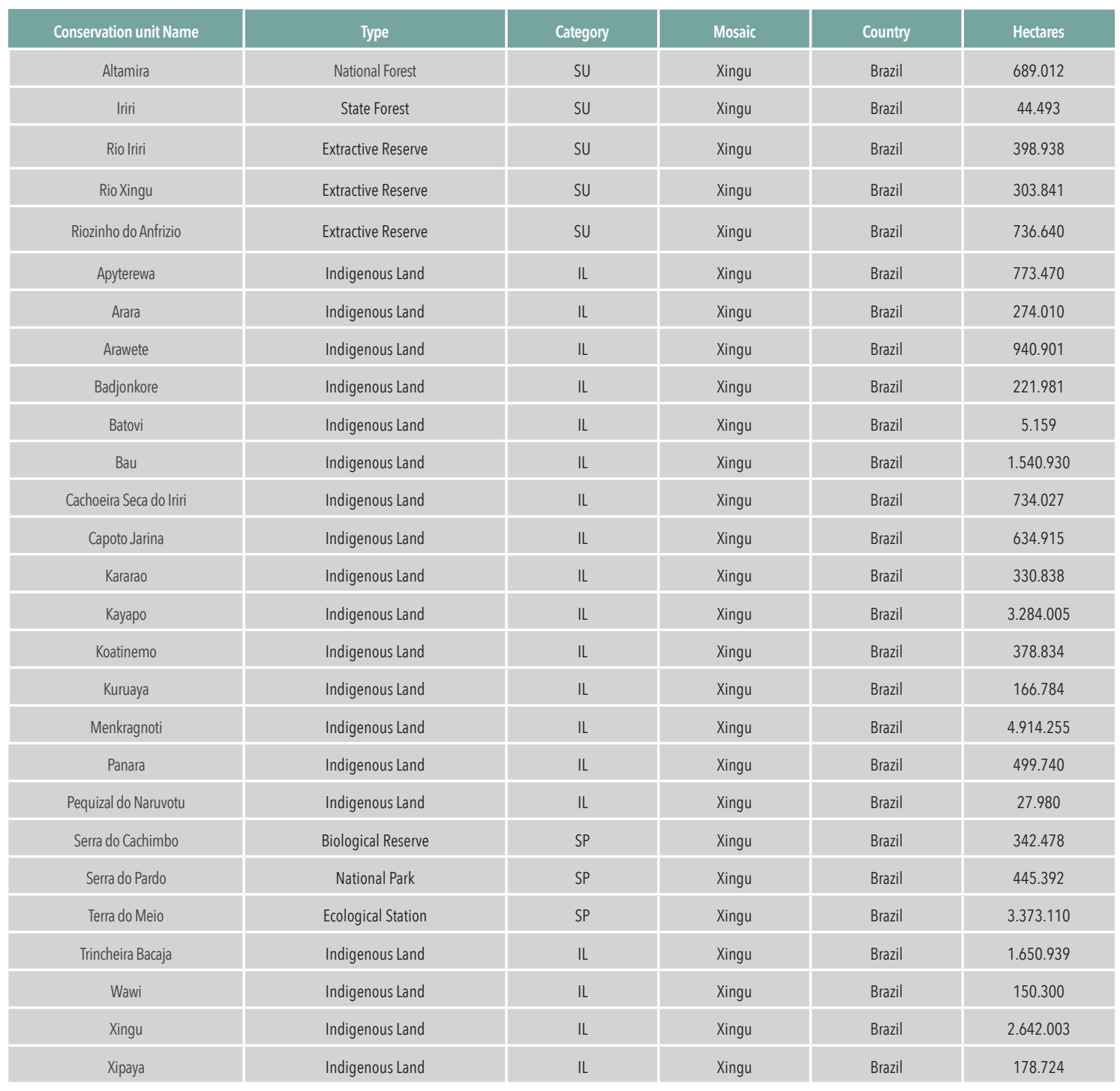





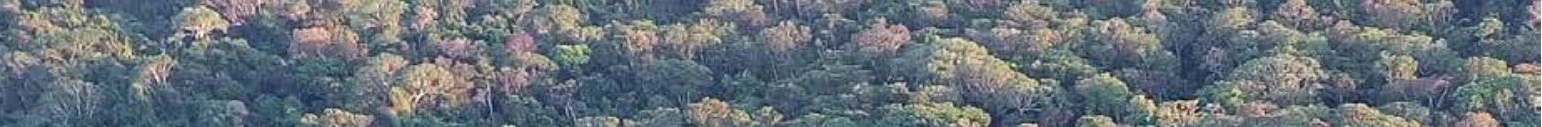

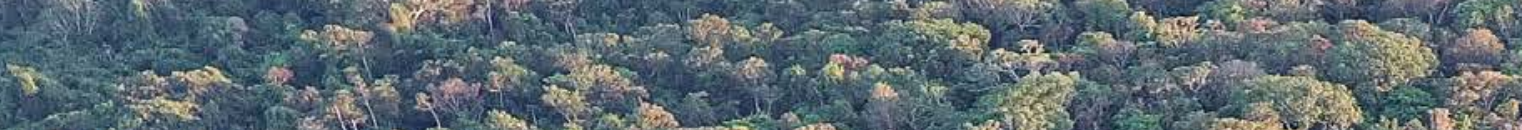

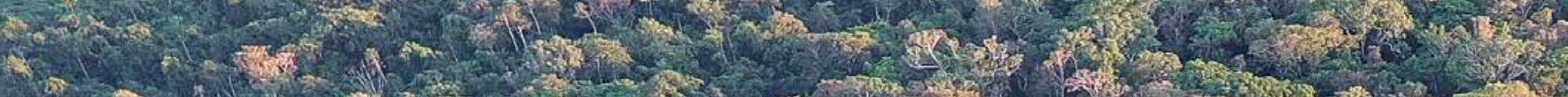

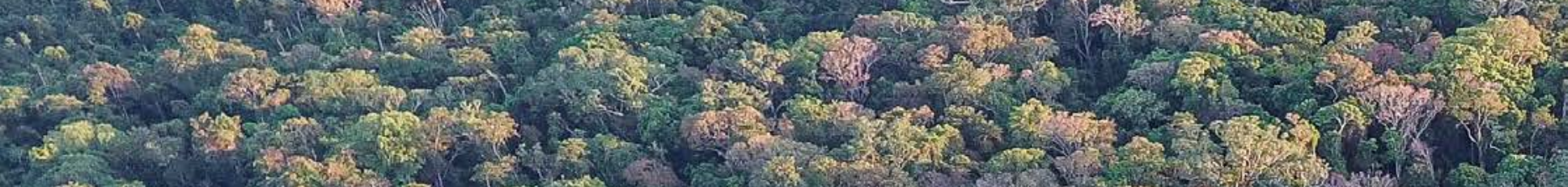

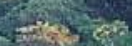
s.
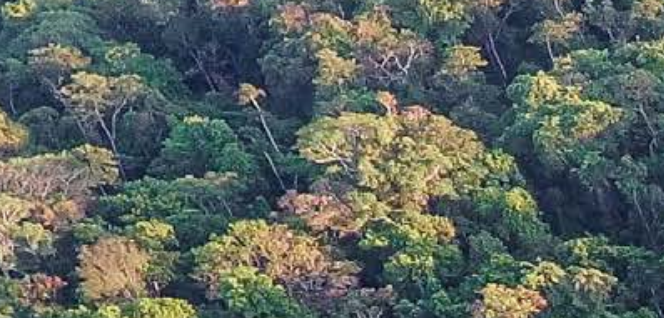

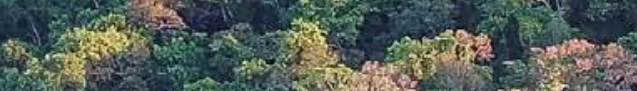

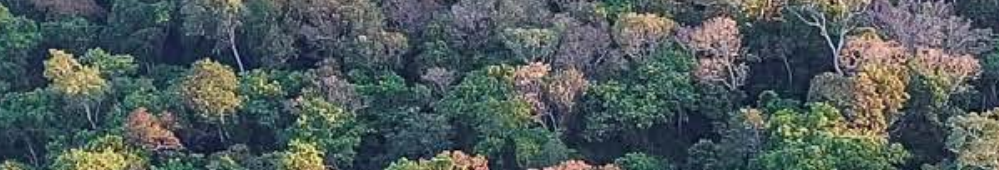
$2+2.2$

$-2 x^{2} \times 5+3$

$43, x^{3}+2+2$

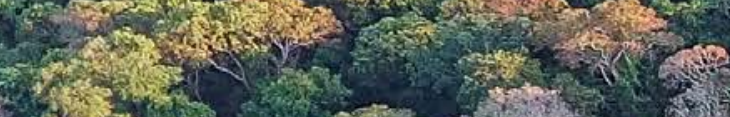

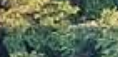

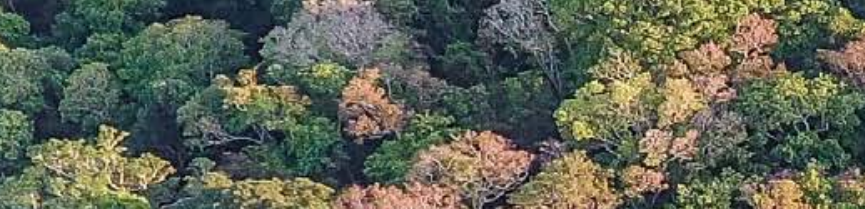
37 m.

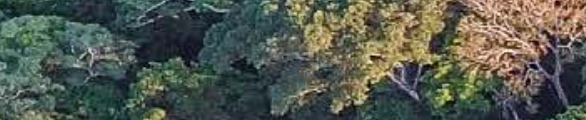

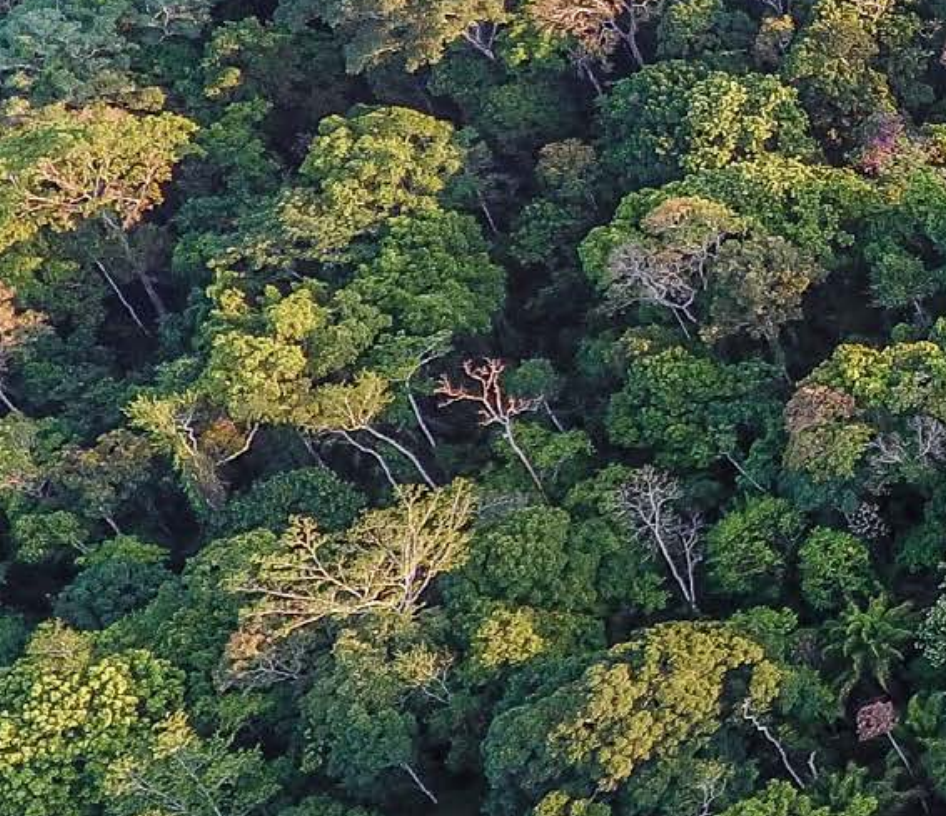
- $107 x^{3}$ $x+3,45$

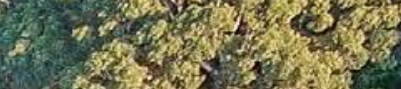

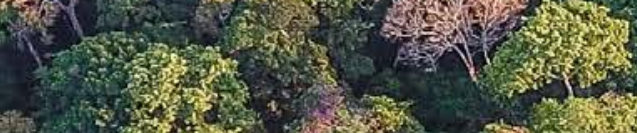

(2) 